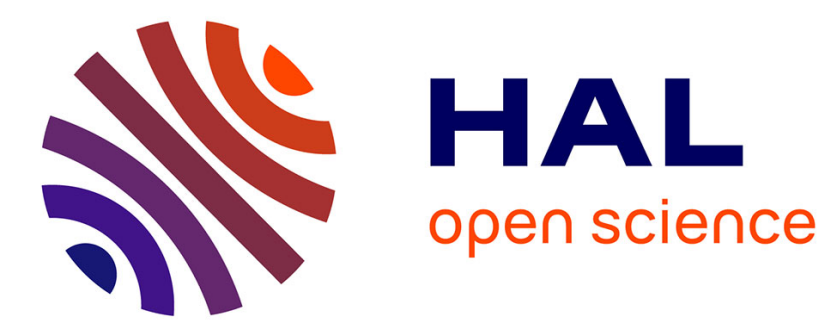

\title{
Petrogenesis of South Armorican serpentinized peridotites
}

Geoffrey Aertgeerts, Jean-Pierre Lorand, Christophe Monnier, Carole La

\section{To cite this version:}

Geoffrey Aertgeerts, Jean-Pierre Lorand, Christophe Monnier, Carole La. Petrogenesis of South Armorican serpentinized peridotites. Lithos, 2018, 314-315, pp.100-118. 10.1016/j.lithos.2018.05.013 . hal-02183098

\section{HAL Id: hal-02183098 \\ https://hal.science/hal-02183098}

Submitted on 15 Jul 2019

HAL is a multi-disciplinary open access archive for the deposit and dissemination of scientific research documents, whether they are published or not. The documents may come from teaching and research institutions in France or abroad, or from public or private research centers.
L'archive ouverte pluridisciplinaire HAL, est destinée au dépôt et à la diffusion de documents scientifiques de niveau recherche, publiés ou non, émanant des établissements d'enseignement et de recherche français ou étrangers, des laboratoires publics ou privés. 


\title{
$5 \quad$ Petrogenesis of South Armorican serpentinized peridotites
}

\author{
Geoffrey Aertgeerts ${ }^{1,2}$, Jean Pierre Lorand ${ }^{1 *}$, Christophe Monnier ${ }^{1}$ and \\ Carole $\mathrm{La}^{1}$
}

101 : Laboratoire de Planétologie et Géodynamique à Nantes (LPG) CNRS UMR6112, Université de Nantes, Faculté des Sciences et Techniques

2 Rue de la Houssinière - BP 9220844322 NANTES CEDEX 3 - France

$2:$ Bureau de recherches géologiques et minières (BRGM).

DAT/OMR/GUY/CAY, B.P. 10552, 97333 Cayenne Cedex 2 - France

$15 *$ : Corresponding author (jean-pierre.lorand@univ-nantes.fr) 
20 Abstract Twenty three serpentinite samples collected from five outcrops in south Brittany (Audierne near Quimper, Champtoceaux near Nantes), western France, were studied using optical microscopy, electron microprobe (EMP), inductively-coupled optical emission spectroscopy (ICP-OES), inductively-coupled plasma mass spectrometry (ICP-MS), and laser ablation-inductively coupled plasma mass spectrometry (LA-ICPMS). Their bulk-rock major 25 and trace element contents recomputed on an anhydrous basis are broadly characteristic of mantle-derived peridotites, as are the covariation trends of inert elements despite evidence of serpentinization-related remobilization of some fluid-mobile elements (FME; e.g., Ca, La, Ce, Sr, U). One outcrop near Champtoceaux shows fertile lherzolite compositions and chondritenormalized rare earth element patterns consistent with low (5-7\%) degree of mantle partial 30 melting. The other four occurrences are harzburgites displaying higher partial melting degrees (15-25\%). Regardless of their degree of fertility, our South Armorican peridotites bear evidence of high-temperature melt/fluid - rock metasomatic interaction yielding an overall enrichment in highly incompatible elements (HIE; Cs, Rb, Ba, Th, U, Pb, La). Hydrous modal metasomatism has been identified in both lherzolites and harzburgites. The lherzolites reacted 35 with HIE-enriched small-volume fluids at $\mathrm{P}=1.5-2 \mathrm{Gpa}$ for $\mathrm{T}>900^{\circ} \mathrm{C}$ that produced a Ti-poor pargasite. The Audierne harzburgites were pervasively refertilized by alkali-rich hydrous melts that precipitated $\mathrm{K}$ - and Cr-rich pargasite. Taken as a whole, South Armorican peridotites record a great diversity of protoliths, from supra-subduction zone ophiolites (Audierne) to arcfore arc provenance. 


\section{Introduction}

Serpentinized peridotites are widespread at plate boundaries, whether exposed in midocean ridges, in collision zones or in transcurrent faults (Mével, 2003; Deschamp et al., 2013

45 and references therein). Serpentinized peridotites also crop out in the Armorican massif (western France) especially in the southern part of the massif that comprises the major suture zone between Gondwanian terranes and the Armorica microplate according to geodynamic models of the Variscan orogeny (Ballèvre et al., 2009, 2014; Faure et al., 2009 and references therein). This area from Brest to Nantes known as the South Armorican Domain shows a series

50 of nappe-stacking complexes composed of high-pressure metamorphic rocks (eclogites; blue schists) and mafic/ultramafic rocks (amphibolites, metagabbros, peridotites), within metasedimentary/acid metamorphic rocks. Review papers on the Armorican massif interpreted these serpentinized peridotites as pieces of subducted and obducted oceanic lithosphere (the so-called Galice - Massif Central ocean) tectonically thrust along with remnants of continental

55 margins during the early eo-Variscan event of the Variscan orogeny (Ballèvre et al. 2009; 2014; Faure et al., 2005, 2009). However, no detailed petrological study has ever been performed on these serpentinites that bear evidence of crustal deformation and locally strong weathering, in addition to being poorly exposed as discontinuous, small-size outcrops (Marchand et al., 1969, 1989; Béchennec et al., 1999; Aertgeerts et al., 2015). Their exact 60 origin (mantle-derived tectonites or cumulate peridotites) thus remains unknown.

Our study focused on five occurrences of South Armorican (SA) peridotites from the Champtoceaux (near Nantes) and Audierne (80 km south of Brest, Finistère) nappe-stacking complexes. We performed a multiscale petrological study coupling thin section study by optical microscopy, electron microprobe analyses (EMPA), bulk-rock analyses of major and 
65 trace elements by inductively-coupled plasma mass spectrometry (ICP-MS) and in-situ analyses of preserved minerals by laser ablation-ICPMS (LA-ICPMS). It is well known that geochemical signatures recorded in serpentinites are a complex combination of protolith partial melting, melt-rock interaction history, and serpentinization conditions (Deschamps et al., 2013; Cooperdock et al., 2018 and references therein). Some major elements $\left(\mathrm{CaO}, \mathrm{SiO}_{2}\right.$,

$70 \mathrm{MgO}$ ), and light REE (LREE) can be mobilized during serpentinization and should be interpreted with caution (Paulick et al., 2006; Snow and Dick, 1995) while strong enrichment in fluid-mobile elements (FME; e.g., B, Li, Cl, As, Sb, Pb, U, Cs, Sr, Ba) may occur. All this secondary remobilization may alter the petrogenetic features of pre-serpentinization processes. Our first aim was therefore to unravel any potential alteration of protolith mineral assemblages

75 by serpentinizing fluids. Our second goal was to provide tighter constraints on putative protolith compositions by identifying petrogenetic processes that typically occur in the upper mantle, such as partial melting events and fluid/melt-rock interactions (metasomatism).

\section{Geological setting}

The Armorican massif was structured into seven tectonometamorphic domains during the Variscan collision between Gondwanian terranes and the Armorica microplate (Ballèvre et al., 2009, 2014 and references therein). Each of these seven domains is separated from its neighbors by shear zones of regional extent that are interpreted as major suture zones (Fig. 1). The Champtoceaux Complex extends all over the northeastern area of Nantes, in the Nantes

85 Variscan Domain (NVD) that is limited to the south by the South Armorican Shear Zone (SASZ) and to the north by the Nort-sur-Erdre fault (NEF) (Fig. 1A). The Champtoceaux 
Complex is interpreted as a nappe-stacking structure thrust onto mica schists of late proterozoïc ages (Mauges Unit) during the early eo-Variscan event of the Variscan orogeny and subsequently twisted by the dextral movement of the SASZ (Ballèvre et al. 2014). From 90 bottom to top, the Champtoceaux complex is composed of three structural units, a lower allochton, a middle allochton and an upper allochthnon, each one being separated by thrust faults (Fig. 1A). The lower allochthon unit consists of Ordovician orthogneisses (485 Ma; Paquette et al. 1984) enclosing eclogite lenses (Ballèvre et al. 2002) and garnet-chloritoidchlorite-mica schists with high-pressure metasedimentary relicts (Pitra et al. 2010). Felsic 95 rocks are thought to represent pieces from the northern margin of the Gondwana megacontinent (Ballèvre et al. 2009, 2014; Pitra et al. 2010). In more detail, the Cellier formation and Ordovician orthogneisses is overlain by garnet-staurolite-biotite micaschists of the Saint-Mars-du-Désert formation (Pitra et al. 2010). The middle allochthon unit is made up of amphibolites (Folie Siffait amphibolites). The upper allochthon (Champtoceaux formation)

100 is an orthogneiss unit with eclogitic relics representing the southern margin of the Armorica microplate (Bosse et al. 2000; Ballèvre et al. 2009, 2014; Pitra et al. 2010). The Champtoceaux formation is overthrust by a younger (?) composite unit comprising the Drain formation (metagabbros of N-Type MORB affinity, mafic cumulates (Paquette et al., 1984) and serpentinites (Ballèvre et al. 2013)), the Le Hâvre formation (mica schists containing graphite105 rich siliceous rocks known as "phtanites") and Pont de Barel formation (Fig. 1A). This latter crops out in the northwestern part of the Champtoceaux complex, in tectonic contact with the le Hâvre micaschists.

The Audierne Complex is located in the westernmost part of the Armorican Massif, near Quimper, $80 \mathrm{~km}$ to the south of Brest, in the South Armorican Domain (Fig. 1B). It is 
110 described in geological maps as a remnant of an ophiolitic complex, itself subdivided into the Audierne unit and the Trunvel-Tréogat unit (Plaine et al. 1981; Béchennec et al. 1999; Cagnard 2008). The northern part of the Audierne unit is composed of serpentinites (Ty-lan serpentinites) whereas the southern part consists of metagabbros and amphibolites (Peumerit formation) displaying N-MORB affinities (Bernard-Griffiths and Cornichet 1985; Béchennec

115 et al. 1999). A few chromitite occurrences were recognized inside the Peumerit formation, but their field relationships with surrounding rocks are unknown (BRGM, «Mineralogical Inventory of Finistère», 1975). The Trunvel-Tréogat unit consists of amphibolites in its northern part (Tréogat formation) and mica schists in its southern part (Trunvel formation). To the north, the Trunvel-Treogat formation is overlain by the Penhors formation, the

120 southernmost continental margin of the Armorica microplate according to Ballèvre et al. (2014).

\section{Sampling}

The 23 serpentinites studied were collected from Ty Lan outcrop in the Audierne complex (10 samples) and four outcrops throughout the Champtoceaux complex (Fig. 1A),

125 i.e., Folies Siffait from the middle allochthon unit, Le Havre Fomation (l'Orgerais serpentinites), Pont-de-Barrel formation and Drain formation (Butte de la Roche) from the Champtoceaux unit. The Folies Siffait serpentinites were sampled in a $50 \mathrm{~m}^{2}$ outcrop near the small town of Oudon along the Loire river bank (Fig. 1A). The Butte de la Roche serpentinites were sampled 10 kilometers eastward of the city of Nantes from occasional outcrops in the

130 bank of the roads near La Haie-Fouassière. The l'Orgerais serpentinites were sampled in a small carry between Blain and Heric, not far from the tectonic contact with the late carboniferous pull-appart sedimentary basin of Ancenis (Fig. 1A). The Pont de Barel 
serpentinites were sampled in an amphibolite quarry that exposes a $50-60 \mathrm{~m}^{2}$ outcrop of peridotites near the small village of Saint Omer de Blain.

Thin sections and rock powders were done from the carbonate-free interiors of serpentinized blocks, previously cleaned up from any supergene alteration product. These serpentinite cores consist in pseudomorphic, retrogressive lizardite + magnetite + chrysotile assemblages (Aertgeerts et al, 2015). At Folie Siffait and L'Orgerais, this assemblage was partly overprinted by a high stress, low-temperature deformation that generated mylonitic to

140 ultramylonitic microtextures. In addition to pseudomorphic serpentinization assemblages, all Champtoceaux and Ty Lan serpentinites display various generations of chrysotile, from ubiquitous crack-seal veins penetrating deeply into serpentinite blocks (e.g. Pont de Barel) to chrysotile fiber veins contemporaneous to the penetrative deformations in L'Orgerais serpentinites.

\section{4. Analytical methods}

Thin sections were studied with an optical polarizing microscope, using transmitted and reflected light. The few minerals predating serpentinization (olivine, Cr-spinel, pargasite, see below) were analyzed with a CAMECA SX-100 electron microprobe at the Service Microsonde Ouest of Brest University. The analytical conditions for silicates and oxides were:

150 accelerating voltage $15 \mathrm{kV}$, sample current $20 \mathrm{nA}$, beam diameter $1 \mu \mathrm{m}, 10$ s peak counting and 5 s background counting on either side of the peaks. Elemental concentrations were determined using both natural and synthetic compounds. A complete data set is given in supplementary data (Table S1, S2 and S3)

Major elements were analysed with a iCAP-6300 Thermo inductively-coupled plasma 
155 optical emission spectrometer (ICP-OES) at the "Laboratoire de Planétologie et Géodynamique" (LPG) in Nantes. Each sample was crushed and powdered in an agate ring mill. The amount of sample powder was typically $125 \mathrm{mg}$, which were placed into Savillex beakers along with 0.5 milliliters of distilled concentrated $\mathrm{HNO}_{3}(65 \%)$ and 40 drops of distilled concentrated HF. Savillex beakers were left dissolving overnight at $110^{\circ} \mathrm{C}$. After cooling, the solution was transferred into a $100 \mathrm{ml}$ bottle along with with $5 \mathrm{~g}$ of external standard solution (Ge $80 \mathrm{ppm}$, Co $80 \mathrm{ppm}$ ). $20 \mathrm{~g} / \mathrm{l}$ of boric acid was added to neutralize hydrofluoric acid and the solution was left for another 48 hours. Elemental concentrations were determined with international rock standards JP-1, BIR-1, WS-E, W-2, and PM-S as external calibration standards. Trace elements were analysed with a VARIAN 820MS inductively-coupled plasma mass spectrometer (ICP-MS). Solutions were prepared by dissolving $125 \mathrm{mg}$ of sample powder in clean Savillex TM beakers, using $0.5 \mathrm{ml}$ of milliQ water, $0.5 \mathrm{ml}$ of bi-distilled $\mathrm{HNO}_{3}$ (65\%), 14 drops of bi-distilled $\mathrm{HF}(40 \%)$ and 3 drops of distilled perchloric acid $\mathrm{HClO}_{4}(70 \%)$. This mixture was left overnight on a hotplate at $130^{\circ} \mathrm{C}$ and then evaporated at $110^{\circ} \mathrm{C}$ for 5 170 hours and at $120^{\circ} \mathrm{C}$ for 4 hours. The residuum was dissolved by the same protocol and left on an hotplate at $130^{\circ} \mathrm{C}$ for 48 hours. Then $1 \mathrm{ml}$ of bi-distilled $\mathrm{HNO}_{3}(65 \%)$ was added and the solution left on a hotplate at $120^{\circ} \mathrm{C}$ for 72 hours. After evaporation at $130^{\circ} \mathrm{C}$ for 12 hours, the residuum was dissolved with $1 \mathrm{ml}$ of bi-distilled $\mathrm{HNO}_{3}(65 \%)$ at $110^{\circ} \mathrm{C}$ for 5 hours. The solution was then transferred into a $250 \mathrm{ml}$ bottle weighed on a balance along with $50 \mathrm{~g}$ of $5 \%$

$175 \mathrm{HNO}_{3}$ internal standard solution (10 ppb Ge, 4ppb Rh-In-Tm-Bi) and then adjusted to $250 \mathrm{~g}$ by 
adding Milli Q water. Internal standard solution was used to correct for linear drift and matrix effect.

Analyzed isotopes and operating parameters for the ICP-MS are given in Table S5 (supplementary data). Elemental concentrations were determined with three international rock 180 standards UB-N, JP-1 and BIR-1. Limits of detection are given Table 1. Precision and accuracy of solution ICP-MS analyses of major and trace element concentrations at LPG were tested against two peridotite reference materials (UB-N and JP-1) analysed as unknown. Our results agree within recommended values at 1 sigma level (Table 1).

Because it was mostly preserved from serpentinization (see below), amphibole was 185 analysed by laser ablation inductively coupled plasma mass spectrometry (LA-ICPMS) at LPGN. The samples were ablated and collected using a Photon Machine Analyte G2 pulsed 193-nm ArF Excimer laser coupled with a VARIAN 820 quadrupole ICPMS system. The Photon Machine laser is equipped with a dual volume sample cell that keeps the sample volume small. Laser sampling was performed in an Ar atmosphere with $\mathrm{He}-\mathrm{H}_{2}$ (ratio 15:1) as

190 a carrier gas with homogeneous beam diameters $(85-110 \mu \mathrm{m}) .{ }^{29} \mathrm{Si}$ was used as internal standard and NIST SRM 612 glass as external standard with reference values from Jochum et al. (2011). An in-house secondary standard (gem quality diopside from Madagascar previously analysed via solution ICPMS and LA-ICPMS in a set of laboratories from abroad) was included as an unknown during the analytical runs to test accuracy and reproducibility of

195 LPGN in-situ analyses (Table S6). Our values generally agree within 10\% with working values except for $\mathrm{Ba}$ and $\mathrm{Sr}$ data which were not reproduced. By contrast, both elements were detected in significant amounts in our samples . 


\section{Mineralogy}

Despite extensive serpentinization and secondary mylonitic deformation in L'Orgerais and Folies Sifait occurrences, pre-serpentinization rock textures and high-temperature minerals can be recognized as well as variations in the original mineralogy between each of the five peridotite outcrops studied here.

Ty Lan samples are spinel- and opx-bearing peridotite (harzburgites) showing an

205 overall coarse-grained texture. Olivine porphyroclasts up to several $\mathrm{mm}$ across can be identified (Fig. 2A). Those preserved olivines show a few kink banding with well spaced subgrain boundaries indicating high-temperature recristallisation (Mercier and Nicolas, 1975). Cr-spinel occurs in-between or inside olivine grains as strongly euhedral, small-sized brownish grains (usually $<200 \mu \mathrm{m}$ across) sometimes showing octahedral cross-sections; larger,

210 ameboidal spinels are almost lacking. Cr-spinel is systematically replaced by porous ferritchromite (reflected-light microscopy data) and always surrounded by a 100-200 $\mu$ m-thick chlorite corona which may locally replace the spinel (e.g. TGA341 D). Orthopyroxenes (now totally replaced by Al-rich bastites) occur as very small ovoid grain within the olivine matrix. Ty Lan peridotites show 10-15 vol. \% (visual estimate) of rounded, sometimes twinned

215 crystals (up to $300 \mu \mathrm{m}$ across) of colourless amphibole devoid of undulose extinction under cross-polariser transmitted light (Fig. 2A). This amphibole may form discontinuous layers inside olivine-rich lithologies or polycristalline amphibole networks resulting from the recrystallization of larger grains. No specific association with Cr-spinel has been observed. Another secondary amphibole (identified as tremolite by EMPA) may also be observed as 220 truncated prismatic crystals. 
Champtoceaux peridotites as a whole show pre-serpentinization mineralogy of harzburgites. The Pont-de-Barel samples are rich in small-sized bastites $(<500 \times 200 \mu \mathrm{m})$ characterized by convex-inward grain boundaries. Cr-spinel (3-5 vol.\%, visual estimate) occurs as both ameboidal grains, up to $500 \mu \mathrm{m}$ in maximum dimension, and rare smaller (200 $225 \mu \mathrm{m}$ across at best), subequant grains. Both Cr-spinel occurrences preserved greenish to brownish core surrounded by an opaque ferritchomite and/or magnetite rim (Fig. 2D). No clinopyroxene, nor olivine, was identified, even in the least altered sample (TGA007C). By contrast, Pont-de-Barel harzburgites are rich in colourless amphibole (up to $10 \%$ by vol.) crystallized as large, undeformed, often euhedral, twinned or elongated crystals; amphibole230 spinel-bastite clusters are common and amphibole preserving spinel inclusions or bastite cores have been observed (Fig. 2B,C).

At Butte de la Roche, harzburgites display common, small-sized bastitized orthopyroxene, often associated with ameboidal Cr-spinel. This latter may now be totally replaced by serpentinization-derived magnetite and chlorite. At l'Orgerais, due to the 235 secondary mylonitic deformation, spinel harzburgites exhibit elongated bastites porphyroclasts ( $>1 \mathrm{~mm}$ in maximum dimension) showing undulose extinction under crossed-polarizer transmitted light. Cr-spinel occurs as abundant large, reddish translucent ameboidal grains up to $500 \mu \mathrm{m}$ in maximum dimensions (Fig. 2 E,F). Ferritchromite or magnetite overgrowths are not rare (reflected light microscopy data) but unaltered spinel cores were mostly preserved.

Despite secondary penetrative foliation, olivine relics are surprizingly common in Folie Siffait harzburgites (Fig. 2G). It is devoid of undulose extinction or kink banding. Restitic olivine grains may preserve the same orientation through lizardite mesh textures, suggesting a millimetric size for the original olivine grains. No preserved pyroxene was identified but 
orthopyroxene bastites are common (Fig. 2H), Bastites are either globular grains, up to $500 \mu \mathrm{m}$

245 in diameter, immersed in olivine matrix, or tabular crystals associated with relict magnetite and/or serpentinized olivine. Such associations, up to $2 \mathrm{~mm}$ in maximum dimensions are pervasively penetrated by lizardite. No ameboidal nor equant spinel can be identified, which may be due to the high amount of chlorite in this occurrence. Colourless, undeformed secondary amphibole crystals (identified as tremolite by EMPA) are widespread (up to 10-20\% 250 by vol.).

\section{Mineral chemistry}

\subsection{Olivine}

Olivine compositions range from $\mathrm{Fo}_{89}$ for Folie Siffait olivines to $\mathrm{Fo}_{90}$ for Ty Lan 255 olivines. Both show high $\mathrm{NiO}$ contents $(0.27-0.42 \mathrm{wt} \%)$, within the compositional range of mantle-derived peridotites (Table S1).

\subsection{Cr-spinel}

Pont de Barel Cr-spinels are Al-rich $(0.07<\mathrm{Cr} \#<0.15 ; \mathrm{Cr} \#=\mathrm{Cr} / \mathrm{Cr}+\mathrm{Al}$ (atomic percentages)) while the L'Orgerais deep-red ameboidal $\mathrm{Cr}$-spinels are $\mathrm{Cr}$-rich $(\mathrm{Cr} \#=0.45$ -

260 0.67), as are Butte de la Roche spinels ( $\mathrm{Cr} \#=0.33-0.54$; Fig. 3; Table S2). Their Mg\# $(\mathrm{Mg} / \mathrm{Mg}+\mathrm{Fe}$ (atomic percentages)) decreases from $0.65-0.73$ in PdB spinels to $0.48-0.54$ for l'Orgerais spinels. This negative correlation between $\mathrm{Cr} \#$ and $\mathrm{Mg \#}$ has been widely documented in mantle peridotites as a whole (e.g. Arai, 1994; Niu, 1997; Hellebrandt et al., 2001; Pearson et al., 2014 and ref. therein). However, south Armorican peridotites show Fe- 
265 enriched $\mathrm{Cr}$-spinel compositions compared to abyssal peridotites. $\mathrm{TiO}_{2}$ and trivalent iron contents are low $\left(<0.1\right.$ wt. $\%$; $\left.\mathrm{Fe}^{3+} / \mathrm{Fe}^{3+}+\mathrm{Al}^{3+}+\mathrm{Cr}^{3+}=0.01-0.05\right)$. L'Orgerais and Butte de la Roche spinels are poorer in $\mathrm{NiO}$ compared to PdB spinels ( $<0.1$ vs. $0.25-0.39 \mathrm{wt} \%)$.

\subsection{Amphibole}

Porphyroclastic colorless amphibole from Pont-de-Barel and Ty Lan peridotites are 270 low-Ti $(\mathrm{Ti}<0.1$ at. p.f.u.), low-K $(<0.12$ at. p.f.u.) Cr-bearing magnesian pargasites $(\mathrm{Mg}$ number $(100 \times \mathrm{Mg} / \mathrm{Mg}+\mathrm{Fe}$ (atomic percentages $))=87-90)$ characterized by tetraedral $\mathrm{Al}$ predominating over octaedral $\mathrm{Al}\left(1.6<\mathrm{Al}^{\mathrm{IV}}<1.8\right.$ (atom per formula unit); $0.32<\mathrm{Al}^{\mathrm{VI}}<0.63$ ) and incompletely filled A sites (Table S3; Fig. 4). Both are slightly nickeliferous $(\mathrm{NiO}=0.1$ wt.\%). Pont-de-Barel pargasites show higher extent of richteritic substitution $\left({ }^{\mathrm{B}} \mathrm{Ca}_{-1}{ }^{\mathrm{AV}}-{ }^{\mathrm{B}} \mathrm{Na}_{1}{ }^{\mathrm{A}} \mathrm{Na}_{1}\right)$ and 275 are Ti- and $\mathrm{Al}^{\mathrm{IV}}$ - richer. Ty Lan pargasitic hornblende are $\mathrm{K}$ - and Cr-richer (Fig. 5).

\section{Whole-rock geochemistry}

\subsection{Major Elements}

Our south Armorican peridotites show L.O.I values (11.5-15 wt.\%) close to the observed values for theoretical serpentine minerals (average of 12.38 wt.\%.; Deschamps et al., 2013), in agreement with petrographic data. There is no correlation between L.O.I. and $\mathrm{CaO}$ contents, which rules out a significant contribution of carbonates (Table 1). Taken as a whole, the bulk-rock analyses correspond to peridotites in the $\mathrm{SiO}_{2} / \mathrm{MgO}$ vs. $\mathrm{Al}_{2} \mathrm{O}_{3}$ plot of Fig. $6 \mathrm{~A}$. Our peridotites plot well within the compositional field of abyssal peridotites $(0.01<$ $\left.\mathrm{Al}_{2} \mathrm{O}_{3} / \mathrm{SiO}_{2}<0.075 ; 0.75<\mathrm{MgO} / \mathrm{SiO}_{2}<1.05 ; \mathrm{Niu}, 2004\right)$. These rock produce a trend of 
produced by melting processes (Fig. 6B). Pont-de-Barel peridotites are clearly less depleted $\left(0.06<\mathrm{Al}_{2} \mathrm{O}_{3} / \mathrm{SiO}_{2}<0.07\right)$ compared to the four other harzburgitic outcrops studied. These latter plot inside the compositional field of serpentinised abyssal harzburgites whereas Pont de Barel peridotites are closer to UB-N, a serpentinized lherzolitic international rock standard. also plot within the field of abyssal peridotites and their serpentinised analogs. Taken as a whole, they are variably enriched in $\mathrm{FeO}$ compared to the terrestrial mantle melting arrays (Fig. 7A). However, their Mg numbers (89-91) are consistent with a mantle-derived origin (Workman and Harte, 2005; Bodinier and Godard, 2014 and references therein). Two Butte de (84-87) compared to mantle values. This $\mathrm{MgO}$ depletion trend operates with increasing $\mathrm{MgO}$. One sample (TGA018J) clearly falls out of the field of abyssal peridotites of Niu (2004) in both parts of Fig. 7, yet Deschamp et al:-, (2013) reported few FeO-rich abyssal serpentinites.

South Armorican peridotites span a large range of variation in the $\mathrm{CaO}$ vs. $\mathrm{MgO}$ plot of 300 Fig. 7B. The Pont de Barel fertile samples along with one Ty Lan pargasite-rich sample (TGA346B) show the highest $\mathrm{CaO}$ contents. L'Orgerais harzburgites, and one $\mathrm{Ty}$ Lan $\mathrm{Al}_{2} \mathrm{O}_{3^{-}}$poor harzburgite TGA343A are strongly Ca-depleted compared to the other samples.

\subsection{Trace Elements}

Transition element concentrations plot well within the published mantle arrays in Fig. 8. There is no clear correlation between $\mathrm{Ni}$ (or Co) and $\mathrm{Al}_{2} \mathrm{O}_{3}$ (Fig $\left.8 \mathrm{~A}, \mathrm{~B}\right)$. Variations in spinel modal contents and/or compositional variations in this mineral (including those resulting from transformation into ferrichromite) can account for some outliers in the $\mathrm{Cr}$ vs. $\mathrm{Al}_{2} \mathrm{O}_{3}$ plot of Fig. 
8C. Incompatible transition metals $\left(\mathrm{Ti}, \mathrm{V}, \mathrm{Sc}\right.$ ) broadly correlate positively with $\mathrm{Al}_{2} \mathrm{O}_{3}$ : the Butte de la Roche Fe-rich samples display coupled enrichment in Fe, Ti, V and Cr (Fig. 8D to F).

South Armorican peridotites show incompatible trace element $($ ITE $=$ Rare Earth Elements - REE, large ion lithophile elements - LILE, and high field strength elements HFSE) spreading over the whole concentration ranges reported for mantle-rock and their serpentinized analogs (Fig. 9, 10). The samples studied are variably depleted in heavy REE (HREE) compared to MORB mantle source estimates (Workman and Hart, 2005). This HREE

315 depletion degree (2.0 to $0.015 \times$ CI-chondrite) increases in parallel with the $\mathrm{Al}_{2} \mathrm{O}_{3}$ depletion, i.e. from Pont-de-Barel samples to Ty Lan, Folie Siffait and l'Orgerais harzburgites. Middle REE (MREE) and Light REE (LREE) contents do not follow such clear covariation trends with fertility. Pont de Barel and Ty Lan peridotites show high but variable LREE concentrations ( $\mathrm{La}_{\mathrm{N}}$ up to $6 ; \mathrm{N}=\mathrm{CI}$-chondite normalized) compared to published data for mantle peridotites. Pont-de-Barel samples display nearly flat CI chondrite-normalized patterns with moderate LREE enrichments $\left(\mathrm{La}_{N} / \mathrm{Sm}_{\mathrm{N}}=1.3-4.2\right)$ that have been reported mainly from weakly metasomatized continental orogenic lherzolites (Fabriès et al., 1991, 1998; Bodinier and Godard, 2004). Ty Lan peridotites show negatively trending CI-chondrite normalized patterns coupling strong LREE- and MREE-enrichments $\left(\mathrm{La}_{\mathrm{N}} / \mathrm{Sm}_{\mathrm{N}}=2.7-5.6 ; \mathrm{Sm}_{\mathrm{N}} / \mathrm{Yb}_{\mathrm{N}}=1.3-\right.$

325 5.9) with HREE depletion $\left(0.38<\mathrm{Yb}_{\mathrm{N}}<1.09\right.$; Fig. 9). Such patterns have been documented only in very metasomatised continental orogenic peridotites (e.g. Caussou, Fabriès et al. 1991; Bodinier and Godard, 2014). Taken as a whole, $\mathrm{La}_{\mathrm{N}} / \mathrm{Yb}_{\mathrm{N}}$ increases at decreasing HREE contents. The Folie Siffait harzburgites exhibit spoon-shaped REE patterns $\left(\mathrm{La}_{N} / \mathrm{Sm}_{N}=1.80\right.$; $\left.\mathrm{Yb}_{\mathrm{N}}=0.87\right)$ while $\mathrm{V}$-shaped REE patterns characterize the l'Orgerais harzburgites $\left(\mathrm{La} / \mathrm{Sm}_{\mathrm{N}}=\right.$ 4.4-6.3; $\left.\mathrm{Sm}_{\mathrm{N}} / \mathrm{Yb}_{\mathrm{N}}=0.55\right)$. Such patterns were documented in many mantle-derived 
harzburgites, whether orogenic, ophiolitic or abyssal harzburgites (Deschamp et al., 2013; Bodinier and Godard, 2014; Fig. 9). The most striking difference with abyssal harzburgites is the lack of positive Eu* anomalies. Note that the three Butte de la Roche Fe-rich harzburgites display abnormally high REE concentrations compared to their low bulk-rock $\mathrm{Al}_{2} \mathrm{O}_{3}$ contents $335\left(\mathrm{Yb}_{\mathrm{N}}=1.5 \times \mathrm{CI}\right.$-chondrites; $\mathrm{La}_{\mathrm{N}} / \mathrm{Sm}_{\mathrm{N}}=1.5-2.02 ; \mathrm{Sm}_{\mathrm{N}} / \mathrm{Yb}_{\mathrm{N}}=1-2.6$; Fig 9). Yttrium, a proxy of HREE, is also significantly enriched compared to the other analyzed samples (Table 1).

In addition of being LREE-enriched, South Armorican peridotites are variably enriched in LILE, i.e. Cs (4-80 x PM), Rb (0.3-3 x PM); Ba (0.4-4 x PM), Th (0.1-2.2 x PM) and U (0.4-100 x PM), where PM = Primitive Mantle)(Fig. 10). Despite some variability within a 340 single occurrence, $\mathrm{U}_{\mathrm{N}} / \mathrm{Th}_{\mathrm{N}}$ increases from 1.8 in Pont-de-Barel samples to 2.2-6.5 in Ty Lan harzburgites, 3.7 for l'Orgerais harzburgites, 7-22 for Butte de la Roche harzburgites and 59 in Folie Siffait harzburgites ( $\mathrm{N}=\mathrm{PM}$ normalized). The same is also true for $\mathrm{Sr}, \mathrm{Ba}$ and $\mathrm{Pb}$ that all produce positive anomalies in the PM-normalized extended patterns of Fig. 10, with however, some exceptions (e.g. Butte de la Roche for $\mathrm{Pb}$; both negative and positive $\mathrm{Sr}$ anomalies in

345 Pont-de-Barel peridotites). L'Orgerais harzburgites fall closer to the compositional field of mantle wedge serpentinites, or fore-arc serpentinised harzburgites (eg Izu-Bonin harzburgites) that combine extreme $\mathrm{Ba}, \mathrm{Rb}, \mathrm{Cs}, \mathrm{Pb}$ and $\mathrm{Sr}$ enrichment with strong REE depletion (Deschamp et al., 2013; Bodinier et al., 2014). Pont de Barel and Ty Lan samples plot within the field of refertilized abyssal harzburgites in Fig. 10. Ty Lan peridotites show strong negative anomalies 350 of all five HFSE's $\left(3.8<\mathrm{La}_{\mathrm{N}} / \mathrm{Nb}_{\mathrm{N}}<27 ; 0.13<\mathrm{Ti}_{\mathrm{N}} / \mathrm{Gd}_{\mathrm{N}}<0.48\right)$. The same is true for two Butte de la Roche harzburgites $\left(4<\mathrm{La}_{N} / \mathrm{Nb}_{\mathrm{N}}<80\right.$ and $\left.0.11<\mathrm{Ti}_{\mathrm{N}} / \mathrm{Gd}_{\mathrm{N}}<0.58\right)$ (Fig. 10) whereas the Pont-deBarel peridotites are devoid of $\mathrm{Ti}, \mathrm{Zr}$ and $\mathrm{Hf}$ negative anomalies. 


\section{In-situ analyses trace element analyses of pargasite.}

contents in the two amphibole-rich samples from Pont de Barel (TGA007C) and Ty-Lan (TGA346C). (Compare Table S3 and S4). Pargasite is enriched in ITE by a factor 10 compared to the corresponding bulk-rock analyses. Its composition is highly reproducible within a single thin section (relative standard deviation RSD $<10 \%$ for REE). Ty Lan pargasite exhibits

360 LREE-enriched negatively-trending CI-chondrite normalized REE patterns $\left(1.6<\mathrm{La}_{\mathrm{N}} / \mathrm{Yb}_{\mathrm{N}}<4.2\right.$; $4.9<\mathrm{Sm}_{\mathrm{N}} / \mathrm{Yb}_{\mathrm{N}}<7.1 ; \mathrm{N}=\mathrm{CI}$-chondrite) that faithfully reproduce the whole-rock pattern (Fig. 11A). Pont de Barel pargasite displays the same selective LREE enrichment over MREE and HREE as the whole-rock analyses $\left(2.3<\mathrm{La}_{N} / \mathrm{Sm}_{N}<3.5 ; 0.59<\mathrm{Sm}_{N} / \mathrm{Yb}_{\mathrm{N}}<0.67\right)$. The mantlenormalized extended ITE patterns of pargasite also reproduce the whole-rock patterns quite well apart from a strong depletion in Cs, a lack of a positive $U$ anomaly $\left(0.64<\mathrm{U}_{\mathrm{N}} / \mathrm{Th}_{\mathrm{N}}<1.27\right)$, a lack of a $\mathrm{Nb}$-Ta negative anomaly in Ty Lan pargasite, and weaker $\mathrm{Cs}$ and $\mathrm{Sr}$ enrichment $\left(1.7<\mathrm{Sr}_{\mathrm{N}} / \mathrm{Nd}_{\mathrm{N}}<2.4\right)$ coupled with stronger positive $\mathrm{Pb}$ anomalies $\left(4.7<\mathrm{Pb}_{\mathrm{N}} / \operatorname{Pr}_{\mathrm{N}}<5.1\right)$ for Pontde-Barel pargasite.

\section{Discussion}

South Armorican peridotites are mantle-derived peridotites. Their preserved relic

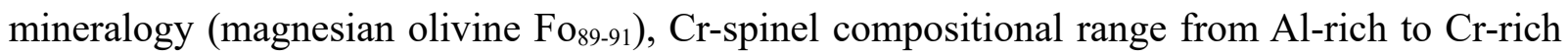
end-members, orthopyroxene replaced by bastite, pargasite), their bulk-rock major element concentrations, and their various trace element patterns are consistent with such an origin. 
of mantle-derived protoliths indicating a combination of different high-temperature processes. Due to our limited sampling and the high degree of alteration, inferences on the lowtemperature mobility of major and trace elements should be made before addressing those high-T mantle processes. It is well known that some major elements and incompatible trace elements can be mobilized during low-temperature serpentinization or high-temperature meltrock interaction and should be interpreted with caution (Coleman, 1967; Paulick et al., 2006; Snow and Dick, 1995; Deschamps et al., 2013). It has long been postulated that serpentinization/ocean floor alteration can modify $\mathrm{MgO} / \mathrm{SiO}_{2}$ (Mével, 2003; Niu, 2004; Frost and Beard, 2007; Ullrich et al., 2010; Harvey et al., 2014). In the Deschamps et al. compilation

385 (2013) of Fig. 6, our serpentinites fall within the oceanic array defined by abyssal peridotites (Bodinier and Godard, 2014; Niu, 2004), which is parallel to the terrestrial array but with lower values in $\mathrm{MgO} / \mathrm{SiO}_{2}$. This worldwide difference between terrestrial array and oceanic array is explained by a loss of $\mathrm{MgO}$ during low-temperature seafloor weathering (Niu, 2004; Snow and Dick, 1995). Concerning our samples, there is no evidence for further $\mathrm{MgO}$ losses or $\mathrm{SiO}_{2}$ gain of regional extent. Our samples preserved Mg numbers values (89-91) consistent with a mantle-derived origin, despite a slight $\mathrm{FeO}$ enrichment compared to the mantle array (Fig. 7A). Only the three Butte de la Roche samples show distinctly lower Mg number in the binary plots of Fig. 7A, with sample TGA018J off the compositional field of mantle peridotites as a whole. However, if pervasive $\mathrm{MgO}$ loss had occurred, it should result in a parallel increase 395 in all of the other element concentrations when recalculated on an anhydrous basis. According to Fig. 7A, the low $\mathrm{MgO}$ of Butte de la Roche samples is balanced by an almost parallel increase in $\mathrm{FeO}$ (in addition to a few trace elements element contents, $\mathrm{V}, \mathrm{Ti}, \mathrm{Cr}, \mathrm{Sc}$ and $\mathrm{REE}$ ). This relationship seems to rule out a low temperature origin for this peculiar geochemical signature. 

(Coleman, 1967; Snow and Dick, 1995; Niu, 2004; Bach and Klein, 2008; Fabriès et al., 1998; Iyers et al., 2008; Austrheim and Prestwick, 2008). Calcium and silicon are interpreted as mobile elements in hot hydrothermal fluids because of clinopyroxene breakdown. L'Orgerais harzburgites, as well as one Ty Lan sample (TGA342A), show a strong depletion in CaO (Fig.

405 7B), with respect to $\mathrm{Al}_{2} \mathrm{O}_{3}\left(0.01<\mathrm{CaO} / \mathrm{Al}_{2} \mathrm{O}_{3}<0.06\right)$ and to the Depleted MORB mantle (DMM) composition $\left(\mathrm{CaO} / \mathrm{Al}_{2} \mathrm{O}_{3}=0.8\right.$; Workman and Hart, 2005). Scandium is usually considered to be a proxy of $\mathrm{Ca}$ as it partitions into the same primary phases (cpx-opx) while being inert in hydrothermal processes (cf Orberger et al., 1995; Pearson et al., 2014 and ref. therein). L'Orgerais harzburgites fall in the mantle arrays in the Sc vs. $\mathrm{Al}_{2} \mathrm{O}_{3}$ plot of Fig. 8 and their 410 very high $\mathrm{Sc} / \mathrm{CaO}$ ratios (0.04-0.08 vs. 0.0004 for the $\mathrm{DMM})$ clearly point to a secondary $\mathrm{CaO}$ loss. In contrast, Ty Lan and Pont de Barel peridotites preserved higher whole-rock $\mathrm{CaO} / \mathrm{Al}_{2} \mathrm{O}_{3}$ (0.3-0.8) and much lower $\mathrm{Sc} / \mathrm{CaO}(0.001-0.0008)$, closer to the range of DMM values. Both $\mathrm{CaO}$ and $\mathrm{Sc}$ in those amphibole-rich samples are mostly hosted in pargasite that predate $\underline{\mathrm{s}}$ serpentinization processes (Table S3 and S4). As a matter of fact, $\mathrm{CaO}$ positively correlates 415 with $\mathrm{Na}_{2} \mathrm{O}$ (not shown). The other south Armorican peridotites analysed (Butte de la Roche and Folie Siffait) display intermediate $\mathrm{CaO} / \mathrm{Al}_{2} \mathrm{O}_{3}(0.13-0.19)$ and $\mathrm{Sc} / \mathrm{CaO}(0.004-0.006)$; whether this trend is representative of serpentinization-related mobilization of $\mathrm{CaO}$, or related to the depletion in $\mathrm{CaO}$ of protoliths is unclear as no primary $\mathrm{Ca}$-rich minerals were preserved. Among trace elements, fluid mobile elements (FME; e.g., B, Li, As, Sb, Pb, U, Cs, Sr, $420 \mathrm{Ba}$, LREE) record chemical exchange between rock and fluid during serpentinization (Deschamps et al., 2013 and references therein). Our bulk-rock analyses bear evidence of strong $\mathrm{U}, \mathrm{Pb}$ and $\mathrm{Sr}$ enrichments compared to DMM or PM compositions (Fig. 10), as is usual 
for mantle-derived serpentinized peridotites compared to nominally anhydrous peridotites of similar compositions (Bodinier and Godard, 2014 and reference therein). Such anomalies are 425 undoubtedly a secondary enrichment feature because they are observed in all five peridotite outcrops studied here, regardless of other trace element systematics (Fig. 12). The positive U anomaly of bulk-rock analyses is not reproduced by in-situ analyses of Ty-Lan pargasite while the Pont-de-Barel pargasite is devoid of the $\mathrm{Sr}$ anomaly carried by bulk-rock analyses (compare Fig. 9 and Fig. 11). One may infer that both elements are mainly hosted in serpentinized olivine and pyroxenes. Hydrothermal remobilisation may also add LREE to altered peridotites and this secondary addition can be seen through binary plots involving highly inert elements of similar incompatible behaviour such as Nb or Th (Paulick et al., 2006; Deschamps et al., 2013). The plots in Fig. 13 clearly show two Butte de la Roche and several Ty Lan samples with anomalously high $\mathrm{La} / \mathrm{Nb}$ and $\mathrm{Ce} / \mathrm{Th}$ ratios compared to mantle-derived 435 peridotites, whether abyssal, ophiolitic or orogenic samples. Such ratios are perfectly reproduced by in-situ analyses of Ty Lan pargasites (Fig. 11), which suggest a primary, protolith-derived origin for the LREE enrichment in this occurrence. We do not have in-situ analysis for the Butte de la Roche samples that are totally serpentinized (L.O.I. up to 15 wt.\%). However, their $\mathrm{La}_{\mathrm{N}} / \mathrm{Ce}_{\mathrm{N}}>1$ (Fig. 9) may be evidence for a secondary origin.

Seawater is believed to carry U, Sr, LREE and Eu whereas slab-derived fluids produced during the dehydration of sediments and altered oceanic lithosphere in the subduction channel can contribute $\mathrm{Cs}, \mathrm{Sr}, \mathrm{Rb}, \mathrm{Li}$, and LREE to altered peridotites (Paulick et al., 2006; Janecky and Seifried, 1986; Niu, 2004; Deschamps et al., 2013). As shown above, our samples are devoid of Eu positive anomalies compared to serpentinized abyssal peridotites (Fig. 9) while

445 showing strong enrichments in $\mathrm{Cs}, \mathrm{Rb}$ and $\mathrm{Li}$ that are considered to concentrate in slab-derived fluids (Fig. 10; Fig. 12). The high Li, Cs and Ba contents in totally serpentinized Butte de la 
Roche samples is noteworthy, as is their $\mathrm{La}_{\mathrm{N}} / \mathrm{Ce}_{\mathrm{N}}>1$ (see above). However, a uniform, low-T origin for these enhanced concentrations of $\mathrm{Cs}, \mathrm{Rb}, \mathrm{Ba}$ and $\mathrm{Li}$ is unlikely because 1) there is no covariation with $\mathrm{U}, \mathrm{Sr}$ and $\mathrm{Pb}$ 2) in-situ analyses reveal high concentrations of $\mathrm{Cs}, \mathrm{Rb}, \mathrm{Ba}$ and

$450 \mathrm{Li}$ in Ty Lan and Pont de Barrel pargasite, reflecting the bulk-rock concentrations (Table S4 and Fig. 11). It is the pargasite modal abundance that produces the broadly positive correlations in binary plots of Fig $13 \mathrm{~A}, \mathrm{~B}, \mathrm{C}$ and $\mathrm{F}$.

\subsection{Nature and origin of the protoliths}

Serpentinization had indisputable but limited effects on the bulk-rock geochemistry of South Armorican peridotites: a widespread contamination in the FME U, Pb and/or $\mathrm{Sr}$, in addition to local contamination in LREE (Butte de la Roche), and $\mathrm{CaO}$ loss (l'Orgerais, Ty Lan depleted sample TGA343A). Except for those elements, there is no evidence of widespread geochemical deviation from precursor mantle protolith, perhaps because serpentinization was

460 of «rock-dominated type» in the Paulick et al (2006) classification scheme. Immobile elements like $\mathrm{Al}_{2} \mathrm{O}_{3}, \mathrm{TiO}_{2}$, and $\mathrm{HREE}$ can provide reliable indications on protolith compositions (Orberger et al, 1995; Bodinier, 1988; Bodinier et al 1988; Fabriès et al. 1998; Ulrich et al., 2010). Alumina correlates negatively with $\mathrm{MgO}$ contents as expected for mantle-melting residues (Frey, 1985; Jacques and Green, 1980; Bodinier, 1988) (Fig. 14A). Ytterbium (and its 465 proxy Y) positively correlates with $\mathrm{Al}_{2} \mathrm{O}_{3}$ (Fig. 14B). Except Pont-de-Barel peridotites, the south Armorican peridotites studied have bulk-rock compositions strongly depleted in major $\left(\mathrm{Al}_{2} \mathrm{O}_{3}, \mathrm{TiO}_{2}\right)$ and incompatible trace elements ( $\left.\mathrm{Sc}, \mathrm{V}, \mathrm{HREE}\right)$. Their primary mineralogy corresponds to harzburgites with undetermined but likely minor proportions of altered clinopyroxene (Fig. 6). For Pont-de-Barel samples, their whole-rock compositions (as well as 
modal compositions. The fact that no clinopyroxene was identified in thin sections may be explained by the fact that clinopyroxene alteration products are very difficult to identify under the microscope (Wicks and Whittaker, 1977; Wicks et al.,1977). However, because clinopyroxene (like pargasite) is much more resistant to serpentinization, we suggest that Pont 475 de Barel clinopyroxene was replaced by pargasite before serpentinization (see below).

Variable degrees of partial melting inside the mantle can be inferred from the large range of bulk-rock and $\mathrm{Cr}$ spinel compositions. It is well known that $\mathrm{Cr}$-spinel $\mathrm{Cr} \#$ increases in parallel with the degree of partial melting (e.g. Dick and Bullen, 1984; Ellebrandt et al., 2001). Where preserved from hydrothermal alteration, this mineral provides melting degree estimates (F) increasing from 5-10\% for Pont-de-Barel lherzolites to $15-25 \%$ for Butte de la Roche samples and 20-25\% for l'Orgerais harzburgites (Fig. 3). These values are supported by the melting curves from low-P (0.5-1.5 Gpa) experiments (Jaques and Green, 1980; Bodinier, 1988) using a DMM-like mantle composition as the source (Workman and Hart, 2005) and a Rayleigh near-fractional partial melting model (Niu 1997; Seyler et al., 2004; Barth et al., 2008; Ullrich et al., 2010, Walter, 2014). The results constrain F, the degree of mantle melting, between 7 and 10\% for Pont de Barel lherzolites, to around 20\% for Butte de la Roche and Ty Lan harzburgites (except TGA343A) and 25\% for l'Orgerais and Folie Siffait samples (Fig. 14). TGA343A is the most refractory sample from the Ty Lan occurrence $(\mathrm{Ni}=2450 \mathrm{ppm}$; Table 1). Its strong depletion in $\mathrm{Sc}$, $\mathrm{Ti}$ and $\mathrm{V}$ is consistent with complete consumption of cpx that occurs for 25\% partial melting (Herzberg, 2004; Pearson et al., 2014 and ref. therein).

The three Butte de la Roche harzburgites plot significantly off the partial melting curve in the $\mathrm{Yb}$ vs. $\mathrm{Al}_{2} \mathrm{O}_{3}$ diagram in Fig. $14 \mathrm{~B}$ and their interpretation as residual peridotites is far from being supported. Their high HREE content coupled with low Mg-number (83-87) are not typical of refractory mantle peridotites, apart from the $\mathrm{cm}$-thick finely interlayered peridotites 
495 inside pyroxenite banding described in orogenic peridotite massifs (Bodinier et al., 1988; Bodinier and Godard, 2014 and reference therein). The Butte de la Roche harzburgites plot in an area where peridotite and websterites overlap in the $\mathrm{SiO}_{2} / \mathrm{MgO}$ vs. $\mathrm{Al}_{2} \mathrm{O}_{3}$ diagram of Fig. 6B. Thus, there is possibility that the Butte de la Roche harzburgites incorporated pyroxenites or pyroxenes from former pyroxenites that were dispersed within the peridotites by crustal 500 shearing deformation. Although these rocks are now totally serpentinized, the pyroxene contamination scheme may account for the coupled enrichment in trace transition elements (Sc, Cr, V, Ti, Zn) and HREE.

9.3 Cryptic metasomatism in l'Orgerais and Folie Siffait harzburgites.

Our sampling provides compelling evidence for a great diversity of metasomatic 505 processes that partly obliterated the partial melting history or south Armorican peridotites. These processes operated under different physical conditions within each of the five outcrops studied. Hereafter, for the sake of the discussion, we will adopt a well-accepted terminology in mantle petrology (Menzies and Dupuy, 1991; Bodinier and Godard, 2014), in making distinction between cryptic (i.e. trace element enrichment without precipitation of new phases) 510 and modal metasomatism (trace element enrichments + precipitation of new minerals).

L'Orgerais and Folie Siffait harzburgites show indisputable evidence of cryptic metasomatism, such as incompatible trace element enrichments (including LILE : $\mathrm{Cs}, \mathrm{Rb}, \mathrm{Ba}$, Th, La, Ce) coupled with strong depletion in basalt-forming major elements. Their spoonshaped to U-shaped primitive-mantle normalized patterns in Fig. 10 have now been reported

515 on a worldwide basis for olivine-rich mantle rocks, whether orogenic harzburgites (e.g. Lherz, Pyrénées, France; Bodinier et al., 1988; Fabriès et al., 1998; Downes et al., 1991; Le Roux et 
al., 2007; Ronda, Van der Vall and Bodinier, 1996), ophiolitic harzburgites (e.g. New Caledonia (Ullrich et al., 2010); Cuba (Proenza et al., 2000), Seram Ambon, Indonesia, (Monnier et al., 2003)), or fore-arc peridotite xenoliths (e.g. Izu Bonin, Mariana; Parkinson 520 and Pearce, 1998). Basically, ophiolitic and fore-arc xenolithic harzburgites are widely thought to have formed from fluid-assisted second-stage melting of already depleted mantle in suprasubduction zone settings, followed by percolation of Incompatible trace element (ITE)enriched small melt fractions (Duncan and Green, 1987; Orberger et al., 1995; Barth et al., 2008; Ullrich et al., 2010). Whether partial melting and hydrous melt percolation are closely

525 linked or occured as discrete, separated events has been widely debated from unserpentinized peridotites (e.g., Bodinier and Godard, 2014). Reactive melt percolation models predict that ITE that do not enter major mantle minerals can be concentrated in evolved liquid after a certain duration of percolative reactive melt transport (Godard et al., 1995). Our limited and completely altered sampling does not allow us more speculation. However, it is worth noting 530 that l'Orgerais harzburgites display very similar PM-normalized ITE patterns as Izu-Bonin Mariana fore-arc peridotite xenoliths (Fig. 10). Arc- or back-arc geotectonic settings are well suited for such fluid percolation because of inverted geothermal gradients existing inside the mantle wedges above subducted slabs (Navon and Stolper 1987; Takazawa et al. 2003; Bodinier and Godard 2014 and references therein).

9.4 Modal metasomatism in Pont-de-Barel lherzolites and Ty Lan harzburgites.

There is little doubt that rounded pargasite porphyroclasts preserving twin growths predate serpentinization and syn-emplacement deformation of Pont de Barel lherzolites and Ty Lan harzburgites. Pargasite requires high temperature $\left(900^{\circ} \mathrm{C}\right.$, up to $1100^{\circ} \mathrm{C}$, depending on its Ti content) to crystallize in ultramafic compositions (Helz, 1982). Its Na content is also a 
540 complex function of P and T. Niida and Green (1999), Green (2015) and Fumagalli et al. (2009) collectively concluded that the richteritic substitution $\left({ }^{\mathrm{B}} \mathrm{Ca}_{-1}{ }^{\mathrm{AV}}-{ }^{\mathrm{B}} \mathrm{Na}_{1}{ }^{\mathrm{A}} \mathrm{Na}_{1}\right)$ correlates with pressure (see also Pirrar and Hermann, 2015). According to these experimental data, the Pont-de-Barel and Ty Lan pargasite crystallized within the lowest P range (1.5-2 GPa) of the pargasite stability field. Pont de Barel pargasites that are slightly enriched in $\mathrm{Ti}, \mathrm{Na}$ and $\mathrm{Si}$

545 may have crystallized at slightly higher $\mathrm{P}$ and $\mathrm{T}$ compared to Ty Lan pargasites, although this shift in $\mathrm{P}$ and $\mathrm{T}$ conditions cannot be accurately determined.

Pargasitic amphiboles were reported from a wide range of mantle peridotites encompassing margin or OCT (Ocean Continent Transition zone) peridotites (Agrinier et al. 1993), orogenic peridotites (Fabriès et al., 1991, 1998; Ionov and Hoffman, 1995; Bodinier et 550 al. 1990; Zanetti et al. 1996, Vanucci et al., 1995), transform faults (Brunelli and Seyler, 2010), as well as in ophiolites and arc-related peridotite xenoliths (McInnes et al., 2001; Grégoire et al., 2002, 2008; Coltorti et al., 2007; Ishimaru et Arai 2008 and reference therein). Pargasite in South Armorican peridotites shows HFSE systematics, especially $\mathrm{Ti} / \mathrm{Nb}$, and $\mathrm{Zr} / \mathrm{Nb}$ ratios closer to those of pargasites from arc-related xenoliths compared to pargasite in continental 555 mantle rocks (McInnes et al., 2001; Grégoire et al., 2002, 2008; Coltorti et al., 2007). Likewise, the high $\mathrm{Fe}^{3+} / \mathrm{Fe}^{3+}+\mathrm{Fe}^{2+}$ ratio (0.5-1) of Ty Lan and Pont de Barel pargasite suggests crystallization from a highly oxidized medium as expected for subducted slab-derived hydrous fluids. Beyond these compositional similarities, trace element distribution patterns and thin section microtextures provide compelling evidence for two different pargasite precipitation processes in our South Armorican peridotites.

Compared to Ty Lan pargasite, Pont-de-Barel pargasite is richer in $\mathrm{Ti}$ and poorer in $\mathrm{Cr}$, in agreement with its crystallization from a rather fertile lherzolitic protolith. As discussed in 
8.2, such a protolith should have contained clinopyroxene ( $>10$ vol. \%), which was not identified in our thin sections. Thus, Pont de Barel metasomatic pargasite could reasonably be 565 interpreted as a replacement product of clinopyroxene. Experiments (e.g. Helz, 1982) and observations in nature suggest that pargasite can be produced in the lithospheric mantle through reaction between clinopyroxene, spinel and hydrous fluids (e.g. Nickel and Green, 1984; Fabriès et al., 1991). This reaction is supported by abundant relict inclusions of Al spinel inside Pont-de- Barel pargasite. Likewise, such a reaction between hydrous fluids and

570 clinopyroxene can account for the bulk-rock CI chondrite-normalized REE patterns and the fact that pargasite is the major host of the incompatible trace element budget of Pont-de-Barel lherzolites (Fig. 11). These rocks show selective LREE enrichment coupled with nearly unfractionated MREE and HREE relative abundances similar to depleted MORB mantle (DMM) composition. It is well known that clinopyroxene is the major host for REE in

575 unmetasomatized mantle lherzolites corresponding to the DMM composition (Bodinier and Godard, 2014 and references therein). By comparison with previous work on mantle lherzolites (Bodinier et al., 1988; Downes et al., 1991, Seyler et al, 2004; Bedini and Bodinier, 1999; Pearson et al., 2014), the hypothetical precursor clinopyroxene in Pont-de-Barel lherzolites may be assumed to have provided MREE, HREE along with Ti, Zr, and Hf contents 580 as well as part of the transition element budget $(\mathrm{Sc}, \mathrm{V}$, and $\mathrm{Ti})$. By reacting out, the clinopyroxene produced pargasite that inherited its lithophile trace element budget from both the residual clinopyroxene and the LILE- and LREE-enriched metasomatic fluid. The nearly constant bulk-rock $\mathrm{Al}_{2} \mathrm{O}_{3}$ contents suggest that this metasomatic reaction was isochemical for major elements, despite large variation in the elements preferentially partitioned into pargasite 585 (e.g. Ti, Sc, Ba, Rb, Li, Sr; Table S4 and Figs 8; 12). If pargasite had been a primary 
precipitate, its amount (up to 10 vol. \% according to visual modal estimates on thin section) might have resulted in drastic changes in bulk-rock $\mathrm{Al}_{2} \mathrm{O}_{3}$ and $\mathrm{CaO}$ contents that are not observed in our sampling.

Unlike Pont de Barel pargasite, there are neither thin section data nor geochemical 590 evidence suggesting a direct replacement of clinopyroxene by pargasite in Ty Lan harzburgites. Ty Lan pargasite may occur as clusters or aggregates of several crystals networking, suggesting that it was a primary precipitate from intergranular melt or fluids. Extensive melt percolation inside a refractory harzburgitic protolith may account for the Cr-rich composition of Ty-Lan pargasite and the low Mg number (90) of Ty Lan olivine compared with the inferred

595 modal composition of host rock (c.f. Arai 1994; Orberger et al., 1995; Beard and Johnson, 2004). Finally, some elements entering pargasite eompesition (e.g. Sc, V, Sr) display positive correlations with $\mathrm{Al}_{2} \mathrm{O}_{3}$ (Fig. 8) that may be interpreted as refertilization trends. For instance the bulk-rock major element composition of TGA346AB, the most fertile and pargasite-rich Ty Lan harzburgite can be reproduced by adding $10 \%$ pargasite to the most depleted harzburgite TGA343A.

Regarding the composition of this putative silicate melt that precipitated pargasite in Ty lan harzburgites, the very high LREE and MREE contents of Ty Lan pargasite have been documented only in highly metasomatised amphibole-rich orogenic peridotites that have reacted with alkali basalts (e.g. Caussou, Fabriès et al., 1989) or in Ti-rich pargasite collected 605 in the vicinity of high-pressure cumulates from alkali basalt (Bodinier et al., 1990; Downes et al., 1991; Zanetti et al., 1996; Liu et al., 2010). An alkali melt composition is supported by the overall negatively trending CI-chondrite normalized REE patterns of Ty Lan harzburgites and its pargasite. However the strong HFSE depletion of Ty Lan samples is in disagreement with 
orogenic Ti-rich amphibole. This observation points to the origin of this putative metasomatic

610 alkali melt from supra-subduction mantle wedge.

\section{Conclusions.}

Our new data identify South Armorican peridotites as mantle-derived peridotites having

615 experienced moderate alteration of their fluid mobile element inventory by serpentinization. Immobile major element concentrations and preserved primary minerals (e.g., Cr-spinel) point to very variable degrees of melt depletion. Pont de Barel lherzolites represent the most fertile end members. All four other occurrences are identified as harzburgites having experienced up to $25 \%$ partial melting. Such rocks at Ty Lan are consistent with geological mapping of an 620 ophiolitic complex.

South Armorican peridotites bear evidence of a complex metasomatism history postdating partial melting. The most refractory l'Orgerais and Folie Siffait harzburgites show evidence of cryptic metasomatism, perhaps associated with secondary melting. Hightemperature pargasite precipitation indicates hydrous modal metasomatism in both Pont de

625 Barel lherzolites and Audierne harzburgites. This pargasite precipitated in Pont de Barel lherzolites by reaction of residual clinopyroxene with incompatible trace element-enriched small-volume fluids. It was a primary precipitate from alkali-rich hydrous melts that pervasively refertilized the Ty Lan harzburgites.

South Armorican peridotites are not easy to constrain in terms of geotectonic

630 provenance. A large degree of freedom remains for Pont-de-Barel lherzolites, from continental mantle to ocean-continent transition or back-arc settings (Menzies and Dupuy, 1991; Bodinier 
and Godard, 2014 and reference therein.). Bulk-rock major and trace element compositions of the other peridotite occurrences studied suggest an origin from a paleo-oceanic lithosphere, from abyssal to mantle wedges or fore-arc settings. Unlike abyssal peridotites, however, South

635 Armorican harzburgites are devoid of positive Eu anomalies.

Mantle wedge serpentinites and arc peridotites show on average low bulk $\mathrm{TiO}_{2}$ (and depleted HFSE contents), Fe-rich Cr-spinel, and large LILE enrichments (Arai, S., 1994; Arai et al., 2003; Grégoire et al., 2007; Bédard et al., 2009; Deschamps et al., 2013; Bodinier and Godard, 2014 and references therein), all three features that are reproduced by our South Armorican

640 harzburgites. Melting degrees exceeding $20 \%$ are usually ascribed to supra-subduction settings, because slab-derived hydrous fluids lower melting temperatures (Duncan and Green, 1987; Orberger et al., 1995). The coupled occurrence of harzburgites and chromite as recorded by Ty Lan samples were also reported from supra-subduction zone ophiolites. Regardless of their ultimate origin, both lherzolites and harzburgites may display sign of interaction with

645 oxidized slab-derived melt/fluids, as suggested by metasomatic pargasite displaying Li-, Cs-, Rb-, Ba- enriched and HFSE-depleted composition.

\section{Acknowledgements.}

This work was made possible thanks to a «Pays de la Loire-BRGM-Institut Carnot» joint grant 650 to Geoffrey Aertgeerts. Financial funding for analytical work was provided by LPGNantesCNRS. Jessica Langlade is thanked for her help during electron microprobe analyses, Laurent Lenta for the thin sections and Roger H. Hewins for having corrected the English. The authors are grateful to an anonymous reviewer and Elisabeta Rampone who greatly improved this 
manuscript.

655

\section{References}

Aertgeerts, G., Lorand, J.-P., Monnier, C., La C., Lahondère, D., 2015. New petrological and geochemical constraint on amphibolites and serpentinised peridotites from the variscan Champtoceaux complex, south armorican Massif, France. The variscan belt: correlation and plate dynamics. Special meeting of the French and Spanish Geological societies. Géologie de la France

660

Agrinier, P., Mével, C., Bosch, D., Javoy, M., 1993. Metasomatic hydrous fluids in amphibole peridotites from Zabargad Island (Red Sea). Earth and Planetary Science Letters 120, 187205.

Arai, S., 1994. Characterization of spinel peridotites by olivine-spinel compositional 665 relationships: Review and interpretation. Chemical Geology 113, 191-204.

Arai, S., Ishimaru, S., Okrugin, V.M., 2003. Metasomatized harzburgite xenoliths from Avacha volcano as fragments of mantle wedge of the Kamchatka arc: Implication for the metasomatic agent. The Island Arc 12, 233246.

Austrheim, H., Prestvik, T., 2008. Rodingitization and hydration of the oceanic lithosphere as 670 developed in the Leka ophiolite, north-central Norway. Lithos 104, 177-198.

Bach, M., Klein, F., 2008. The petrology of seafloor rodingites: Insights from geochemical reaction path modeling. Lithos 112, 103-117.

Ballèvre, M., Bosse, V., Ducassou, C., Pitra, P., 2009. Palaeozoic history of the Armorican Massif: Models for the tectonic evolution of the suture zones. Comptes Rendus Geoscience $675341,174201$. 
Ballèvre, M., Bosse, V., Dabard, M., Ducassou, C., Fourcade, S., Paquette, J., Peucat, J., Pitra, P., 2013. Histoire géologique du Massif armoricain : actualité de la recherche, 596.

Ballèvre, M., Capdevila, R., Guerrot, C., Peucat, J.-J., 2002. Discovery of an alkaline orthogneiss in the eclogite-bearing Cellier Unit (Champtoceaux Complex, Armorican 680 Massif): a new witness of the Ordovician rifting. Comptes Rendus Geoscience, 334, 303311.

Ballèvre, M., Martinez Catalan, J.R., Lopez-Carmona, A., Pitra, P., Abati, J., Fernandez, R.D., Ducassou, C., Arenas, R., Bosse, V., Castineiras, P., (2014) Correlation of the nappe stack in the Ibero-Armorican arc across the Bay of Biscay: a joint French-Spanish project. 685 Geological Society, London, Special Publications, 77-113.

Barth, M.G., Mason, P.R.D., Davies, G.R., Drury, M.R., 2008. The Othris Ophiolite, Greece: a snapshot of subduction initiation at a mid-ocean ridge. Lithos 100 (1-4), 234-254.

Beard, B.L., Johnson, C.M., 2004. Inter-mineral Fe isotopic variations in mantle-derived rocks and implications for the Fe geochemical cycle. Geochimica et Cosmochimica Acta 68: $4727-4743$.

Béchennec, F., 2007. Carte géologique harmonisée du département de Loire-Atlantique BRGM/RP-55703-FR.

Béchennec, F., Hallégouët, B., Thiéblemont, D., Guerrot, C., Cocherie, A., Carn, A., 1999. 695 Notice explicative, Carte géol. France (1/50 000), feuille de Quimper (346). Orléans BRGM. Géological map by Béchennec et al. (1999), 160 pp. 
Bédard, É., Hébert, R., Guilmette, C., Lesage, G., Wang, C.S., et Dostal, J. 2009. Petrology and geochemistry of the Saga and Sangsang ophiolitic massifs, Yarlung Zangbo Suture Zone, Southern Tibet: Evidence for an arc-back-arc origin. Lithos 113, 48-67.

700 Bernard-Griffiths, J., Cornichet, J., 1985. Origin of eclogites from South Brittany, France: A Sm-Nd isotopic and REE study. Chemical Geology 52, 185-201.

Bodinier, J.-L., 1988. Geochemistry and petrogenesis of the Lanzo peridotite body, Western Alps. Tectonophysics 149, 67-88.

705

Bodinier, J.-L., Dupuy, C., Dostal, C., 1988. Geochemistry and petrogenesis of Eastern Pyrenean peridotites. Geochimica et Cosmochimica Acta 52, 2893-2907.

Bodinier, J.L., and Godard, M. (2014) Orogenic, Ophiolitic, and Abyssal Peridotites, 3e éd., 710 vol 3-4 pp. 103-167. Treatise on Geochemistry: Second Edition Vol. 3. Elsevier Ltd.

Bodinier, J.L., Vasseur, G., Vernières, J., Dupuy, C., Fabries, J., 1990. Mechanisms of Mantle Metasomatism: Geochemical Evidence from the Lherz Peridotite. Journal of Petrology 31, 597628.

Bosse, V., Feraud, G., Ruffet, G., Balle, M., 2000. Late Devonian subduction and early715 orogenic exhumation of eclogite-facies rocks from the Champtoceaux Complex (Variscan belt, France ), 325, 297-325.

Brunelli, D., Seyler, M., 2010. Asthenospheric percolation of alkaline melts beneath the St. Paul region (Central Atlantic Ocean). Earth and Planetary Science Letters 289: 393-405. 
720 Cagnard, F., 2008. Carte géologique harmonisée du département du Finistère notice géologique - BRGM/RP- 56273 - FR.

Canil, D., 2002. Vanadium in peridotites, mantle redox and tectonic environments: Archean to present. Earth and Planetary Science Letters 195, 75-90.

725

Chazot, G, Menzies, M.A., Harte, B., 1996. Determination of partition coefficients between apatite, clinopyroxene, amphibole and melt in natural spinel lherzolites from Yemen: Implications for wet melting of the lithospheric mantle. Geochimica et Cosmochimica Acta $60,423-437$.

730

Cooperdock, E.G., Raia, N.H., Barnes, J.D., Stockli, D.F., Schwarzenbach, E.M. (2018) Tectonic origin of serpentinites on Syros, Greece: Geochemical signatures of abyssal origin preserved in a HP/LT subduction complex. Lithos 296-299, 352-364

735

Coleman, R. G., Keith, T. E., 1971. A chemical study of serpentinization-Burro Mountain. California. Journal of Petrology 12, 311-329.

Coltorti, M., Bonadiman, C., Faccini, B., Grégoire, M., O'Reilly, S.Y., Powell, W., 2007. 740 Amphibole from suprasubduction and intraplate lithospheric mantle. Lithos 99, 68-84.

Deschamps, F., Godard, M., Guillot, S., Hattori, K., 2013. Geochemistry of subduction zone serpentinites: A review. Lithos 178, 96127. 
Dick, H.J.B., Bullen, T., 1984. Chromian spinel as a petrogenetic indicator in abyssal and alpine-type peridotites and spatially associated lavas. Contributions to Mineralogy and $745 \quad$ Petrology 86, 54-76.

Downes H, Bodinier J-L, Thirlwall MF, Lorand J-P, and Fabries J (1991) REE and Sr-Nd isotopic geochemistry of the Eastern Pyrenean peridotite massifs: Sub-continental lithospheric mantle modified by continental magmatism. Orogenic Lherzolites and Mantle 750 Processes. Journal of Petrology Special Volume, 97-115.

Duncan, R.A., Green, D.H., 1987. The genesis of refractory melts in the formation of oceanic crust. Contribution to Mineralogy and Petrology 96, 326-342.

Fabriès, J., Bodinier, J.-L., Dupuy, C., Lorand, J.-P., and Benkerrou, C. (1989) Evidence for modal metasomatism in the orogenic spinel lherzolite body from Caussou (Northeastern 755 Pyrénées, France). Journal of Petrology 30, 199-228.

Fabriès, J., Lorand, J.-P., Bodinier, J.-L., 1998. Petrogenetic evolution of orogenic lherzolite massifs. Tectonophysics 292, 145-167.

Fabriès, J., Lorand, J.-P., Bodinier, J.-L., and Dupuy, C. (1991) Evolution of the upper mantle beneath the Pyrenees: Evidence from orogenic spinel lherzolite massifs. Orogenic 760 Lherzolites and Mantle Processes. Journal of Petrology Special Volume 55-76.

Faure, M., Mézème, E.B., Cocherie, A., Rossi, P., Chemenda, A., Boutelier, D. (2008) Devonian geodynamic evolution the Variscan Belt, insights from the French Massif Central and Massif Armoricain. Tectonics 27, 119. 
Faure, M., Lardeaux, J.-M., Ledru, P. (2009) A review of the pre-Permian geology of the Variscan French Massif Central. Comptes Rendus Geoscience 341, 202213.

Frey, F.A., Suen, C.J., and Stockman, H.W. (1985) The Ronda high temperature peridotite: 770 Geochemistry and petrogenesis. Geochimica et Cosmochimica Acta 49, 2469-2491.

Frost, B., R. and Beard, J., S., 2007. On silica activity and serpentinization. Journal of Petrology, 48, 1351-1368.

Godard, M., Bodinier, J.-L., Vasseur, G., 1995. Effects of mineralogical reactions on trace 775 element redistributions in mantle rocks during percolation processes: a chromatographic approach. Earth Planetary Science Letters 133, 449-461.

Green, D.H., 2015. Experimental petrology of peridotites, including effects of water and carbon on melting in the Earth's upper mantle. Physics and Chemistry of Minerals 42, 780 95122.

Grégoire M., Bell, D.R., Le Roex, A.P., 2002. Trace element geochemistry of phlogopite-rich mafic mantle xenoliths: theirclassification and their relationship to phlogopite-bearing peridotites and kimberlites revisited. Contributions to Mineralogy and Petrology 142, 603625. 
Grégoire, M., Jego, S., Maury, R.C., Polvé, M., Payot, B., Tamayo R.A.Jr., Yumul, G.P. Jr., 2008. Metasomatic interactions between slab-derived melts and depleted mantle: Insights from xenoliths within Monglo adakite (Luzon arc, Philippines). Lithos 103, 415-430.

790 Harvey, J., Savov, I.P., Agostini, S., Cliff, R.A., Walshaw, R., 2014. Si-metasomatism in serpentinized peridotite : The effects of talc-alteration on strontium and boron isotopes in abyssal serpentinites from Hole 1268a, ODP Leg 209. Geochimica et Cosmochimica Acta 126,3048 .

795 Hawthorne, F.C., Oberti, R., Harlow, G.E., Maresch, W. V., Martin, R.F., Schumacher, J.C., Welch, M.D., 2012. Ima report: Nomenclature of the amphibole supergroup. American Mineralogist 97, 20312048.

Hellebrand, E., Snow, J.E., Dick, H.J.B., Hofmann, A.W., 2001. Coupled major and trace elements as indicators of the extent of melting in mid-ocean-ridge peridotites. Nature 410, $800 \quad 677-681$.

Helz, R.T., 1982. Experimental studies on amphibole stabilities. Review in Mineralogy 12, 279-346.

Herzberg, C.T. , 2004. Geodynamic Information in Peridotite Petrology. Journal of Petrology $805 \quad 45,1-24$

Ionov, D. A., Hofmann, A. W., 1995. Nb-Ta-rich mantle amphiboles and micas: implications for subduction-related metasomatic trace element fractionations. Earth Planetary Science 
Letters $131,341-356$.

810 Ishimaru, S., Arai, S., 2008. Calcic amphiboles in peridotite xenoliths from Avacha volcano, Kamchatka, and their implications for metasomatic conditions in the mantle wedge. Geological Society, London, Special Publications 293, 3555.

Jaques, A.L., Green, D.H.,1980. Anhydrous melting of peridotite at $0-15 \mathrm{~Kb}$ pressure and the genesis of tholeiitic basalts. Contributions to Mineralogy and Petrology 73, 287-310.

815

Janecky, D.R., Seyfried Jr., W.E., 1986. Hydrothermal serpentinization of peridotite. Geochimica et Cosmochimica Acta 48, 1351-1368.

Jochum K.P., Weis U., Stoll B., Kuzmin D., Yang Q., Raczek I., Jacob D.E., Stracke A., 820 Birbaum K., Frick D.A., Günther D., Enzweiler J., 2001. Determination of Reference Values for NIST 610-617 Glasses Following ISO Guidelines. Geostandard and Geoanalytical Research 35(4), 397-429.

Le Roux, V., Bodinier, J.-L., Tommasi, A., et al., 2007. The Lherz spinel lherzolite: 825 Refertilized rather than pristine mantle. Earth and Planetary Science Letters 259, 599-612.

Liu, C.Z., Wu, F.Y., Wilde, S. A., Yu, L.J., Li, J.L., 2010. Anorthitic plagioclase and pargasitic amphibole in mantle peridotites from the Yungbwa ophiolite (southwestern Tibetan Plateau) formed by hydrous melt metasomatism. Lithos 114, 413422. 
830 Locock, A.J., 2014. An Excel spreadsheet to classify chemical analyses of amphiboles following the IMA 2012 recommendations. Computers and Geosciences 62, 111.

Lorand, J.-P., Ceuleneer, G., 1989. Silicate and base-metal sulfide inclusions in chromites from the Maqsad area (Oman ophiolite) : a model for entrapment. Lithos 22, 173-191.

Marchand, J., Perrin, J., Weeksteen, G., Forestier, F.H., Lasnier B., 1969. Notice explicative, 835 Carte géol. France (1/50 000), feuille de Vallet (482). Orléans BRGM. Geological map by Marchand et al. (1969).

Marchand, J., Sellier, D., Alix, Y., Etienne, H., Lulzac, Y., 1989. Notice explicative, Carte géol. France (1/50 000), feuille de Savenay (450). Orléans BRGM. Geological map by Marchand et al. (1989).

840 McDonough, W. F., Sun, S. S., 1995. The composition of the earth. Chemical Geology 120, $223-253$.

Mcinnes, B.I.A., Grégoire, M., Binns, R.A., Herzig, P.M., Hannington, M.D., 2001. Hydrous metasomatism of oceanic sub-arc mantle, Lihir, Papua New Guinea: petrology and geochemistry of fluid-metasomatised mantle wedge xenoliths. Earth and Planetary Science 845 Letters 188, 169-183.

McPherson, E., Thirlwall, M.F., Parkinson, I.J., Menzies, M.A., Bodinier, J.-L., Woodland, A., and Bussod, G., 1996. Geochemistry of metasomatism adjacent to amphibole-bearing veins in the Lherz peridotite massif. Chemical Geology134, 135157.

Menzies, M.A., Dupuy, C., 1991. Orogenic massifs: Protolith, process and provenance. 850 Orogenic Lherzolites and Mantle Processes. Journal of Petrology Special Volume, 1-16. 
Mercier, J.-C.C., Nicolas, A., 1975. Textures and fabrics of upper-mantle peridotites as illustrated by xenoliths from basalts. Journal of Petrology 16, 454-487.

Mével, C., 2003. Serpentinization of abyssal peridotites at mid-ocean ridges. Comptes Rendus 855 Geoscience 335, 825852.

Monnier, C., Girardeau, J., Permana, H., Rehault, J.-P., Bellon, H., Cotten, J., 2003. Dynamics and age of formation of the Seram-Ambon ophiolites (Central Indonesia). Bulletin de la Sociéte Géologique de France 174, 529-543.

860 Navon, O., Stolper, E., 1987. Geochemical consequences of melt percolation: the upper mantle as chromatographic column. The Journal of Geology 95, 285307.

Nickel, K. G., Green, D. H., 1984 The nature of the upper-most mantle beneath Victoria, Australia as deduced from ultramafic xenoliths. Developments in Petrology (11B) $865 \quad$ Kimberlites, Vol. 2, pp. 161-178.

Niida, K., Green, D.H., 1999. Stability and chemical composition of pargasitic amphibole in MORB pyrolite under upper mantle conditions. Contributions to Mineralogy and Petrology $135,1840$.

Niu, Y., 1997. Mantle melting and melt extraction processes beneath ocean ridges: Evidence 870 from abyssal peridotites. Journal of Petrology 38, 1047-1074. 
Niu, Y., 2004. Bulk-rock major and trace element compositions of abyssal peridotites: implications for mantle melting, melt extraction and post-melting processes beneath midocean ridges. Journal of Petrology 45, 2423-2458.

875

Orberger, B., Lorand J.-P., Girardeau, J., Mercier, J.C.C., Pitragool S., 1995. Petrogenesis of ultramafic rocks and associated chromitites in the Nan-Uttaradit ophiolite, Northern Thailand, Lithos 35, 153-182.

880 Parkinson, I.J., Pearce, J.A., 1998. Peridotites from the Izu-Bonin- Mariana Forearc (ODP Leg 125): evidence for mantle melting and melt-mantle interaction in a supra-subduction zone setting. Journal of Petrology 39, 1577-1618.

Paquette, J.-L., Peucat, J.-J., Bernard-Griffiths, J., Marchand, J., 1985. Evidence for old 885 Precambrian relics shown by U-Pd zircon dating of eclogites and associated rocks in the Hercynian belt of South Brittany, France. Chemical Geology 52, 203216.

Paulick, H., Bach, W., Godard, M., Hoog, C.-J., Suhr, G, Harvey, J., 2006. Geochemistry of abyssal peridotites (Mid-Atlantic Ridge, 1520’N, ODP Leg 209): Implications for fluid/rock 890 interaction in slow spreading environments. Chemical Geology 234, 179-210.

Pearson, D.G., Canil, D. Shirey, S.B., 2014. Mantle Samples Included in Volcanic Rocks: Xenoliths and Diamonds Holland HD and Turekian KK (eds.) Treatise on Geochemistry. 2nd edition. In: Carlson RW (ed.) Oxford: Elsevier-Pergamon. The Mantle and Core, vol. 35, pp. 170-229. 
895 Peters, D., Pettke, T. 2017. Evaluation of Major to Ultra Trace Element Bulk Rock Chemical Analysis of Nanoparticulate Pressed Powder Pellets by LA-ICP-MS. Geostandards and Geoanalytical Research, 41, 5-28.

Pitra, P., Ballèvre, M., Ruffet, G., 2010. Inverted metamorphic field gradient towards a 900 Variscan suture zone (Champtoceaux Complex, Armorican Massif, France). Journal of Metamorphic Geology 28, 183208.

Plaine, J., Peucat, J.-J., Morzadec-Kerfourn, M.-T., Pinot, J.-P. 1981. Notice explicative, Carte géol. France (1/50 000), feuille de Pont-Croix (345). Orléans BRGM. Geological map by Plaine et al. (1981), 48.

905

Proenza, J., Gervilla, F., Melgarejo, J.-C., Bodinier, J.-L., 1999. Al-rich and Cr-rich chromitites from the Mayari-Baracoa ophiolitic belt (Eastern Cuba) as the consequence of interaction between volatile-rich melts and peridotites in suprasubduction mantle. Economic Geology 94, 547-566.

910

Seyler, M., Lorand, J.-P., Toplis, M.J., Godard, G., 2004. Asthenospheric metasomatism beneath the mid-ocean ridge; evidence from depleted abyssal peridotites. Geology 32, 301304.

915 Snow, J. E., Dick, H. J. B., 1995. Pervasive magnesium loss by marine weathering of peridotite. Geochimica Cosmochimica Acta 59, 4219-4235.

Takazawa, E., Okayasu, T., Satoh, K., 2003. Geochemistry and origin of the basal lherzolites 
from the northern Oman ophiolite (northern Fizh block). Geochemistry, Geophysics, 920 Geosystems, 4.2000GC000080.

Ulrich, M., Picard, C., Guillot, S., Chauvel, C., Cluzel, D., Meffre, S., 2010. Lithos Multiple melting stages and refertilization as indicators for ridge to subduction formation : The New Caledonia ophiolite. Lithos 115, 223236.

925 Walter, M.J. , 2014. Melt Extraction and Compositional Variability in Mantle Lithosphere Holland HD and Turekian KK (eds.) Treatise on Geochemistry. 2nd edition. In: Carlson RW (ed.) The Mantle and Core, vol. 2, Oxford: Elsevier-Pergamon., 393-415.

Wicks, F.J., Whittaker, E.J.W., 1977. Serpentinite texture and serpentinization. Canadian 930 Mineralogist 15, 459-488.

Wicks, F.J., Whittaker, E.J.W., Zussman, J., 1977. Model for serpentine textures after olivine. Canadian Mineralogist 15, 446-458.

Workman, R.K., Hart, S.R., 2005. Major and trace element composition of the depleted 935 MORB mantle (DMM). Earth Planetary Science Letters 231, 53-72.

Zanetti, A., Vannucci, R., Bottazzi, P., Oberti, R., Ottolini, L., 1996. Infiltration metasomatism at Lherz as monitored by systematic ion-microprobe investigations close to a hornblendite vein. Chemical Geology 134, 113-133.

\section{Figure captions}

940 Figure 1 Location and schematic geological maps of Champtoceaux (A) and Audierne (B) 
nappe stacking complexes (adaptated after Ballèvre et al., 2009, 2014 and references therein).

Figure 2 Microphotographs of thin sections of South Armorican peridotites. A : amphibole (pargasite)-olivine cluster in Ty Lan mesh-textured partly serpentinized harzburgite, crossed polariser transmitted light; B : pargasite porphyroclasts in Pont-de-Barel peridotites, crossed

945 polariser transmitted light; C : pargasite porphyroclasts in partly serpentinized Pont de Barel, crossed polariser transmitted light; $\mathrm{D}$ : green-brown $\mathrm{Cr}$-spinel associated with pargasite in Pont-de-Barel peridotites, plane polariser transmitted light; E :Cr-spinel isolated in l'Orgerais mylonitized harzburgite, plane polariser transmitted light; F : dark red anhedral spinel in l'Orgerais harzburgite; plane polariser transmitted light. G: olivine relics inside lizardite 950 networks in Folies Siffait harzburgite, crossed polariser transmitted light; $\mathrm{H}$ : highly deformed opx bastite in Folie Siffait harzburgite, plane polariser transmitted light; Amp : amphibole; Ol : olivine; Spl : spinel; Srp : serpentine; Mesh Lz : mesh lizardite; Lz : lizardite; Atg : antigorite; Mag : magnetite.

Figure $3 \mathrm{Cr} \#$ vs. Mg\# binary plot for Cr-spinel. Partial melting degrees (in percent) are from 955 the Hellebrandt et al. (2001) calibration. Compositional fields for abyssal and fore-arc peridotites are from Bédard et al. (2009).

Figure 4 Pargasite compositions in a AlIV vs. $\mathrm{Na}+\mathrm{K}$ diagram. Ed : edenite ; $\mathrm{Hb}$ : hornblende ; Pa : pargasite; Ts : Tschermakite. Amphibole compositions were treated according to the IMA (International Mineralogical Association) recommendations (Hawthorne et al. 2012) and their

960 structural formulae were calculated with the Excel spreadsheet of Locock (2014). Shaded field: compositional range of chromitite-hosted pargasite inclusions (Lorand and Ceuleneer, 1989). 
Figure 5 Ti vs. $\mathrm{Cr}$ and Ti vs. K diagram for pargasite (at.\%). Compositional field of continental peridotites from Fabriès et al. (1991).

965 Figure 6 A : Plot of South Armorican peridotite bulk-rock analyses (diamonds) in the $\mathrm{MgO} / \mathrm{SiO}_{2}$ vs. $\mathrm{Al}_{2} \mathrm{O}_{3}$ diagram of Bodinier and Godard (2014). B Plot of South Armorican peridotite bulk-rock analyses in the $\mathrm{MgO} / \mathrm{SiO}_{2}$ vs. $\mathrm{Al}_{2} \mathrm{O}_{3} / \mathrm{SiO}_{2}$ diagram of Deschamp et al. (2013). Depleted Mantle after Workman and Hart (2005); Primitive mantle after McDonough and Sun (1995). Terrestrial array after Bodinier and Godard (2014). Compositional fields for abyssal serpentinites, mantle wedge 970 serpentinites and subduction zone serpentinites after Deschamps et al. (2013).

Figure $7 \mathrm{FeO}$ vs. $\mathrm{MgO}$ and $\mathrm{CaO}$ vs. $\mathrm{MgO}$ plots for bulk-rock analyses of south Armorican peridotites (anhydrous basis). Literature data: same references as in Fig. 6. Fig. 7A is contoured with iso Mg number lines (after Deschamp et al., 2013). Depleted Mantle after Workman and Hart (2005).

975 Figure 8 Binary diagrams of transition elements vs. $\mathrm{Al}_{2} \mathrm{O}_{3}$. Compositional fields for mantle peridotites after Bodinier and Godard (2014); Stars = Depleted mantle compositions (McDonough and Sun, 1995; Workman and Hart, 2005).

Figure 9 Chondrite-normalized bulk-rock Rare Earth Element concentrations. Chondritic values after McDonough and Sun (1995). Compositional fields for serpentinites after 980 Deschamps et al. (2013). Those fields labelled "melt/rock interactions" correspond to samples that have been metasomatized within the upper mantle.

Figure 10 Extended primitive mantle-normalized bulk-rock concentrations of incompatible trace elements (ITE = Large Ion Lithophile Elements and Rare Earth Elements). Primitive mantle values after Mc Donough and Sun (1995). Compositional fields for serpentinites after 
985 Deschamps et al. (2013). Those field labelled "melt/rock interactions" correspond to samples that have been metasomatized within the upper mantle. Compositions of ophiolitic, fastspreading ridge harzburgites and arc-related harzburgites from Bodinier and Godard (2014).

Figure 11 (A) chondrite-normalized Rare Earth Element concentrations of pargasite; (B) Primitive Mantle-normalized incompatible trace element (ITE) concentrations of pargasite 990 Normalizing values from Mc Donough and Sun (1995).

Figure 12 Binary plots of Large Ion Lithophile trace elements vs $\mathrm{Al}_{2} \mathrm{O}_{3}$. DMM composition after Workman and Hart (2005).

Figure 13 Plots of Incompatible Trace Elements in $\mathrm{Nb}$ vs. La and Th vs. Ce binary diagrams (bulk-rock analyses). Arrows relating to fluid-rock and melt-rock interactions are from Paulick 995 et al. (2006). Compositional field for abyssal peridotites from Paulick et al. (2006), Deschamp et al. (2013). Orogenic and ophiolitic peridotites from Bodinier and Godard (2014).

Figure 14 Estimate of partial melting degrees from low-P experiments (Jaques and Green, 1980) or melting models (Bodinier, 1988; Herzberg, 2004); DMM mantle source from Workman and Hart (2005). The compositional fields of fore-arc peridotites are from Ullrich et 1000 al. (2010) and Bodinier and Godard (2014) for orogenic, ophiolitic and abyssal peridotites. 



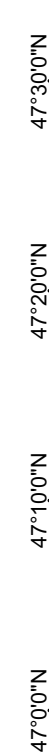
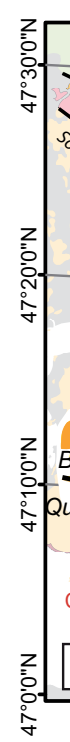

$2^{\circ} 0^{\prime} 0^{\prime \prime} \mathrm{W}$

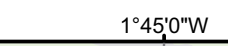

$1^{\circ} 30^{\prime} 0^{\prime \prime} \mathrm{W}$

1¹5'0"W Sillon Houiller de la Basse Loire Unit, Coal-bearing hasin
(Pennsylvanian) Ancenis Unit pull-apart

micaschiste South-Armorican
variscan Dornain

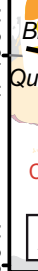

cea
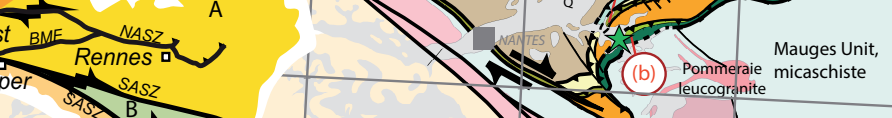

Nan
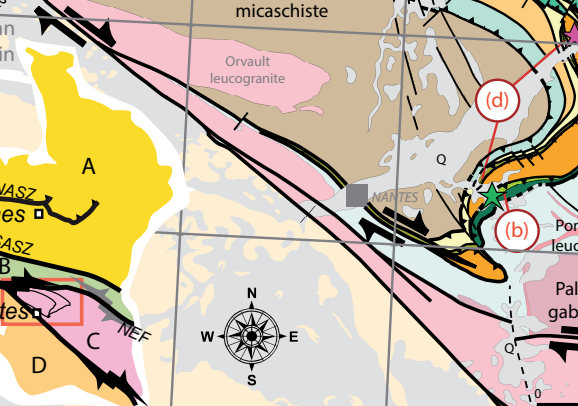

$2^{\circ} 0^{\prime} 0^{\prime \prime} \mathrm{W}$
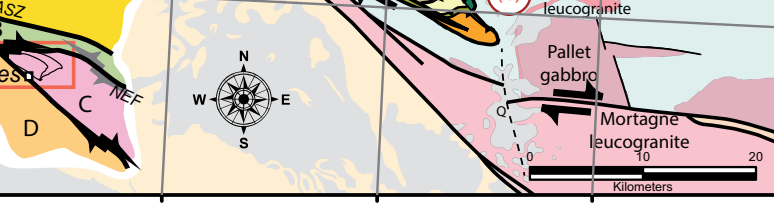

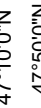

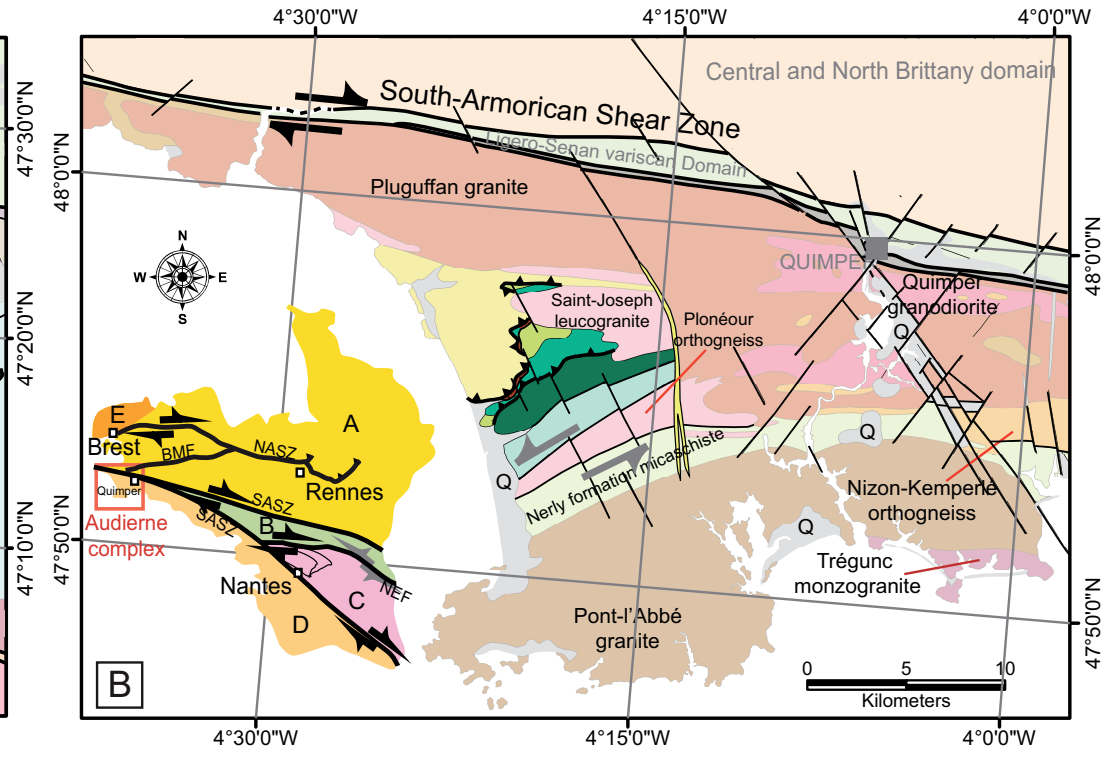

$1^{\circ} 30^{\prime} 0 " \mathrm{~W} \quad 1^{\circ} 15^{\prime} 0^{\prime \prime} \mathrm{W}$

Armorican Massif Domains

Pont de Barel Formation, amphibolites

Drain Formation,

metagabbro and amphibolite (upper Devonian)

Le Hâvre Formation,

micaschiste et amphibolite

Champtoceaux Formation, orthogneiss

Folies Siffait Formation, amphibolite $\square$ micaschiste $]$ Saint-Mars-du-Désert orthogneiss Formation

Cellier Formation micaschiste et leptynite

Peridotite and

serpentinite

(a) Pont de Barel

Penhors formation, micaschiste

Languidou-Penhors orthogneiss

일

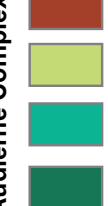

Ty-Lan serpentinites and peridotite

Peumerit formation, amphibolite and metagabbro

Tréogat formation, amphibolite, prasinite and ovardite

Trunvel formation, micaschiste

Dextral sens of shear of the SASZ

(Mississipian to Pennsylvanian)

1 Senestral sens of shear
A Central and North Brittany domain

A (Armorica microplate)

B Ligéro-sénan variscan domain

C Nantais domain

D D South armorican variscan domain

E Léon variscan domain

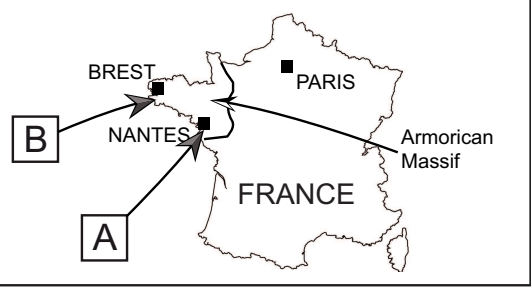

Fig. 1 


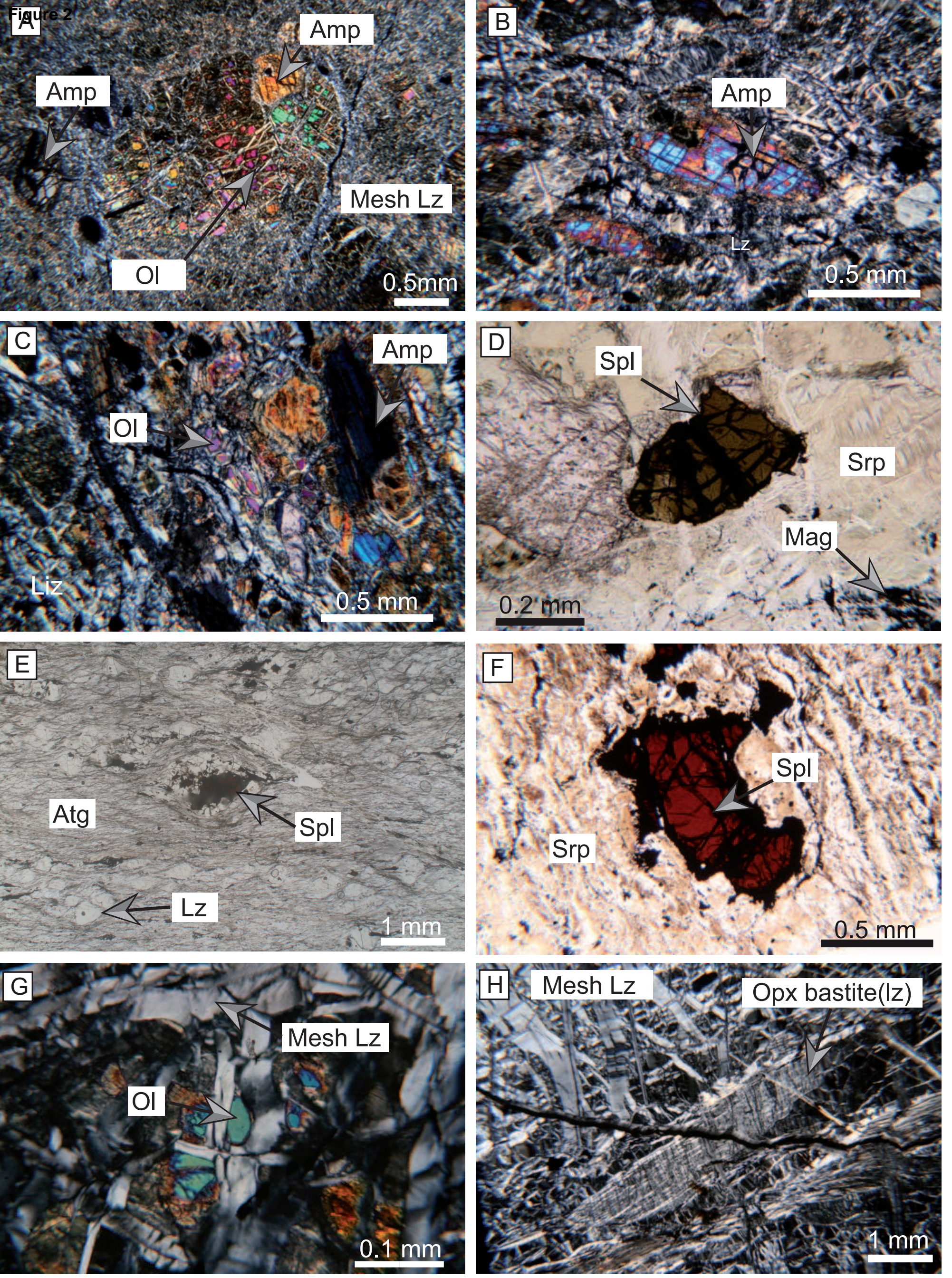




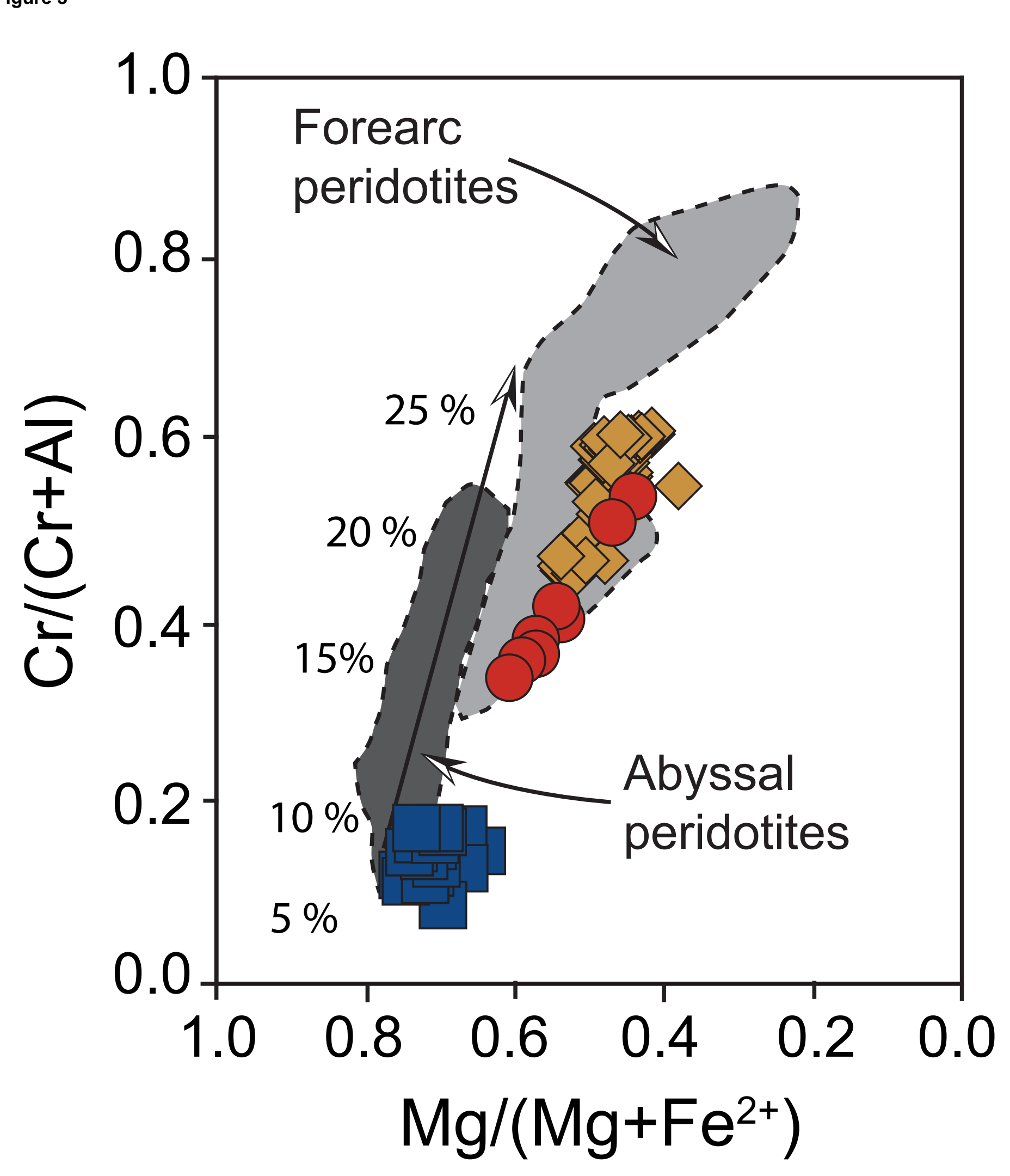

Forearc

peridotites

\section{O}

Pont de Barel

Butte de la roche

$\checkmark$ L'Orgerais

Fig. 3

Abyssal
peridotites

$0.2 \quad 0.0$

\section{$\mathrm{Mg} /\left(\mathrm{Mg}+\mathrm{Fe}^{2+}\right)$}


Figure 4

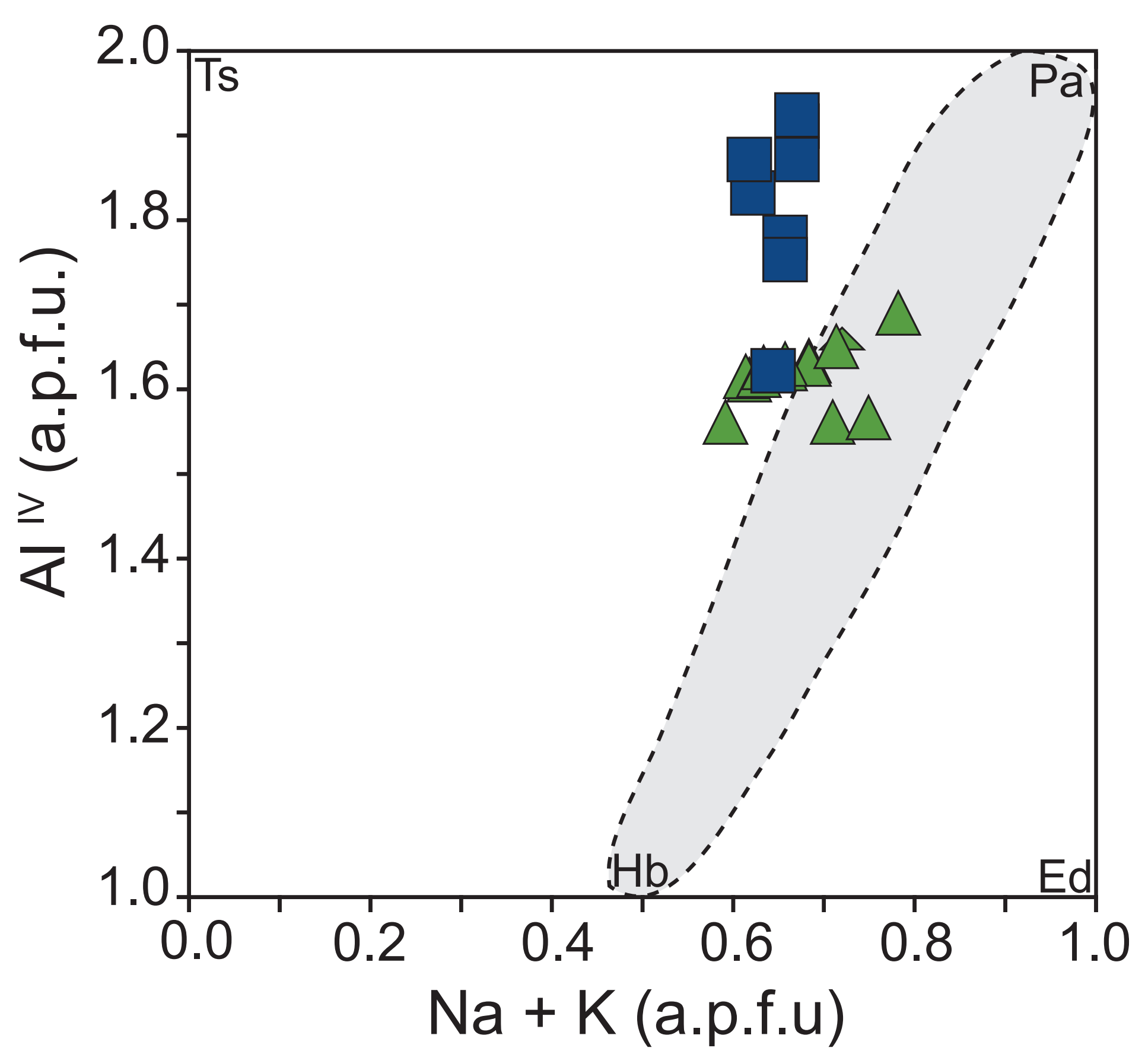

$\triangle$ Ty Lan

$\square$ Pont de Barel

Fig. 4 
Figure 5
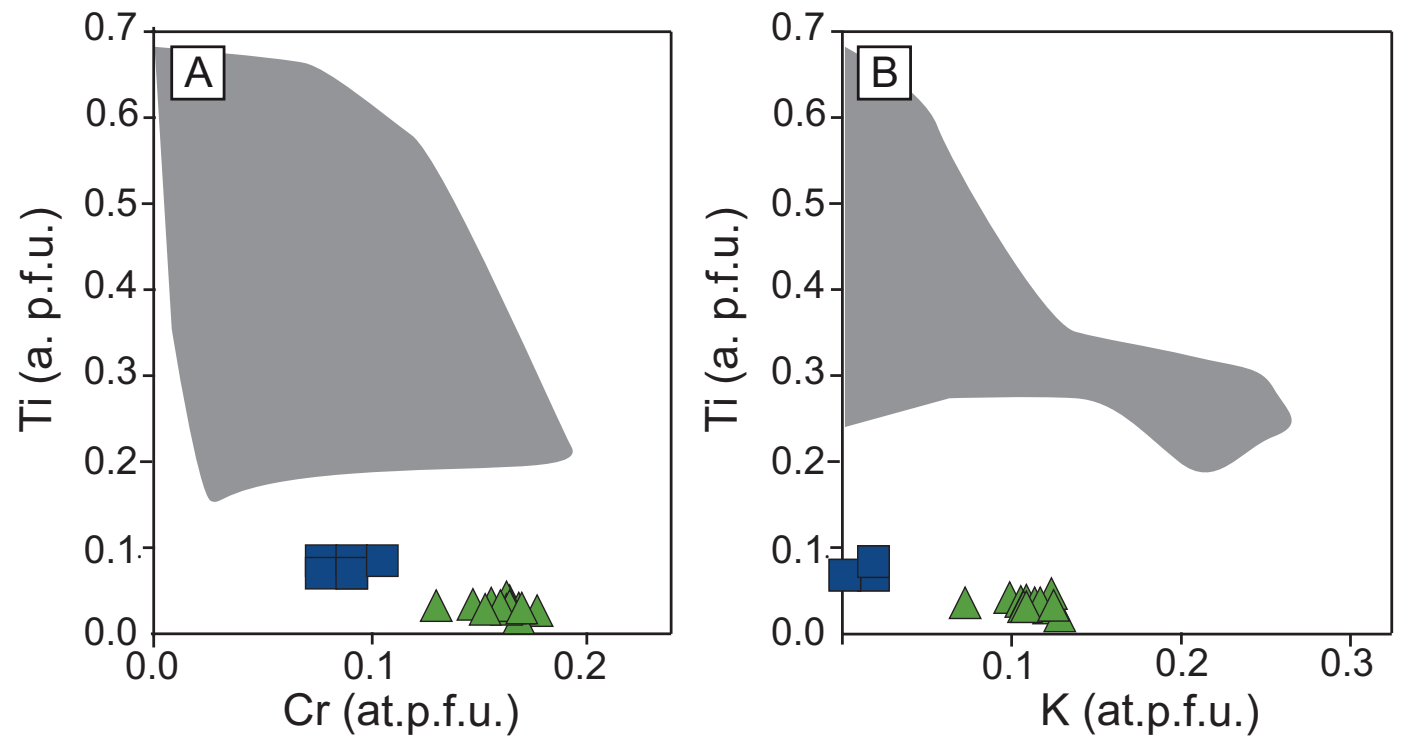

$\triangle$ Ty Lan $\square$ Pont de Barel

Fig. 5

Fig. 5 

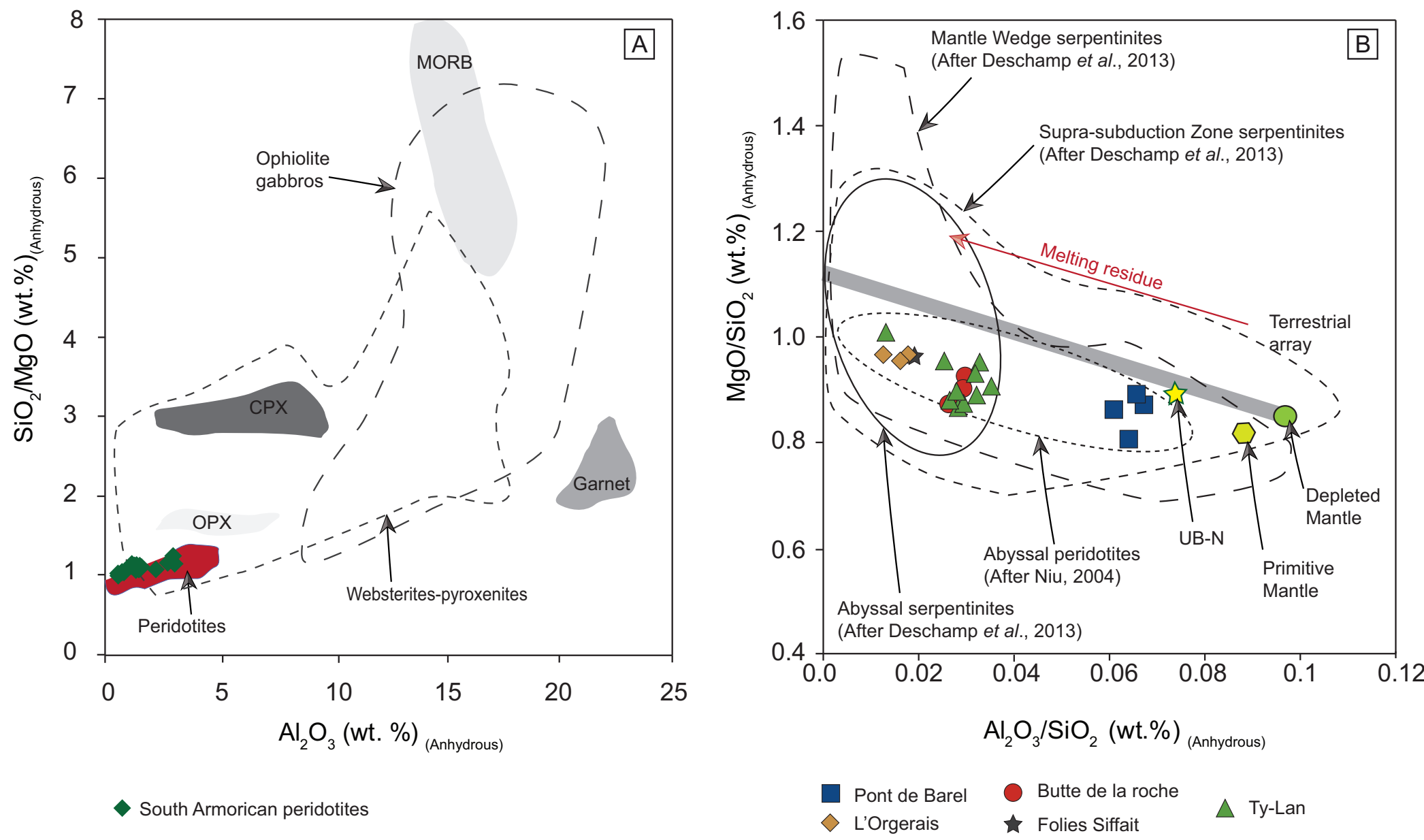

Fig. 6 
Figure 7
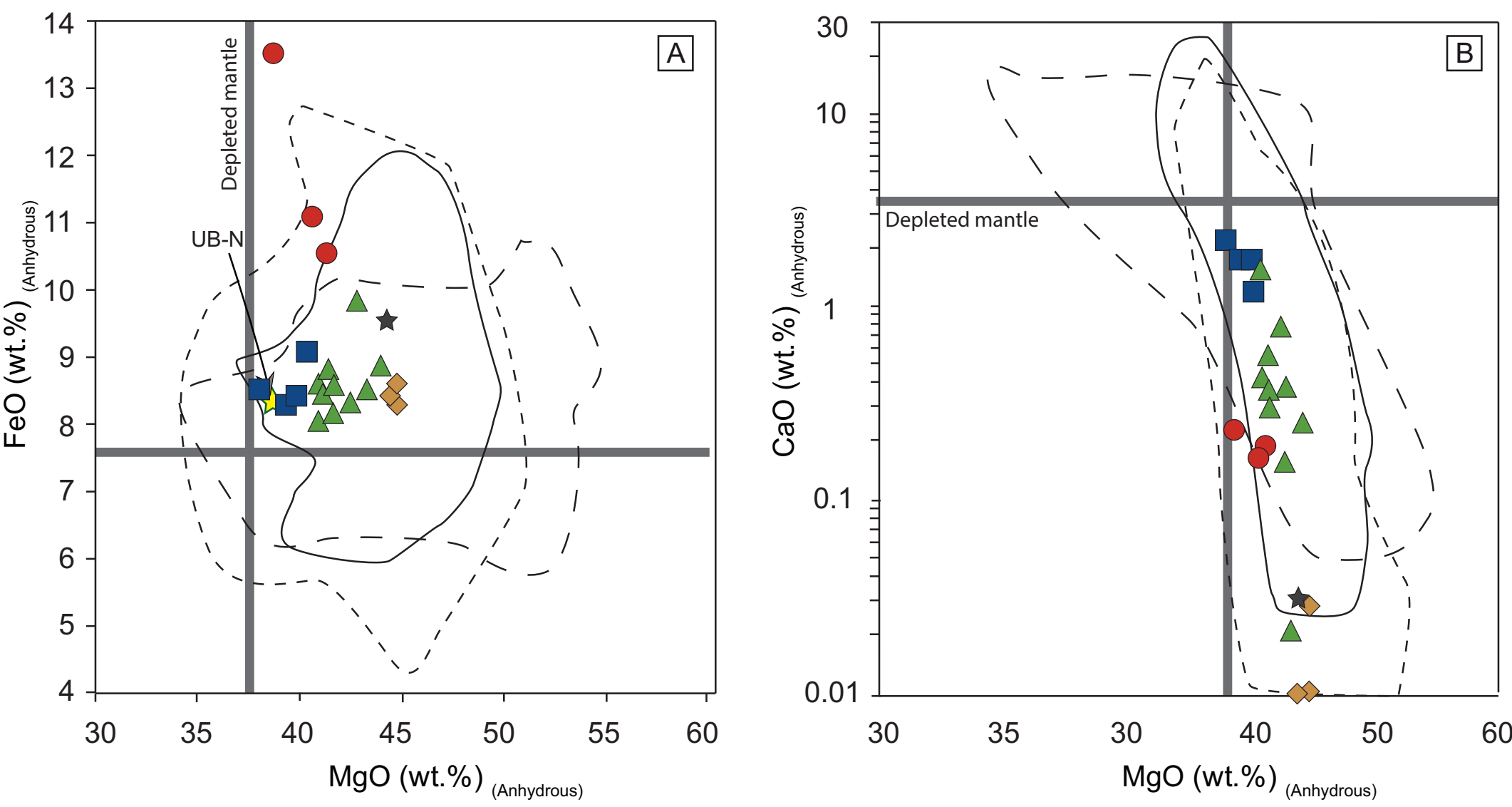

\begin{tabular}{ll}
- & - \\
\hline
\end{tabular}

Abyssal serpentinites

(After Deschamp et al., 2013)

$\begin{array}{lll}- & \neg & \text { Mantle Wedge serpentinites } \\ \llcorner & - & \text { (After Deschamp et al., 2013) }\end{array}$

Pont de Barel

$\diamond$ L'Orgerais
Butte de la roche

Folies Siffait
Ty-Lan

Fig. 7 

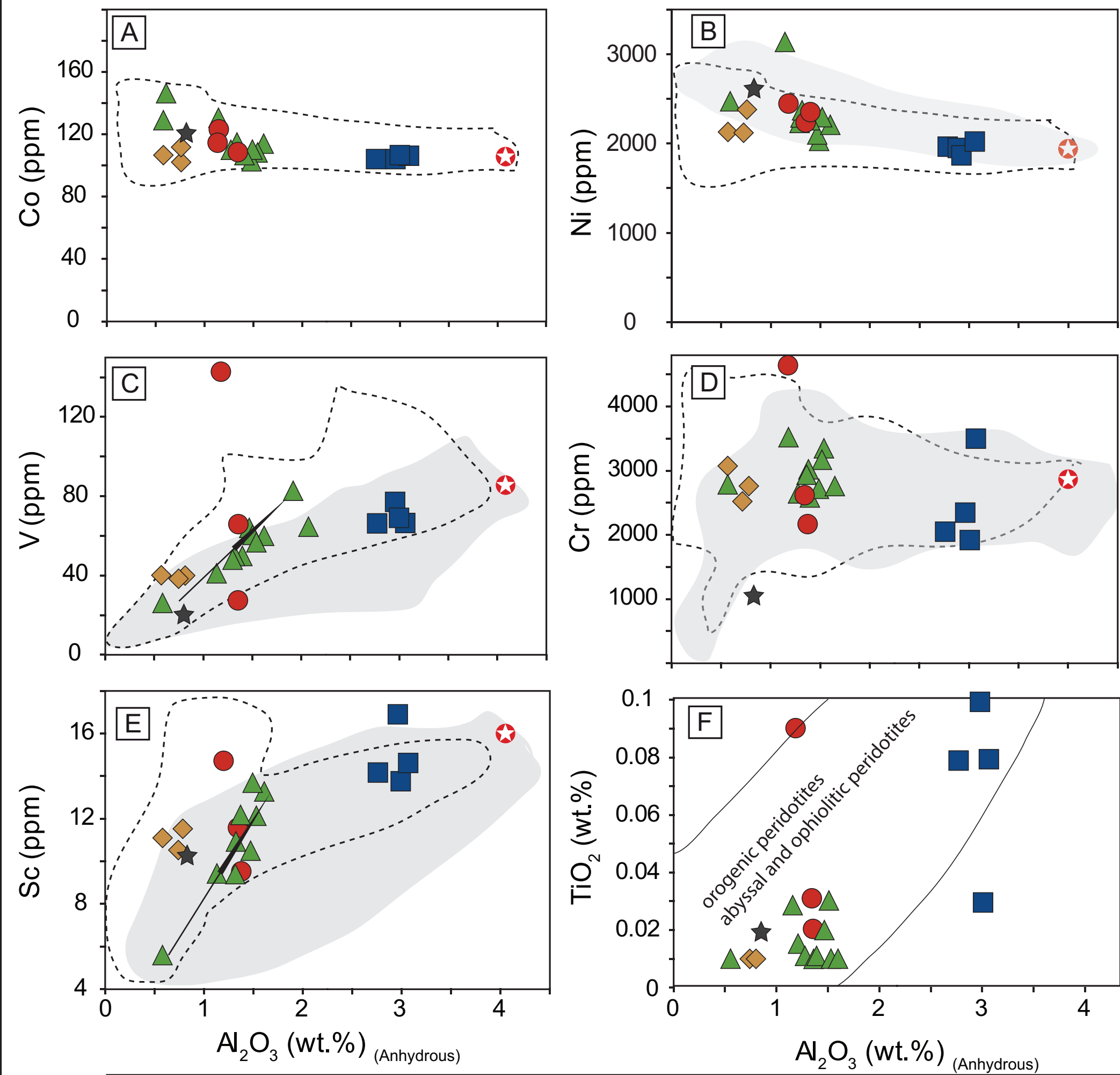

Pont de Barel

L'Orgerais

Butte de la roche

Folies Siffait

$\triangle$ Ty-Lan
Compostional fields

after Bodinier and Godard (2014)

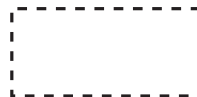

Abyssal peridotites

1

DMM compositions

(Workman and Hart, 2005)

Orogenic peridotites

Fig. 8 


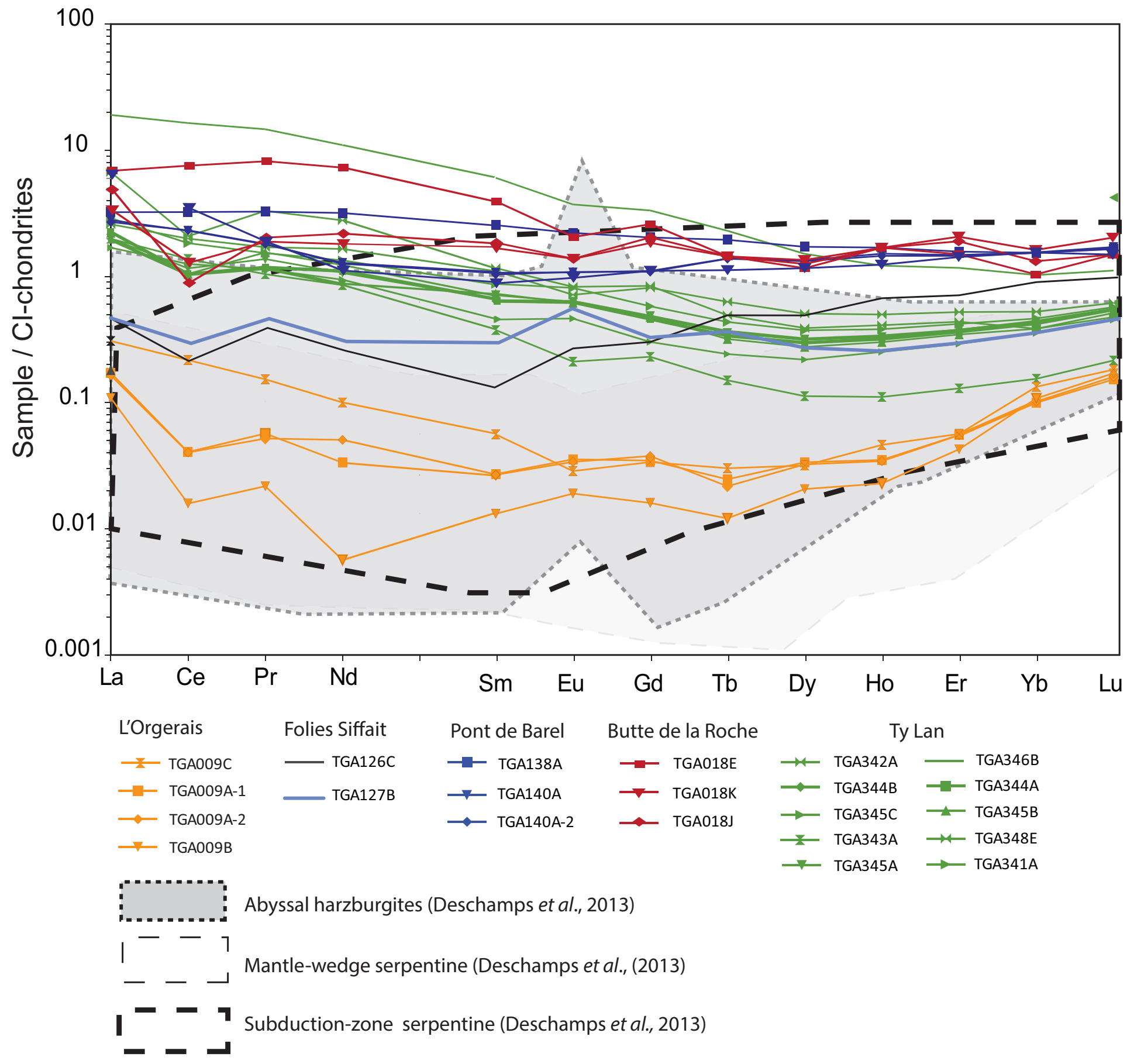

Fig. 9 
Figure 10
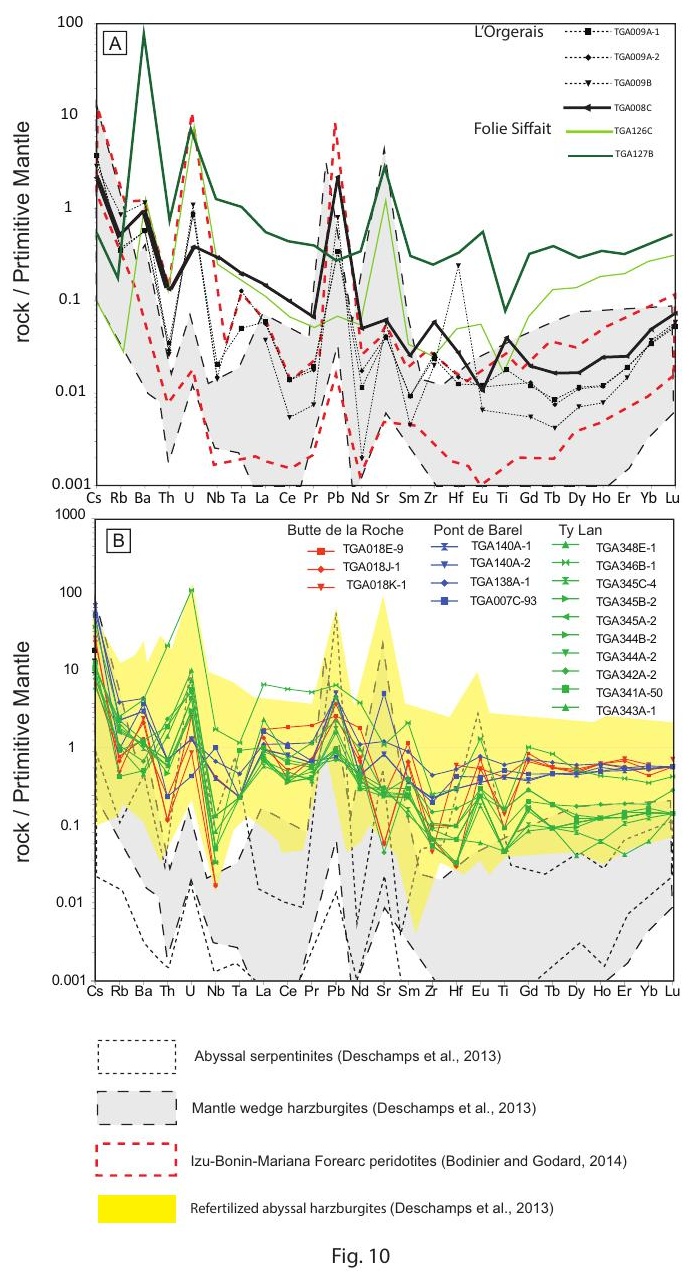

Abyssal serpentinites (Deschamps et al., 2013)

I Mantle wedge harzburgites (Deschamps et al., 2013)

1 - - -

1

Refertilized abyssal harzburgites (Deschamps et al., 2013)

Fig. 10 

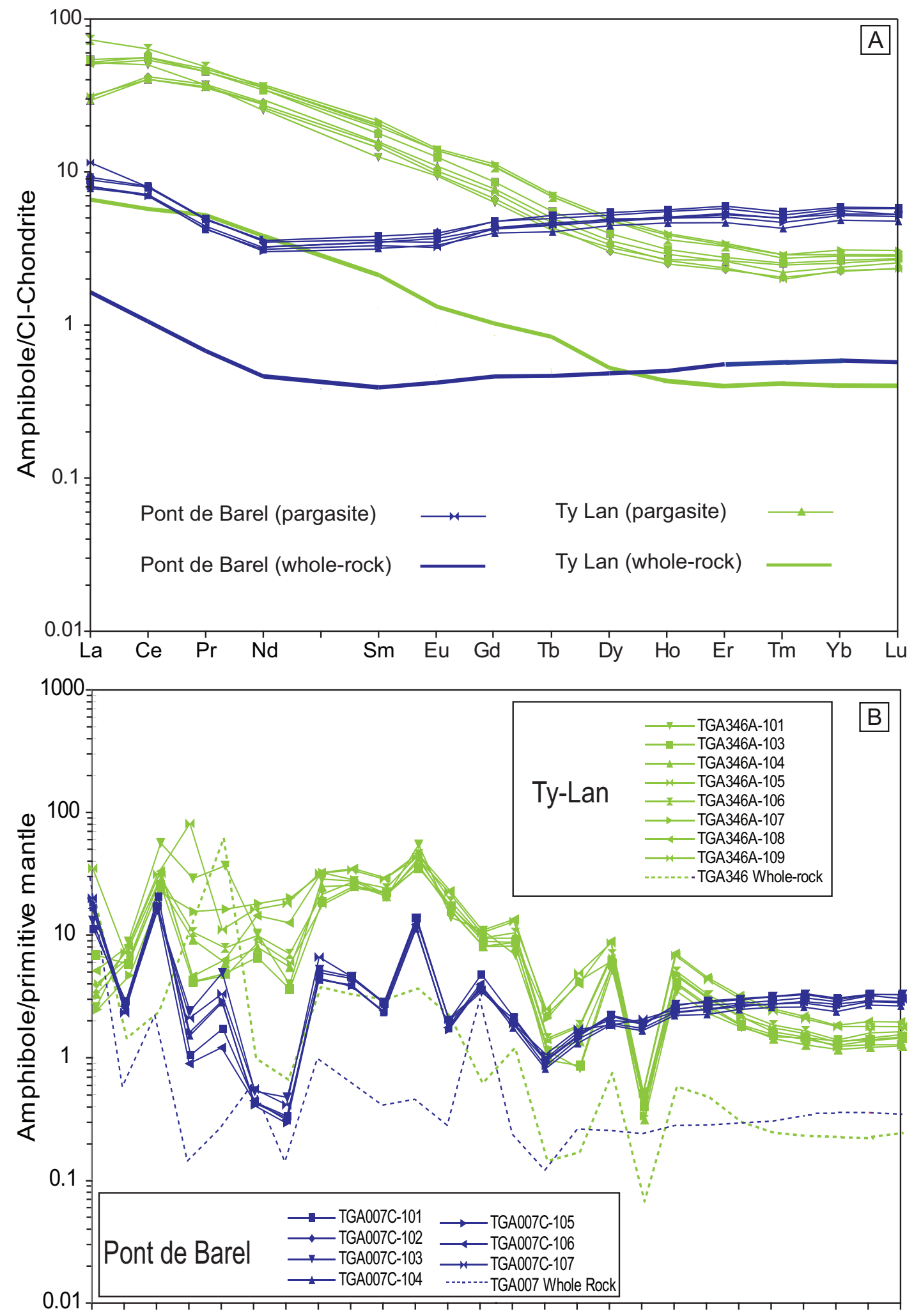

Cs Rb Ba Th U Nb Ta La Ce Pr Pb Nd Sr Sm Zr Hf Eu Ti Gd Tb Dy Ho Er Tm Yb Lu

Fig. 11 

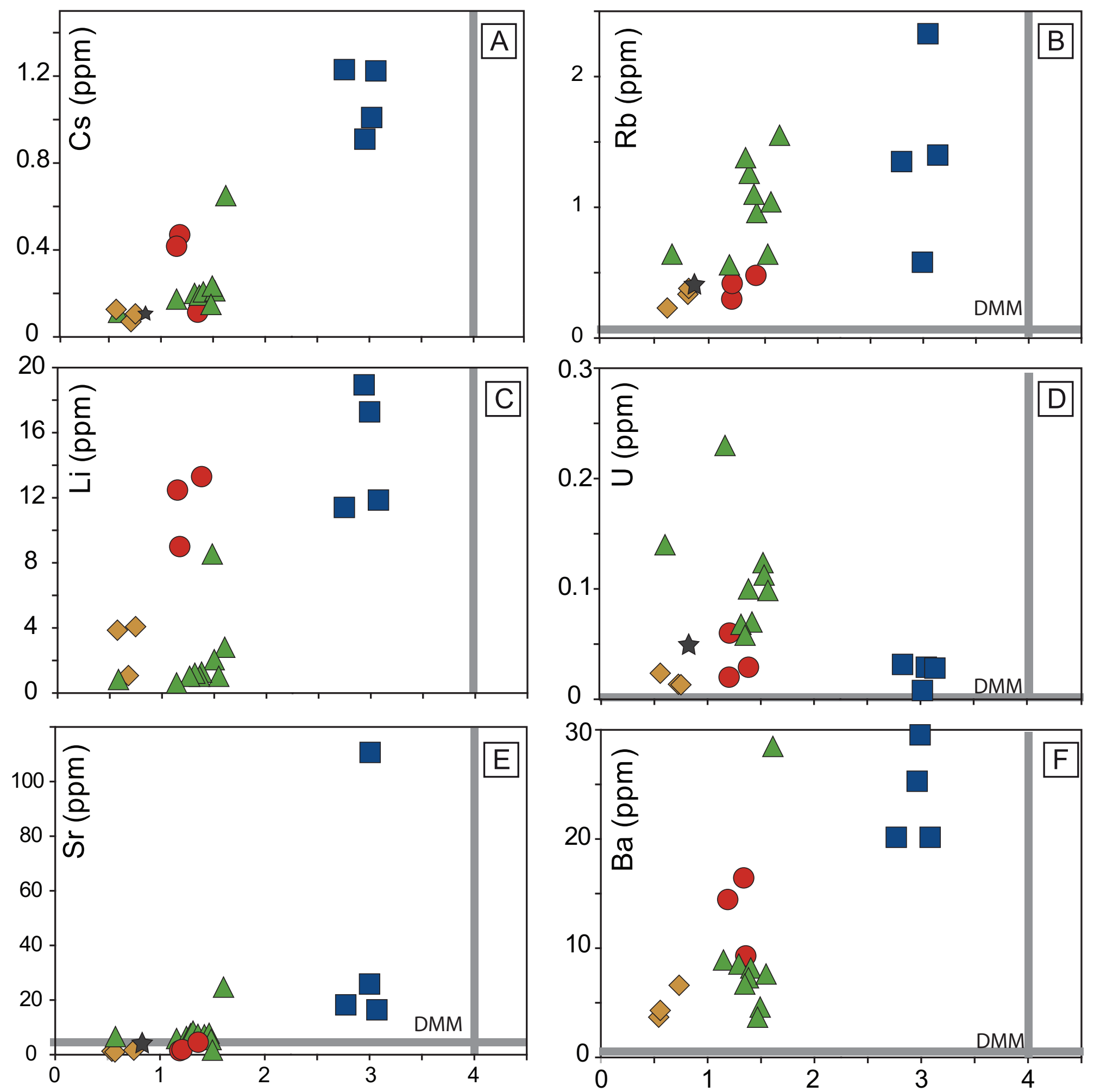

$$
\mathrm{Al}_{2} \mathrm{O}_{3} \text { (wt. \%) (Anhydrous) }
$$

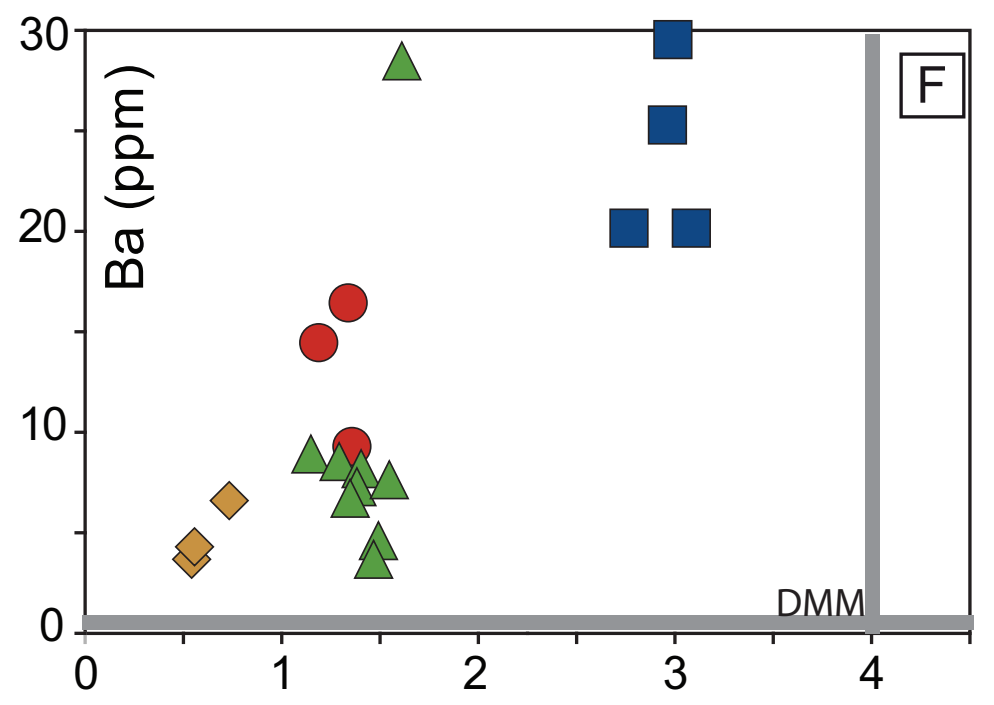

$\mathrm{Al}_{2} \mathrm{O}_{3}$ (wt. \%) (Anhydrous)

Pont de Barel $\bigcirc$ Butte de la roche $\diamond$ L'Orgerais $\quad$ Folies Siffait $\triangle$ Ty-Lan

Fig. 12 

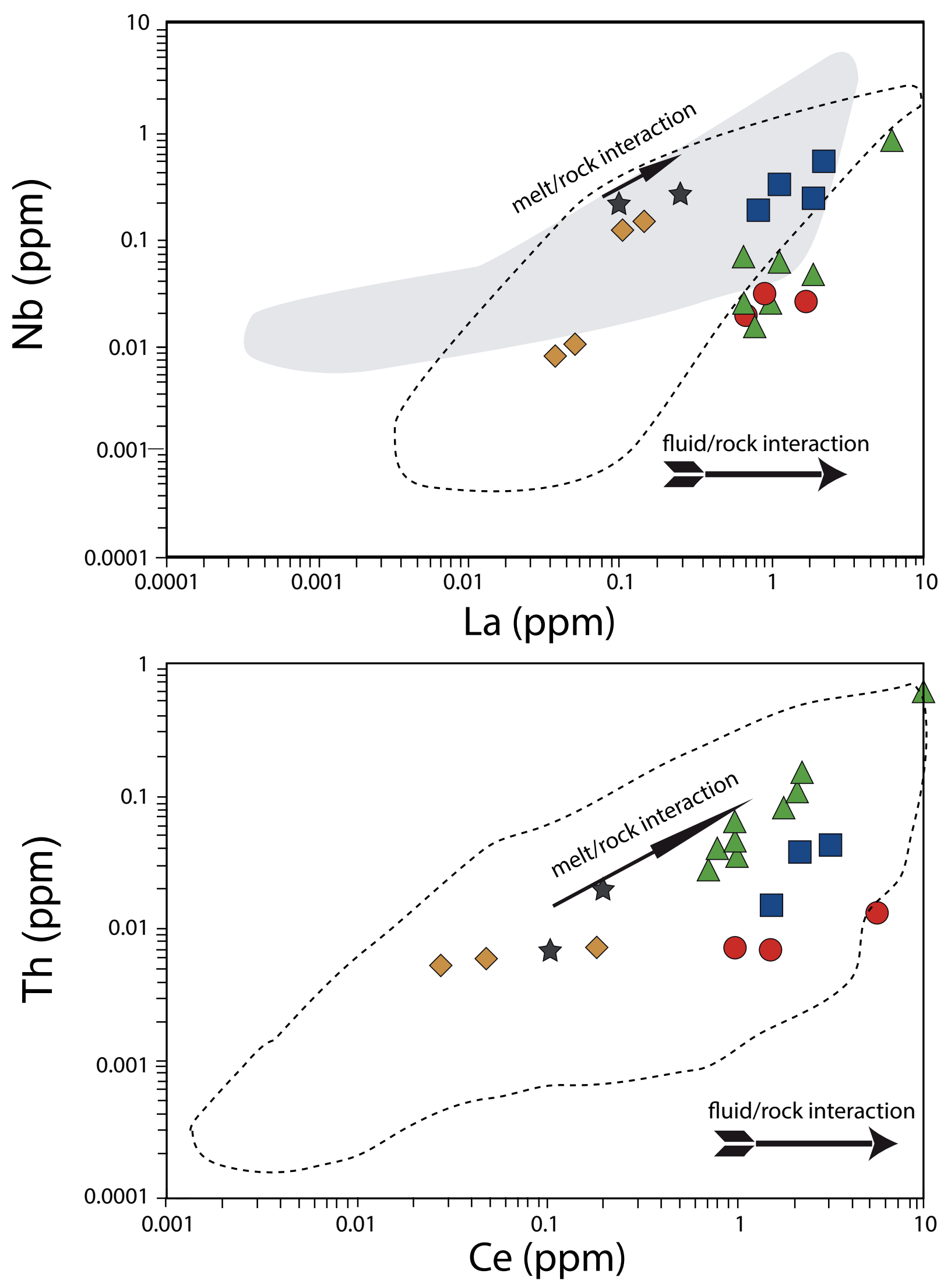

$\square$ Pont de Barel $\bigcirc$ Butte de la roche

$\diamond$ L'Orgerais $\quad \wedge$ Folies Siffait

Abyssal peridotites

$\triangle$ Ty-Lan

Orogenic peridotites

Fig. 13 

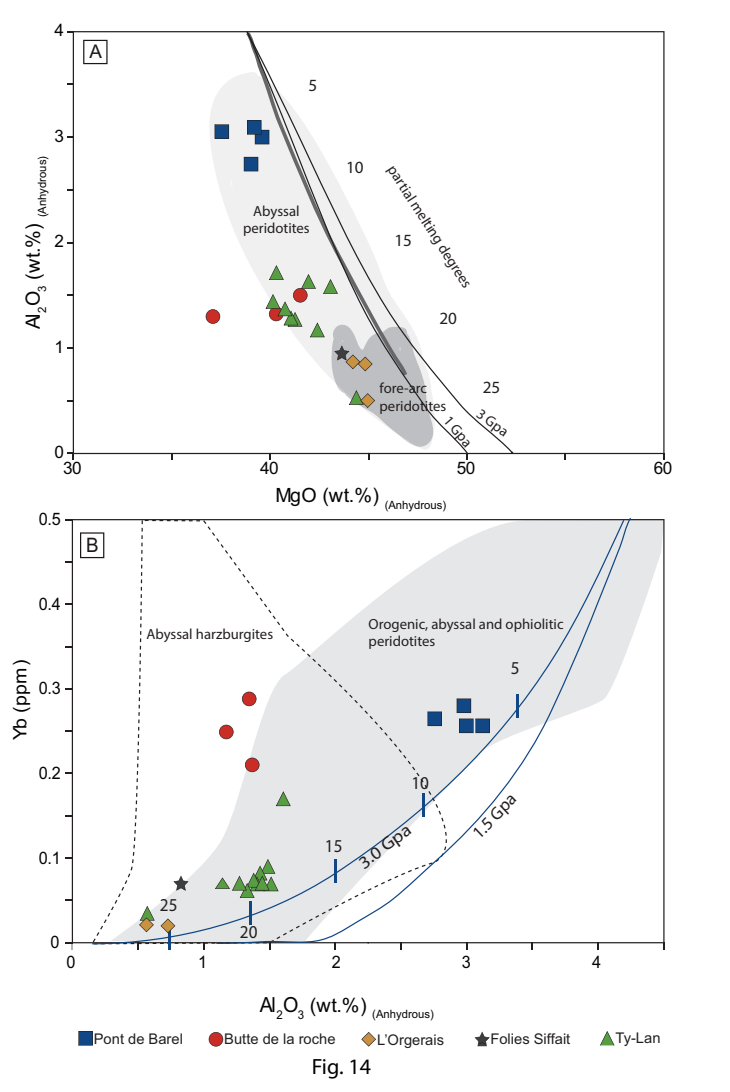

Figure 14

(1)

\section{Figure 14}

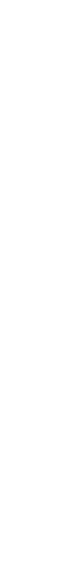

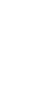

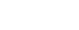

Fig. 14

.
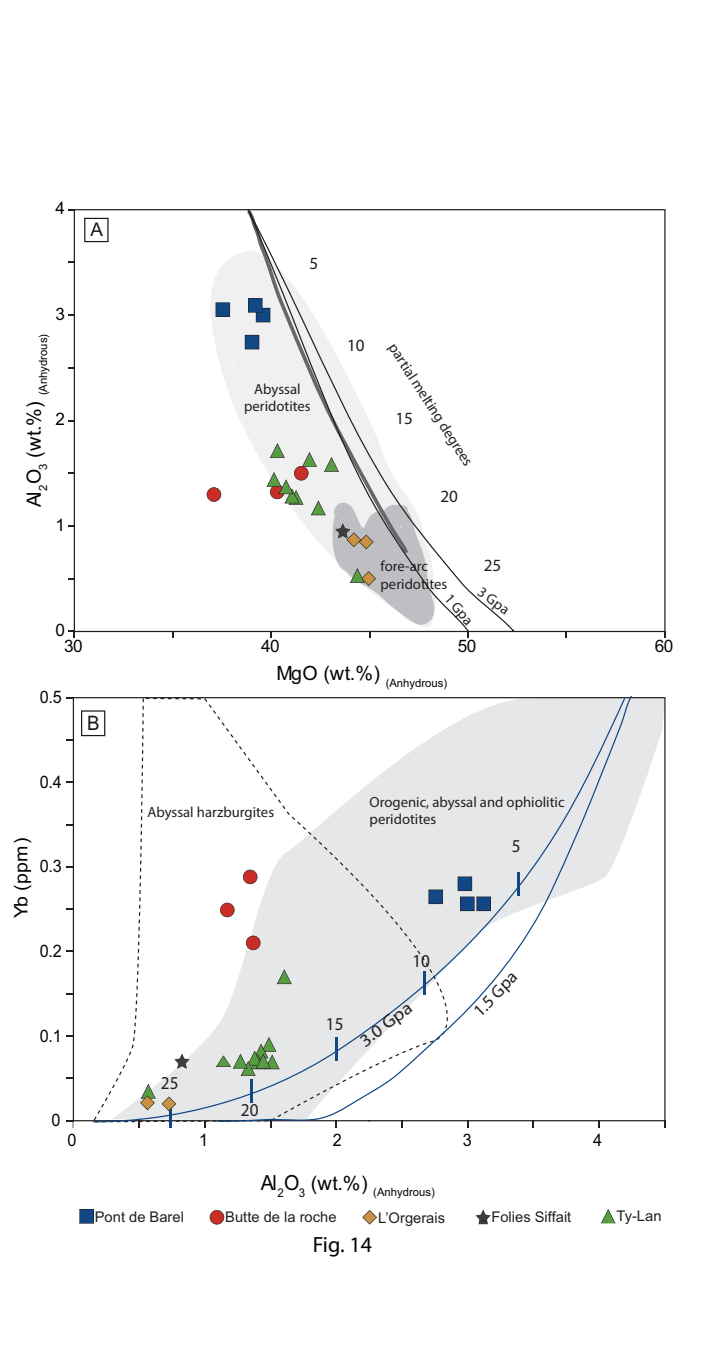
Table 1

\begin{tabular}{|c|c|c|c|c|c|c|c|c|c|c|c|c|c|c|c|c|c|c|c|c|c|}
\hline & \multirow{2}{*}{\multicolumn{15}{|c|}{ Ty-Lan }} & \multirow{2}{*}{\multicolumn{6}{|c|}{ Folies Siffait }} \\
\hline \multirow{2}{*}{$\begin{array}{c}\text { Representative electron } \\
\text { Locality } \\
\text { Sample name } \\
\text { Analysis number }\end{array}$} & & & & & & & & & & & & & & & & & & & & & \\
\hline & 17 & 18 & 19 & 2 & 20 & 3 & 31 & 32 & 33 & 34 & 35 & 4 & 46 & 5 & 7 & 5 & 6 & 22 & 21 & 3 & 4 \\
\hline Major elements (wt.\%) & & & & & & & & & & & & & & & & & & & & & \\
\hline $\mathrm{SiO}_{2}$ & 40.66 & 40.9 & 40.89 & 40.93 & 40.8 & 40.77 & 41.31 & 41.29 & 41.04 & 40.48 & 40.77 & 41.4 & 40.78 & 41.29 & 41.16 & 41.27 & 41.34 & 40.94 & 41.42 & 41.5 & 40.67 \\
\hline $\mathrm{TiO}_{2}$ & & 0.01 & & 0.04 & & 0.01 & 0.03 & & & 0.07 & 0.07 & 0.04 & 0.05 & & 0.01 & 0.02 & 0.03 & 0 & 0 & 0.03 & 0.03 \\
\hline $\mathrm{MnO}$ & 0.17 & 0.11 & 0.18 & 0.14 & 0.18 & 0.2 & 0.16 & 0.17 & 0.17 & 0.19 & 0.17 & 0.19 & 0.2 & 0.22 & 0.15 & 0.23 & 0.17 & 0.19 & 0.17 & 0.19 & 0.18 \\
\hline $\mathrm{FeO}$ & 10.34 & 9.54 & 10.75 & 9.18 & 9.64 & 9.68 & 9.49 & 10.07 & 9.46 & 10.12 & 9.68 & 9.36 & 10.65 & 10.07 & 9.52 & 10.62 & 10.61 & 10.69 & 10.78 & 10.73 & 10.89 \\
\hline $\mathrm{NiO}$ & 0.38 & 0.4 & 0.39 & 0.34 & 0.35 & 0.37 & 0.38 & 0.37 & 0.37 & 0.37 & 0.42 & 0.36 & 0.32 & 0.31 & 0.37 & 0.31 & 0.33 & 0.32 & 0.43 & 0.27 & 0.39 \\
\hline $\mathrm{MgO}$ & 48.87 & 49.58 & 48.59 & 49.93 & 49.5 & 49.55 & 50.13 & 49.54 & 49.51 & 49.47 & 49.65 & 49.49 & 48.16 & 48.79 & 49.41 & 48.13 & 48.38 & 48.46 & 48.7 & 48.77 & 48.85 \\
\hline Total & 100.41 & 100.6 & 100.88 & 100.57 & 100.53 & 100.6 & 101.58 & 101.45 & 100.59 & 100.79 & 100.82 & 100.85 & 100.21 & 100.73 & 100.64 & 100.63 & 100.91 & 100.63 & 101.52 & 101.54 & 101.06 \\
\hline $\mathrm{Mg}$ no & 89 & 90 & 89 & 91 & 90 & 90 & 90 & 90 & 90 & 90 & 90 & 90 & 89 & 90 & 90 & 89 & 89 & 89 & 89 & 89 & 89 \\
\hline
\end{tabular}

\begin{tabular}{cr}
$\mathrm{Mg} \mathrm{no}$ & 89 \\
\hline $\mathrm{Mg} \mathrm{no}=100^{*} \mathrm{MgO} /(\mathrm{MgO}+\mathrm{FeO})$
\end{tabular} 


\begin{tabular}{|c|c|c|c|c|c|c|c|c|c|c|c|c|c|c|c|c|c|c|c|c|c|c|c|c|c|c|c|c|c|c|}
\hline \multicolumn{31}{|c|}{ Representative electron microbrobe analyses of $\mathrm{Cr}$-spinel. } \\
\hline \multirow{3}{*}{$\begin{array}{l}\text { Locality } \\
\text { Sample name } \\
\text { Analysis number }\end{array}$} & \multirow{2}{*}{\multicolumn{7}{|c|}{$\begin{array}{c}\text { Pont de Barel } \\
\text { TGA007C }\end{array}$}} & \multirow{2}{*}{\multicolumn{9}{|c|}{$\begin{array}{c}\text { Butte de la Roche } \\
\text { TGA387A }\end{array}$}} & \multirow{2}{*}{\multicolumn{14}{|c|}{$\begin{array}{l}\text { L'Orgerais } \\
\text { TGA009C }\end{array}$}} \\
\hline & & & & & & & & & & & & & & & & & & & & & & & & & & & & & & \\
\hline & \multicolumn{7}{|c|}{$\begin{array}{lll}48 & 36 \quad 42 \\
\end{array}$} & 13 & 4 & 14 & 3 & 5 & 16 & 1 & 17 & 2 & 1 & 2 & 3 & 4 & 6 & 7 & 8 & 9 & 10 & 11 & 12 & 13 & 14 & 15 \\
\hline $\mathrm{SiO}_{2}$ & 0.13 & 0.13 & 0 & 0.03 & 0.06 & 2.14 & & & & 0 & 0.04 & 0 & 0.03 & 0.03 & 0 & & 0.04 & 0 & 0 & 0.04 & 0.08 & 0 & 0 & 0 & 0 & 0.09 & 0 & 0 & 0.05 & 0.05 \\
\hline $\mathrm{TiO}_{2}$ & 0.05 & 0.01 & 0 & 0.06 & 0.05 & 0.01 & 0.01 & 0.09 & 0.1 & 0.09 & 0.15 & 0.13 & 0.09 & 0.13 & 0.11 & 0.11 & 0.1 & 0.04 & 0.08 & 0.07 & 0.05 & 0.01 & 0 & 0.07 & 0.04 & 0.09 & 0.04 & 0.03 & 0.06 & 0.07 \\
\hline $\mathrm{Al}_{2} \mathrm{O}_{3}$ & 54.65 & 53.23 & 54.95 & 52.85 & 53.58 & 55.3 & 48.18 & 35.52 & 31.72 & 27.06 & 32.56 & 24.68 & 37.4 & 23.34 & 35.91 & 23.1 & 25.56 & 21.41 & 25.47 & 19.77 & 27.4 & 29.64 & 30.63 & 28.43 & 26.12 & 21.12 & 21.93 & 21.7 & 20.95 & 20.94 \\
\hline $\mathrm{Cr}_{2} \mathrm{O}_{3}$ & 12.37 & 12.34 & 7.95 & 12.18 & 12.04 & 10.32 & 12.57 & 29.97 & 33.28 & 37.05 & 32.85 & 39.21 & 27.82 & 40.69 & 29.31 & 41.17 & 42.69 & 46.32 & 43.07 & 40.52 & 39.47 & 37.02 & 37 & 38.38 & 40.9 & 45.94 & 46.39 & 46.18 & 45.83 & 46.24 \\
\hline $\mathrm{MnO}$ & 0.14 & 0.12 & 0.08 & 0.14 & 0.1 & 0.14 & 0.43 & 0.19 & 0.26 & 0.34 & 0.26 & 0.31 & 0.2 & 0.26 & 0.16 & 0.27 & 0.19 & 0.29 & 0.16 & 0.34 & 0.25 & 0.22 & 0.24 & 0.28 & 0.29 & 0.21 & 0.24 & 0.3 & 0.3 & 0.29 \\
\hline $\mathrm{FeO}$ & 16.82 & 15.44 & 14.56 & 15.74 & 15.67 & 14.77 & 19.1 & 20.43 & 21.98 & 23.34 & 21.76 & 24.39 & 19.44 & 24.27 & 20.01 & 24.98 & 20.67 & 22.63 & 20.82 & 28.78 & 21.91 & 21.11 & 21.16 & 21.21 & 22.23 & 22.98 & 21.74 & 22.25 & 22.54 & 22.8 \\
\hline $\mathrm{Fe}_{2} \mathrm{O}_{3}$ & 1.24 & 2.53 & 0.04 & 3.19 & 3.51 & 2.82 & 4.21 & 3.22 & 3.96 & 4.38 & 3.48 & 4.24 & 3.42 & 3.59 & 3.44 & 4.56 & 1.55 & 2.1 & 1.28 & 8.32 & 2.93 & 3.16 & 2.37 & 2.92 & 2.71 & 1.99 & 1.79 & 2.11 & 2.12 & 1.77 \\
\hline $\mathrm{NiO}$ & 0.32 & 0.33 & 0.39 & 0.37 & 0.34 & 0.34 & 0.33 & 0.2 & 0.12 & 0.15 & 0.16 & 0.06 & 0.14 & 0.01 & 0.15 & 0.1 & 0.02 & 0.06 & 0.02 & 0.02 & 0.07 & 0.01 & 0.12 & 0.04 & 0.09 & & & & & \\
\hline $\mathrm{MgO}$ & 16.35 & 17.36 & 18.06 & 17.49 & 17.98 & 18.21 & 17.26 & 12.93 & 11.95 & 10.75 & 12.01 & 9.75 & 13.8 & 9.21 & 13.37 & 9.4 & 11.04 & 9.42 & 10.69 & 8.61 & 11.09 & 11.93 & 11.59 & 11.62 & 10.53 & 9.1 & 10.03 & 9.79 & 9.28 & 9.02 \\
\hline Total & 100.96 & 99.28 & 97.98 & 99.16 & 100.17 & 99.46 & 100.44 & 99.4 & 99.5 & 98.87 & 99.83 & 98.63 & 98.99 & 98.04 & 99.12 & 99.25 & 100.46 & 100.42 & 100.46 & 99.02 & 100.65 & 100.27 & 101 & 100.31 & 100.49 & 99.79 & 100.55 & 100.46 & 99.29 & 99.65 \\
\hline $\mathrm{Mg} \#$ & 0.65 & 0.7 & 0.69 & 0.71 & 0.72 & 0.73 & 0.67 & 0.57 & 0.54 & 0.51 & 0.54 & 0.47 & 0.61 & 0.45 & 0.59 & 0.45 & 0.51 & 0.45 & 0.49 & 0.43 & 0.51 & 0.54 & 0.52 & 0.53 & 0.49 & 0.44 & 0.47 & 0.46 & 0.45 & 0.43 \\
\hline $\mathrm{Cr} \#$ & 0.13 & 0.13 & 0.09 & 0.13 & 0.13 & 0.11 & 0.15 & 0.36 & 0.41 & 0.48 & 0.4 & 0.52 & 0.33 & 0.54 & 0.35 & 0.54 & 0.53 & 0.59 & 0.53 & 0.58 & 0.49 & 0.46 & 0.45 & 0.48 & 0.51 & 0.59 & 0.59 & 0.59 & 0.59 & 0.6 \\
\hline
\end{tabular}

$\mathrm{Mg} \#=\mathrm{Mg} /(\mathrm{Mg}+\mathrm{Fe} 2+) ; \mathrm{Cr} \#=\mathrm{Cr} /(\mathrm{Cr}+\mathrm{Al}) ;$ Trivalent iron content calculated by assuming stoichiometry 


\begin{tabular}{|c|c|c|c|c|c|c|c|c|c|c|c|c|c|c|c|}
\hline \multicolumn{16}{|c|}{ Representative electron microprobe analyses of paragasite (wt \%) } \\
\hline $\begin{array}{l}\text { Locality } \\
\text { Sample name }\end{array}$ & & & & $\begin{array}{l}\text { ont de Bi } \\
\text { TGA007 }\end{array}$ & & & & \multicolumn{8}{|c|}{$\begin{array}{c}\text { Butte de la Roche } \\
\text { TGA346A }\end{array}$} \\
\hline Analysis number & 32 & 85 & 86 & 87 & 88 & 89 & 91 & 9 & 45 & 42 & 41 & 38 & 21 & 11 & 37 \\
\hline $\mathrm{SiO}_{2}$ & 42.96 & 44.35 & 44.14 & 43.71 & 44.32 & 45.03 & 43.83 & 44.79 & 45.22 & 44.54 & 44.77 & 44.59 & 44.64 & 45.06 & 44.81 \\
\hline $\mathrm{TiO}_{2}$ & 0.65 & 0.69 & 0.63 & 0.78 & 0.72 & 0.69 & 0.71 & 0.26 & 0.19 & 0.2 & 0.13 & 0.29 & 0.22 & 0.22 & 0.2 \\
\hline $\mathrm{Al}_{2} \mathrm{O}_{3}$ & 13.83 & 14.25 & 14.38 & 14.56 & 14.19 & 12.87 & 14.27 & 12.75 & 12.00 & 12.58 & 12.7 & 12.3 & 12.6 & 12.6 & 12.13 \\
\hline $\mathrm{Cr}_{2} \mathrm{O}_{3}$ & 0.83 & 0.75 & 0.74 & 0.79 & 0.82 & 0.78 & 0.93 & 1.49 & 1.57 & 1.51 & 1.51 & 1.47 & 1.46 & 1.28 & 1.522 \\
\hline $\mathrm{MnO}$ & 0.09 & 0.09 & 0.08 & 0.06 & 0.01 & 0.02 & 0.08 & 0.08 & 0.08 & 0.04 & 0.07 & 0.04 & 0.03 & 0.09 & 0.1 \\
\hline $\mathrm{FeO} *$ & 0.37 & 1.67 & 0.79 & 0.77 & 2.06 & 2 & 0.76 & 1.40 & 1.42 & 1.3 & 0.82 & 1.18 & 0.73 & 0.77 & 0.48 \\
\hline $\mathrm{Fe}_{2} \mathrm{O}_{3} *$ & 4.65 & 2.8 & 3.92 & 4.12 & 2.36 & 2.34 & 4.16 & 2.83 & 2.57 & 2.77 & 3.24 & 3.08 & 3.14 & 3.6 & 3.9 \\
\hline $\mathrm{NiO}$ & 0.19 & 0.09 & 0.13 & 0.14 & 0.05 & 0.05 & 0.08 & 0.12 & 0.03 & 0.15 & 0.11 & 0.05 & 0.11 & 0.17 & 0.08 \\
\hline $\mathrm{MgO}$ & 17.97 & 18.01 & 18.05 & 18.11 & 17.89 & 18.39 & 17.97 & 18.46 & 18.82 & 18.34 & 18.59 & 18.64 & 18.5 & 18.56 & 19.1 \\
\hline $\mathrm{CaO}$ & 12.62 & 12.57 & 12.63 & 12.57 & 12.53 & 12.77 & 12.59 & 12.56 & 12.69 & 12.55 & 12.1 & 12.69 & 12.57 & 12.46 & 12.12 \\
\hline $\mathrm{Na}_{2} \mathrm{O}$ & 2.59 & 2.65 & 2.62 & 2.73 & 2.66 & 2.59 & 2.58 & 2.46 & 2.41 & 2.31 & 2.23 & 2.39 & 2.31 & 2.35 & 2.21 \\
\hline $\mathrm{K}_{2} \mathrm{O}$ & 0.1 & 0.11 & 0.08 & 0.1 & 0.1 & 0.08 & 0.11 & 0.52 & 0.6 & 0.61 & 0.61 & 0.6 & 0.57 & 0.43 & 0.6 \\
\hline $\mathrm{H}_{2} \mathrm{O}^{+}$ & 2.12 & 2.13 & 2.13 & 2.12 & 2.13 & 2.13 & 2.13 & 2.12 & 2.12 & 2.12 & 2.13 & 2.12 & 2.13 & 2.13 & 2.13 \\
\hline Total & 98.97 & 100.18 & 100.3 & 100.59 & 99.83 & 99.76 & 100.23 & 99.87 & 99.78 & 99.07 & 99.04 & 99.56 & 99.05 & 99.83 & 99.41 \\
\hline \multicolumn{16}{|l|}{ Structural formulae } \\
\hline $\mathrm{Si}(\mathrm{T})$ & 6.14 & 6.24 & 6.2 & 6.13 & 6.26 & 6.36 & 6.17 & 6.33 & 6.404 & 6.353 & 6.367 & 6.336 & 6.354 & 6.362 & 6.356 \\
\hline $\mathrm{Al}(\mathrm{T})$ & 1.86 & 1.76 & 1.8 & 1.87 & 1.74 & 1.64 & 1.83 & 1.66 & 1.594 & 1.646 & 1.632 & 1.662 & 1.646 & 1.635 & 1.643 \\
\hline $\mathrm{T}$ (sum) & 8 & 8 & 8 & 8 & 8 & 8 & 8 & 8 & 8 & 8 & 8 & 8 & 8 & 7.999 & 8 \\
\hline$\overline{(\mathrm{C}) \mathrm{Ti}}$ & 0.07 & 0.07 & 0.07 & 0.08 & 0.08 & 0.07 & 0.08 & 0.028 & 0.02 & 0.022 & 0.014 & 0.031 & 0.024 & 0.024 & 0.022 \\
\hline (C)Al & 0.47 & 0.6 & 0.58 & 0.54 & 0.62 & 0.5 & 0.54 & 0.466 & 0.409 & 0.47 & 0.497 & 0.407 & 0.469 & 0.469 & 0.386 \\
\hline (C) $\mathrm{Cr}$ & 0.09 & 0.08 & 0.08 & 0.09 & 0.09 & 0.09 & 0.1 & 0.167 & 0.176 & 0.17 & 0.17 & 0.166 & 0.164 & 0.143 & 0.171 \\
\hline$(\mathrm{C}) \mathrm{Fe}^{3+}$ & 0.5 & 0.3 & 0.41 & 0.44 & 0.25 & 0.25 & 0.44 & 0.302 & 0.274 & 0.298 & 0.347 & 0.329 & 0.337 & 0.382 & 0.416 \\
\hline (C)Ni & 0.02 & 0.01 & 0.01 & 0.02 & 0.01 & 0.01 & 0.01 & 0.014 & 0.004 & 0.018 & 0.011 & 0.005 & 0.013 & 0.02 & 0.009 \\
\hline$(\mathrm{C}) \mathrm{Fe}^{2+}$ & 0.02 & 0.16 & 0.07 & 0.05 & 0.2 & 0.21 & 0.06 & 0.13 & 0.143 & 0.123 & 0.02 & 0.114 & 0.067 & 0.054 & \\
\hline (C)Mg & 3.83 & 3.78 & 3.78 & 3.79 & 3.76 & 3.87 & 3.77 & 3.893 & 3.973 & 3.899 & 3.942 & 3.948 & 3.926 & 3.908 & 3.997 \\
\hline $\mathrm{C}$ (sum) & 5 & 5 & 5 & 5 & 5 & 5 & 5 & 5 & 4.999 & 5 & 5.001 & 5 & 5 & 5 & 5.001 \\
\hline (B) $\mathrm{Mn}^{2+}$ & 0.01 & 0.01 & 0.01 & 0.01 & 0 & 0 & 0.01 & 0.009 & 0.01 & 0.005 & 0.009 & 0.006 & 0.004 & 0.011 & 0.013 \\
\hline (B) $\mathrm{Fe}^{2+}$ & 0.02 & 0.04 & 0.03 & 0.04 & 0.05 & 0.03 & 0.03 & 0.035 & 0.025 & 0.033 & 0.079 & 0.026 & 0.02 & 0.038 & 0.057 \\
\hline (B)Ca & 1.93 & 1.9 & 1.9 & 1.89 & 1.9 & 1.93 & 1.9 & 1.905 & 1.925 & 1.918 & 1.844 & 1.932 & 1.917 & 1.885 & 1.842 \\
\hline (B) $\mathrm{Na}$ & 0.04 & 0.06 & 0.07 & 0.06 & 0.06 & 0.04 & 0.06 & 0.051 & 0.04 & 0.044 & 0.069 & 0.037 & 0.058 & 0.066 & 0.045 \\
\hline $\mathrm{B}$ (sum) & 2 & 2 & 2 & 2 & 2 & 2 & 2 & 2 & 2 & 2 & 2.001 & 2.001 & 1.999 & 2 & 2 \\
\hline (A) $\mathrm{Na}$ & 0.68 & 0.67 & 0.65 & 0.68 & 0.67 & 0.67 & 0.64 & 0.626 & 0.623 & 0.596 & 0.547 & 0.624 & 0.581 & 0.579 & 0.563 \\
\hline (A)K & 0.02 & 0.02 & 0.01 & 0.02 & 0.02 & 0.01 & 0.02 & 0.094 & 0.108 & 0.11 & 0.112 & 0.109 & 0.105 & 0.078 & 0.109 \\
\hline $\mathrm{A}$ (sum) & 0.7 & 0.69 & 0.66 & 0.7 & 0.69 & 0.69 & 0.66 & 0.72 & 0.731 & 0.706 & 0.659 & 0.733 & 0.686 & 0.657 & 0.672 \\
\hline (A) $\mathrm{Na}+$ (B) $\mathrm{Na}$ & 0.718 & 0.723 & 0.713 & 0.743 & 0.728 & 0.708 & 0.704 & 0.677 & 0.663 & 0.64 & 0.616 & 0.661 & 0.639 & 0.645 & 0.608 \\
\hline
\end{tabular}


Table 4
Click here to download Table: Table 4.docx

Table 4

\begin{tabular}{|c|c|c|c|c|c|c|c|c|c|c|c|c|c|c|c|c|c|c|c|c|c|}
\hline \multicolumn{5}{|c|}{ 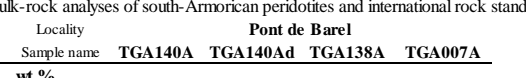 } & \multirow{2}{*}{\multicolumn{3}{|c|}{ 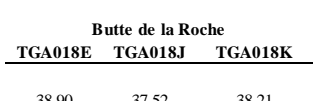 }} & \multicolumn{3}{|c|}{ 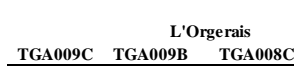 } & TGA009A & \multirow{2}{*}{\multicolumn{10}{|c|}{ 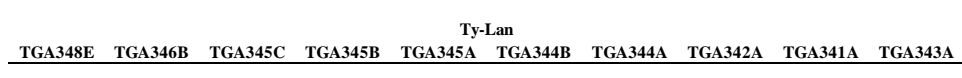 }} \\
\hline${ }^{1.1 .} \mathrm{SiO}_{2}$ & 40.11 & 40.17 & & & & & & & & & & & & & & & & & & & \\
\hline $\begin{array}{l}\mathrm{Sl}_{2} \\
\mathrm{TiO}_{2}\end{array}$ & $\begin{array}{l}\begin{array}{l}40.11 \\
0.080\end{array} \\
0\end{array}$ & $\begin{array}{l}40.11 \\
0.081\end{array}$ & $\begin{array}{l}41.51 \\
0.109\end{array}$ & 0.098 & $\begin{array}{l}38.90 \\
0.025\end{array}$ & $\begin{array}{l}3.10 \\
0.090\end{array}$ & 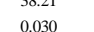 & $\begin{array}{r}4.0000 \\
0.000\end{array}$ & NA & $\begin{array}{r}7.04000 \\
0.00\end{array}$ & $\begin{aligned} 0.000 \\
0.00\end{aligned}$ & $\begin{aligned} 30,12 \\
0.026\end{aligned}$ & $\begin{aligned} 3,308 \\
0.062\end{aligned}$ & $\begin{aligned} 3,30 \\
0.010\end{aligned}$ & $\begin{aligned} 3,83 \\
0.010\end{aligned}$ & 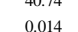 & $\begin{array}{l}39.88 \\
0.014\end{array}$ & $\begin{aligned} 3,111 \\
0.01\end{aligned}$ & $\begin{array}{l}40.13 \\
0.032\end{array}$ & $\begin{array}{l}39.47 \\
0015\end{array}$ & $\begin{array}{l}38.02 \\
0.012\end{array}$ \\
\hline $\begin{array}{l}\mathrm{H}_{2} \mathrm{O}_{3} \\
\mathrm{~A}_{2}\end{array}$ & $\begin{array}{l}2.0060 \\
2.44\end{array}$ & $\begin{array}{l}0.011 \\
2.72\end{array}$ & $\begin{array}{l}2.109 \\
2.68\end{array}$ & $\begin{array}{l}2.0858 \\
2.65\end{array}$ & $\begin{array}{l}0.028 \\
1.18\end{array}$ & 1.05 & 1.11 & 0.05 & $\begin{array}{l}\text { N.A. } \\
\text { N.A. }\end{array}$ & 0.068 & 0.51 & $\begin{array}{l}0.020 \\
0.99\end{array}$ & $\begin{array}{l}0.020 \\
1.42\end{array}$ & $\begin{array}{l}0.010 \\
1.13\end{array}$ & $\begin{array}{l}0.010 \\
1.11\end{array}$ & $\begin{array}{l}0.017 \\
1.21\end{array}$ & $\begin{array}{l}0.014 \\
1.32\end{array}$ & 1.21 & $\begin{array}{l}\text {. } 1.32 \\
1.35\end{array}$ & 1.28 & 0.051 \\
\hline $\mathrm{FeO}$ & 7.24 & 7.40 & 7.47 & 7.98 & 9.21 & 11.52 & 9.44 & 7.33 & N.A. & 7.39 & 7.27 & 8.43 & 7.56 & 7.42 & 7.25 & 6.92 & 7.05 & 7.16 & 7.52 & 7.20 & $\begin{array}{l}8.01 \\
8.18\end{array}$ \\
\hline $\begin{array}{l}\text { Mno } \\
\text { MeO }\end{array}$ & $\begin{array}{l}0.099 \\
346.6\end{array}$ & $\begin{array}{l}0.099 \\
35.2\end{array}$ & $\begin{array}{l}0.10 \\
33.8\end{array}$ & $\begin{array}{l}0.09 \\
3594\end{array}$ & $\begin{array}{l}0.08 \\
36.1\end{array}$ & $\begin{array}{l}0.10 \\
329\end{array}$ & $\begin{array}{l}0.08 \\
346\end{array}$ & $\begin{array}{l}0.07 \\
38.8\end{array}$ & $\begin{array}{l}\text { N.A. } \\
\text { N.A. }\end{array}$ & $\begin{array}{l}0.08 \\
39.1\end{array}$ & $\begin{array}{l}0.07 \\
396.6\end{array}$ & $\begin{array}{l}0.10 \\
33.7\end{array}$ & $\begin{array}{l}0.11 \\
359\end{array}$ & $\begin{array}{l}0.10 \\
332\end{array}$ & $\begin{array}{l}0.10 \\
335\end{array}$ & $\begin{array}{l}0.10 \\
355\end{array}$ & $\begin{array}{l}0.08 \\
3.35\end{array}$ & $\begin{array}{l}0.09 \\
3.5\end{array}$ & $\begin{array}{l}0.08 \\
380\end{array}$ & $\begin{array}{l}0.09 \\
3.76\end{array}$ & $\begin{array}{l}0.08 \\
337\end{array}$ \\
\hline 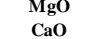 & $\begin{array}{l}34.6 \\
1.54\end{array}$ & $\begin{array}{l}35.2 \\
1.56\end{array}$ & $\begin{array}{l}33.8 \\
1.98\end{array}$ & $\begin{array}{l}35.4 \\
1.05\end{array}$ & $\begin{array}{l}36.1 \\
0.17\end{array}$ & $\begin{array}{l}32.9 \\
0.20\end{array}$ & $\begin{array}{l}34.6 \\
0.15\end{array}$ & $\begin{array}{l}38.8 \\
0.01\end{array}$ & $\begin{array}{l}\text { N.A. } \\
\text { N.A. }\end{array}$ & $\begin{array}{l}39.1 \\
0.01\end{array}$ & $\begin{array}{l}39.6 \\
0.03\end{array}$ & $\begin{array}{l}36.7 \\
0.14\end{array}$ & $\begin{array}{l}35.9 \\
1.36\end{array}$ & $\begin{array}{l}35.2 \\
0.47\end{array}$ & $\begin{array}{l}35.3 \\
0.22\end{array}$ & $\begin{array}{l}35.2 \\
0.36\end{array}$ & $\begin{array}{l}35.3 \\
0.26\end{array}$ & $\begin{array}{l}35.1 \\
0.30\end{array}$ & $\begin{array}{l}38.0 \\
0.02\end{array}$ & $\begin{array}{l}36.7 \\
0.06\end{array}$ & $\begin{array}{l}37.7 \\
0.21\end{array}$ \\
\hline $\mathrm{Na}_{2} \mathrm{O}$ & $<0.003$ & $<0.003$ & $\begin{array}{l}1.1080 \\
0.207\end{array}$ & $\begin{array}{l}0.092 \\
0.092\end{array}$ & $<0.003$ & 0.009 & 0.009 & ${ }_{0.003}$ & N.A. & $\begin{array}{l}0.01 \\
<0.003\end{array}$ & $\begin{array}{l}0.03 \\
0.003\end{array}$ & 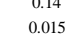 & $\begin{array}{l}1.166 \\
0.099\end{array}$ & 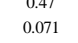 & $\begin{array}{l}0.29 \\
0.063\end{array}$ & $\begin{array}{l}.0 .06 \\
0.059\end{array}$ & $\begin{array}{l}0.06 \\
0.021\end{array}$ & $\begin{array}{l}\begin{array}{l}0.00 \\
0.206\end{array} \\
0\end{array}$ & $\begin{array}{l}0.02 \\
0.005\end{array}$ & $\begin{array}{l}0.06 \\
0.010\end{array}$ & $\begin{array}{l}0.21 \\
0.007\end{array}$ \\
\hline $\mathrm{K}_{2} \mathrm{O}$ & 0.032 & 0.032 & 0.103 & $<0.014$ & $<0.014$ & 0.026 & 0.025 & $<0.014$ & N.A. & $<0.014$ & 80.014 & $<0.014$ & 0.037 & 0.036 & 0.033 & 0.0222 & 0.024 & $\begin{array}{l}0.020 \\
0.220\end{array}$ & N.A. & $<0.014$ & $<0.014$ \\
\hline $\begin{array}{l}\mathrm{P}_{2} \mathrm{O}_{5} \\
\mathrm{O}\end{array}$ & $\begin{array}{l}<.013 \\
11.75\end{array}$ & $\begin{array}{l}<0.013 \\
11.57\end{array}$ & $\begin{array}{l}0.017 \\
11.57\end{array}$ & $\begin{array}{l}0.025 \\
1214\end{array}$ & $\begin{array}{l}0.013 \\
1243\end{array}$ & $\begin{array}{l}0.020 \\
15323\end{array}$ & $\begin{array}{l}0.019 \\
1.528\end{array}$ & $\begin{array}{l}6.013 \\
12.43\end{array}$ & $\begin{array}{l}\text { N.A. } \\
\text { N.A }\end{array}$ & $\begin{array}{r}<0.013 \\
1243\end{array}$ & $\begin{array}{l}<.013 \\
1097\end{array}$ & $\begin{array}{l}0.036 \\
1384\end{array}$ & $\begin{array}{l}0.044 \\
1274\end{array}$ & $\begin{array}{l}0.014 \\
151.14\end{array}$ & $\begin{array}{l}0.020 \\
151\end{array}$ & $\begin{array}{l}0.020 \\
14580\end{array}$ & $\begin{array}{r}<0.013 \\
1527\end{array}$ & $\begin{array}{l}0.014 \\
0.1550\end{array}$ & 0.019 & 0.018 & $\begin{array}{l}0.045 \\
1440\end{array}$ \\
\hline $\mathrm{ppm}$ & 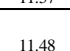 & 1186 & & & & & & & & & & & & & & & & & & 13.71 & 1430 \\
\hline${ }_{\mathrm{Be}}^{\mathrm{He}}$ & $\begin{array}{l}1.148 \\
<0.24\end{array}$ & 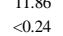 & $\begin{array}{l}r 7.28 \\
<0.24\end{array}$ & $\begin{array}{l}18.97 \\
<0.24\end{array}$ & $\begin{array}{l}13.35 \\
0.47\end{array}$ & $\begin{array}{l}9.03 \\
0.61\end{array}$ & $\begin{array}{l}1.1778 \\
<.2 .24\end{array}$ & 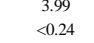 & $\begin{array}{l}5.47 \\
<0.24\end{array}$ & $\begin{array}{c}0.83 \\
<0.24\end{array}$ & $\begin{array}{l}3.86 \\
<.024\end{array}$ & $\begin{array}{l}0.052 \\
<0.24\end{array}$ & $\begin{array}{l}2.282 \\
1.40\end{array}$ & $\begin{array}{l}0.022 \\
<0.24\end{array}$ & $\begin{array}{l}0.099 \\
<0.24\end{array}$ & $\begin{array}{l}1.03 \\
<0.24\end{array}$ & $\begin{array}{c}1.111 \\
<0.24\end{array}$ & $\begin{array}{l}1.15 \\
<0.24\end{array}$ & $\begin{array}{l}2.05 \\
<0.24\end{array}$ & $\begin{array}{l}8.58 \\
<.0 .24\end{array}$ & $\begin{array}{l}0.85 \\
<0_{0.22}\end{array}$ \\
\hline sc & 12.6 & 13.0 & 12.2 & 14.9 & $\begin{array}{l}0.47 \\
10.0\end{array}$ & $\begin{array}{l}0.01 \\
12.5\end{array}$ & $\begin{array}{l}8.04 \\
8.0\end{array}$ & $\begin{array}{l}9.24 \\
9.7\end{array}$ & $\begin{array}{l}9.24 \\
9.3\end{array}$ & $\begin{array}{l}0.24 \\
9.3\end{array}$ & $\begin{array}{l}10.24 \\
10.0\end{array}$ & $\begin{array}{l}8.24 \\
8.2\end{array}$ & $\begin{array}{l}1.140 \\
11.5\end{array}$ & 9.4 & 9.0 & $\begin{array}{l}10.44 \\
10.3\end{array}$ & $\begin{array}{l}0.24 \\
10.4\end{array}$ & $\begin{array}{l}10.44 \\
10.4\end{array}$ & $\begin{array}{l}12.24 \\
12.1\end{array}$ & $\begin{array}{l}12.44 \\
12.1\end{array}$ & $\begin{array}{l}0.24 \\
4.8\end{array}$ \\
\hline $\mathrm{v}$ & 66.6 & 66.5 & 68.4 & 76.9 & 27.4 & 142.9 & 66.0 & $\begin{array}{l}39.2 \\
2708\end{array}$ & $\begin{array}{l}34.8 \\
3725\end{array}$ & $\begin{array}{l}38.1 \\
3525\end{array}$ & 39.3 & 40.6 & 59.0 & 50.1 & 48.3 & 51.8 & 56.3 & 50.0 & 59.0 & 62.6 & 24.4 \\
\hline Сo & $\begin{array}{l}2050 \\
99\end{array}$ & $\begin{array}{l}20074 \\
100\end{array}$ & 1918 & $\begin{array}{l}2360 \\
97\end{array}$ & $\begin{array}{l}2183 \\
100\end{array}$ & $\begin{array}{l}4647 \\
108\end{array}$ & $\begin{array}{l}2597 \\
114\end{array}$ & $\begin{array}{l}2780 \\
106\end{array}$ & $\begin{array}{l}2353 \\
107\end{array}$ & $\begin{array}{l}2536 \\
96\end{array}$ & $\begin{array}{l}3045 \\
101\end{array}$ & $\begin{array}{l}3519 \\
123\end{array}$ & $\begin{array}{l}2730 \\
106\end{array}$ & $\begin{array}{l}2882 \\
108\end{array}$ & $\begin{array}{r}2622 \\
104\end{array}$ & $\begin{array}{l}3038 \\
102\end{array}$ & $\begin{array}{l}3321 \\
101\end{array}$ & $\begin{array}{l}2599 \\
103\end{array}$ & $\begin{array}{l}3260 \\
97\end{array}$ & $\begin{array}{l}2704 \\
103\end{array}$ & $\begin{array}{l}2800 \\
100\end{array}$ \\
\hline $\mathrm{Ni}$ & 2004 & 2042 & 1947 & 1997 & $\begin{array}{l}100 \\
22250\end{array}$ & $\begin{array}{l}108 \\
2452\end{array}$ & $\begin{array}{r}114 \\
2366\end{array}$ & $\begin{array}{l}106 \\
2374\end{array}$ & 2390 & $\begin{array}{l}96 \\
2096\end{array}$ & $\begin{array}{l}101 \\
2153\end{array}$ & $\begin{array}{l}123 \\
3103\end{array}$ & $\begin{array}{l}106 \\
2200\end{array}$ & $\begin{array}{l}108 \\
2313\end{array}$ & $\begin{array}{l}104 \\
2225\end{array}$ & $\begin{array}{l}102 \\
22221\end{array}$ & $\begin{array}{l}101 \\
2289\end{array}$ & $\begin{array}{l}103 \\
2274\end{array}$ & 2001 & $\begin{array}{l}103 \\
2045\end{array}$ & $\begin{array}{c}122 \\
2449\end{array}$ \\
\hline $\mathrm{Zn}$ & 53 & 52 & 53 & 46 & 49 & 74 & 55 & 52 & 68 & 51 & 37 & 53 & 37 & 41 & 39 & 40 & 48 & 46 & 41 & 38 & 59 \\
\hline $\begin{array}{l}\text { Ga } \\
\text { Rb }\end{array}$ & $\begin{array}{l}2.55 \\
1.37\end{array}$ & 2.53 & $\begin{array}{r}2.93 \\
2.24\end{array}$ & $\begin{array}{l}2.85 \\
0.08\end{array}$ & $\begin{array}{l}1.36 \\
0.947\end{array}$ & $\begin{array}{l}1.90 \\
044\end{array}$ & $\begin{array}{l}1.39 \\
<030\end{array}$ & $\begin{array}{l}0.72 \\
0.35\end{array}$ & $\begin{array}{l}0.55 \\
0.55\end{array}$ & $\begin{array}{l}0.67 \\
0.64\end{array}$ & $\begin{array}{l}0.63 \\
<30307\end{array}$ & $\begin{array}{l}1.37 \\
0.37\end{array}$ & $\begin{array}{l}1.73 \\
1.73\end{array}$ & $\begin{array}{l}1.23 \\
1.23\end{array}$ & 1.23 & $\begin{array}{l}1.37 \\
0.37\end{array}$ & 1.55 & 1.32 & $\begin{array}{l}1.59 \\
0.065\end{array}$ & $\begin{array}{l}1.47 \\
60303\end{array}$ & $\begin{array}{l}0.71 \\
0.72\end{array}$ \\
\hline Sr & 18.32 & 18.23 & 20.6 & $\begin{array}{l}0.38 \\
16.91\end{array}$ & $\begin{array}{l}0.4 / 7 \\
5.38\end{array}$ & $\begin{array}{l}0.41 \\
6.57\end{array}$ & $\begin{array}{l}5.0 .30 \\
5.85\end{array}$ & $\begin{array}{l}\text {. } 135 \\
1.39\end{array}$ & $\begin{array}{l}1.53 \\
1.24\end{array}$ & $\begin{array}{l}0.34 \\
1.32\end{array}$ & $\begin{array}{l}6.30707 \\
0.87\end{array}$ & $\begin{array}{l}0.56 \\
5.86\end{array}$ & $\begin{array}{l}1.53 \\
23.84\end{array}$ & $\begin{array}{l}1.26 \\
6.13\end{array}$ & $\begin{array}{l}1.38 \\
5.90\end{array}$ & $\begin{array}{l}\text {. } \\
5.40\end{array}$ & $\begin{array}{l}1.02 \\
5.23\end{array}$ & $\begin{array}{l}1.100 \\
5.19\end{array}$ & $\begin{array}{l}0.05 \\
0.99\end{array}$ & $\begin{array}{l}0.0307 \\
6.73\end{array}$ & $\begin{array}{l}.0 .62 \\
6.87\end{array}$ \\
\hline $\mathrm{Y}$ & 2.41 & 2.42 & 2.71 & 2.39 & 0.04 & 5.16 & 4,42 & 0.21 & 0.04 & 0.25 & 0.06 & 1.16 & 2.23 & 0.41 & 0.56 & $\begin{array}{l}0.618 \\
0.61\end{array}$ & 0.60 & 0.62 & 0.78 & 0.61 & $\begin{array}{l}6.87 \\
0.17\end{array}$ \\
\hline $\mathrm{Zr}$ & 2.51 & 2.58 & 4.81 & 2.04 & 1.29 & 0.68 & 0.47 & 0.91 & $<0.30$ & 0.90 & $<0.30$ & 1.111 & 2.61 & 0.56 & 0.71 & 0.67 & 0.95 & 0.92 & 1.54 & 0.57 & 0.71 \\
\hline${ }_{c}$ & $\begin{array}{l}0.24 \\
1.24\end{array}$ & & 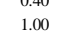 & $\begin{array}{l}0.05 \\
0.91\end{array}$ & $\begin{array}{l}0.25 \\
0.12\end{array}$ & $\begin{array}{l}0.03 \\
0.43\end{array}$ & $\begin{array}{l}0.02 \\
0.47\end{array}$ & $\begin{array}{l}0.20 \\
0.12\end{array}$ & $\begin{array}{l}0.0101 \\
0.09\end{array}$ & $\begin{array}{l}0.21 \\
0.07\end{array}$ & $\begin{array}{l}0.01 \\
0.12\end{array}$ & $\begin{array}{l}0.05 \\
0.17\end{array}$ & $\begin{array}{l}1.03 \\
0.65\end{array}$ & $\begin{array}{l}0.03 \\
0.19\end{array}$ & $\begin{array}{l}0.02 \\
0.19\end{array}$ & $\begin{array}{l}0.022 \\
0.14\end{array}$ & $\begin{array}{l}0.03 \\
0.21\end{array}$ & $\begin{array}{l}0.03 \\
0.20\end{array}$ & $\begin{array}{l}0.08 \\
0.14\end{array}$ & $\begin{array}{l}0.03 \\
0.23\end{array}$ & 0.08 \\
\hline Ba & 20.31 & 20.22 & 29.75 & $\begin{aligned} 25.24 \\
2\end{aligned}$ & 8.92 & 14.57 & 16.13 & 6.57 & 8.07 & 6.53 & 3.98 & 8.58 & 28.48 & 6.72 & 8.48 & 7.71 & 7.64 & 7.53 & 4.61 & 3.49 & $\begin{array}{l}0.11 \\
3.15\end{array}$ \\
\hline La & 0.64 & 0.66 & 0.76 & 1.12 & 1.18 & 0.92 & 0.70 & 0.07 & $<0.03$ & 0.10 & 0.04 & 1.59 & 4.51 & 0.40 & 0.52 & 0.47 & 0.46 & 0.53 & 0.61 & 0.69 & 0.47 \\
\hline $\begin{array}{l}\mathrm{Ce} \\
\mathrm{Pe}\end{array}$ & $\begin{array}{l}1.42 \\
0172\end{array}$ & $\begin{array}{l}1.41 \\
0.171\end{array}$ & $\begin{array}{l}1.98 \\
0.310\end{array}$ & $\begin{array}{l}1.85 \\
0.182\end{array}$ & $\begin{array}{l}3.24 \\
0.524\end{array}$ & $\begin{array}{l}0.69 \\
0.194\end{array}$ & $\begin{array}{l}0.90 \\
0.177\end{array}$ & $\begin{array}{l}0.08 \\
0.029\end{array}$ & $\begin{array}{c}c_{0.05} \\
\end{array}$ & $\begin{array}{l}0.12 \\
0.032\end{array}$ & $<0.05$ & $\begin{array}{l}1.27 \\
0.27\end{array}$ & $\begin{array}{ll}10.05 \\
1\end{array}$ & 0.77 & 0.06 & 0.711 & $\begin{array}{l}0.63 \\
0.110\end{array}$ & 0.64 & $\begin{array}{l}1.22 \\
1.26\end{array}$ & $\begin{array}{l}1.12 \\
1.42\end{array}$ & 0.84 \\
\hline $\mathrm{Nd}$ & 0.59 & 0 & $\begin{array}{l}1.49 \\
1\end{array}$ & 0 & 2.41 & 1.01 & 0.88 & $<0.09$ & $<0.09$ & 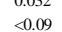 & $<0$ & 1.30 & 5.13 & $\begin{array}{l}0.0606 \\
0.04\end{array}$ & 0.57 & 0 & 0.40 & 0.51 & 0.77 & 0.63 & 0.0999 \\
\hline $\mathrm{Sm}$ & 0.14 & 0.15 & 0.39 & 0.16 & 0.49 & 0.29 & 0.27 & $<0.01$ & $<0.01$ & $\langle 0.01$ & $<0.01$ & 0.18 & 0.91 & 0.07 & 0.11 & 0.11 & 0.10 & 0.09 & 0.16 & 0.0 .13 & $\begin{array}{l}0.40 \\
0.06\end{array}$ \\
\hline Еu & 0.063 & 0.062 & 0.128 & 0.071 & 0.1118 & 0.089 & 0.0855 & $<0.0022$ & $<0.002$ & $<0.002$ & $<0.002$ & 0.048 & 0.216 & 0.027 & 0.036 & 0.037 & 0.037 & 136 & 0.041 & 0.047 & 0.012 \\
\hline Gd & $\begin{array}{l}0.230 \\
0.025\end{array}$ & $\begin{array}{l}0.233 \\
0.025\end{array}$ & $\begin{array}{l}0.477 \\
0.07\end{array}$ & $\begin{array}{l}0.2606 \\
0.04\end{array}$ & $\begin{array}{l}0.348 \\
0.060\end{array}$ & $\begin{array}{l}0.42 \\
0\end{array}$ & $\begin{array}{l}0.3060 \\
0.06\end{array}$ & $\begin{array}{r}0.000 \\
0.00\end{array}$ & $\begin{array}{c}0.008 \\
<000\end{array}$ & $\begin{aligned} 0.0008 \\
0.08\end{aligned}$ & 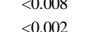 & $\begin{array}{l}0.137 \\
0.01\end{array}$ & $\begin{array}{l}0.684 \\
0.086\end{array}$ & $\begin{array}{l}0.020 \\
0.000\end{array}$ & $\begin{array}{l}0.088 \\
0.018\end{array}$ & $\begin{array}{l}0.1000 \\
0.01\end{array}$ & $\begin{array}{l}0.0998 \\
0.04\end{array}$ & $\begin{array}{l}0.043 \\
0.014\end{array}$ & $\begin{array}{l}0.167 \\
0102\end{array}$ & 0.1919 & $\begin{array}{l}0.047 \\
0.066\end{array}$ \\
\hline Dy & 0.34 & 0.35 & 0.43 & 0.35 & 0.36 & 0.37 & 0.39 & $<0.02$ & $<0.02$ & $<0.02$ & ${ }_{60.02}$ & 0.10 & 0.38 & 0.06 & 0.07 & 0.08 & 0.0 & 08 & .13 & 0.09 & $\begin{array}{l}0.0066 \\
0.03\end{array}$ \\
\hline Ho & 0.082 & 0.086 & 0.096 & 0.085 & 0.002 & 0.104 & 0.100 & 0.003 & $<0.0022$ & 0.004 & $<0.0022$ & 0.023 & 0.069 & 0.014 & 0.017 & 0.019 & 0.019 & 0.018 & 0.028 & 0.022 & 0.006 \\
\hline 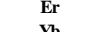 & $\begin{array}{l}0.241 \\
0.24\end{array}$ & 0.245 & $\begin{array}{l}0.260 \\
0.056\end{array}$ & $\begin{array}{l}0.262 \\
0.268\end{array}$ & 0.268 & $\begin{array}{l}0.317 \\
0.94\end{array}$ & $\begin{array}{l}0.3939 \\
0.398\end{array}$ & $<.007$ & 0.007 & 0.006 & 0.009 & 0.072 & $\begin{array}{l}0.1933 \\
0.19\end{array}$ & 0.098 & 0.057 & 0.063 & $\begin{array}{l}0.062 \\
0.072\end{array}$ & & 0.0866 & $\begin{array}{l}0.070 \\
0.008\end{array}$ & 0.021 \\
\hline 10 & 0.04 & 0.004 & 0.004 & 0.044 & 0 & 0.04 & 0.05 & 0 & 0.000 & 0.000 & 0.000 & 0.010 & 0 & 0010 & 0 & 0 & 0.040 & 0 & 0 & 0.010 & $\begin{array}{l}0.028 \\
0.025\end{array}$ \\
\hline HF & 0.097 & 0.098 & 0.162 & 0.094 & 0.037 & 0.42 & 0.016 & 0.014 & 0.074 & 0.014 & $<0.01$ & 0.030 & 0.094 & 0.010 & 0.014 & 0.017 & 0.025 & 0.021 & 0.050 & 0.012 & $\begin{array}{l}0.0009 \\
0.019\end{array}$ \\
\hline Ta & 0.0100 & 0.010 & 0.019 & $<0.007$ & 0.010 & $<0.007$ & $<0.007$ & $<0.007$ & $<0.007$ & 0.008 & $<0.007$ & $<0.007$ & 0.054 & 0.009 & $<0.007$ & $<0.007$ & $<0.007$ & $<0.007$ & 0.013 & 0.036 & 0.012 \\
\hline & 0.01 & & & $\begin{array}{ll}119 \\
114\end{array}$ & & & & & & o. & 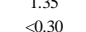 & 2.04 & $\begin{array}{l}1.11 \\
1.19\end{array}$ & 4.13 & 2.95 & 2.88 & 2.21 & $\begin{array}{l}2,39 \\
033\end{array}$ & 1.57 & 5.24 & $\begin{array}{l}4.68 \\
\text { (8) }\end{array}$ \\
\hline $\begin{array}{l}\text { To } \\
\text { Th }\end{array}$ & 0.063 & $\begin{array}{l}0.906 \\
0.065\end{array}$ & $\begin{array}{l}0.04 \\
0.059\end{array}$ & $\begin{array}{l}1.14 \\
0.059\end{array}$ & $\begin{array}{l}0.48 \\
0.024\end{array}$ & $<0.014$ & $\begin{array}{l}0.40 \\
<0.014\end{array}$ & $<0.014$ & $<0.014$ & $\begin{array}{l}<.014 \\
<0.014\end{array}$ & $<0.014$ & $\begin{array}{l}0.1215 \\
0.15\end{array}$ & $\begin{array}{l}1.199 \\
1.764\end{array}$ & 0.054 & 0.004 & 0.045 & 0.055 & 0.056 & $\begin{array}{l}0.1099 \\
0.19\end{array}$ & $\begin{array}{l}0.1 .15 \\
0\end{array}$ & $\begin{array}{l}0.85 \\
0.117\end{array}$ \\
\hline V. & $\begin{array}{l}0.029 \\
804\end{array}$ & 80 & $\begin{array}{l}0.030 \\
8809\end{array}$ & $\frac{0.043}{807}$ & 0.040 & 0.057 & 0.017 & 0.012 & 0.023 & 0.013 & 0.019 & 0.231 & $\frac{202}{602}$ & 0.062 & 0.071 & 0.065 & 0.104 & 0.100 & 0.122 & 0.127 & 0.171 \\
\hline
\end{tabular}




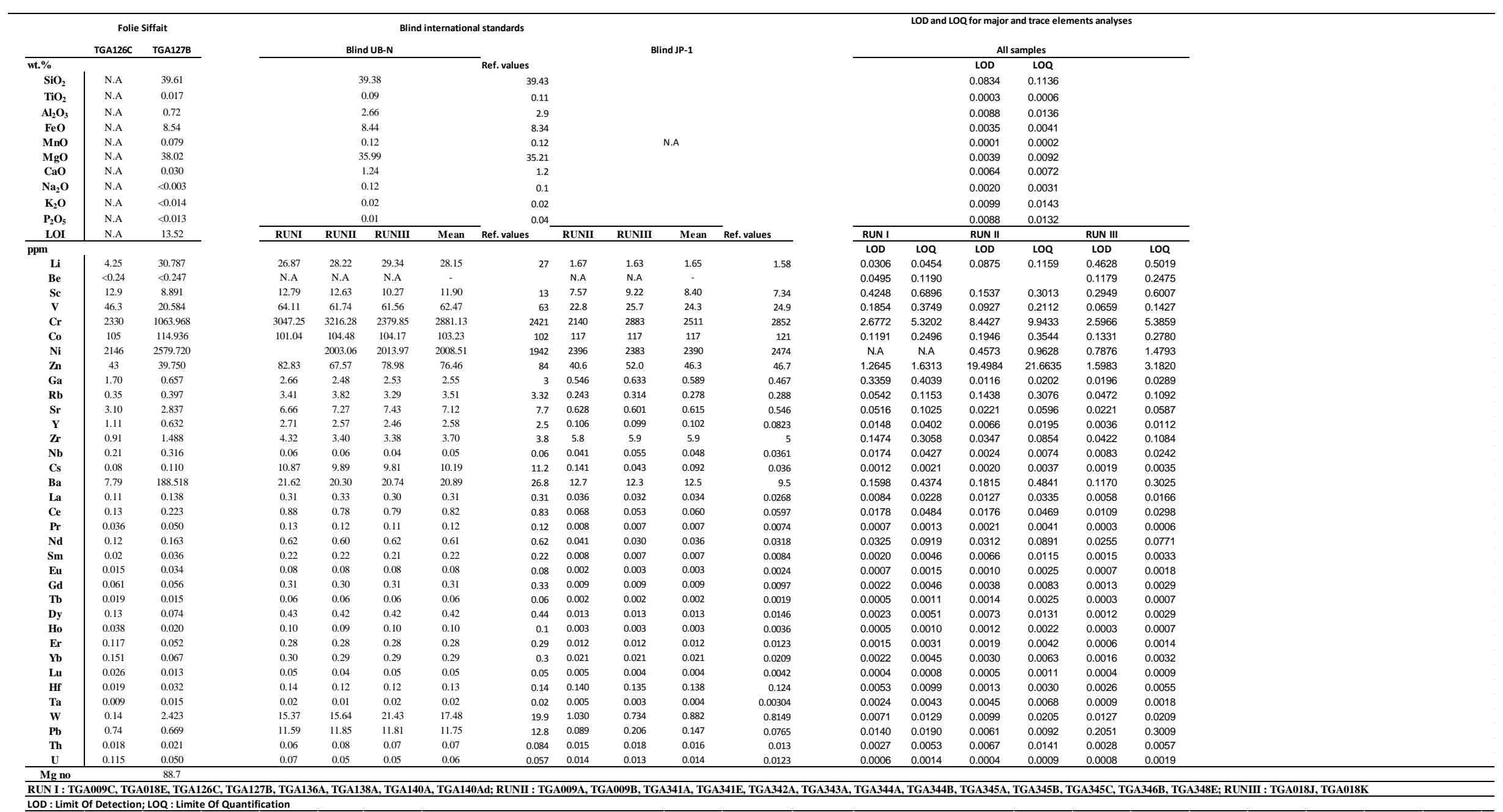


Table 5
Click here to download Table: Table 5.docx

\begin{tabular}{|c|c|c|c|c|c|c|c|c|c|c|c|c|c|c|c|}
\hline \multicolumn{16}{|c|}{ In-situ La-ICPMS analysis of pargasite (ppm) } \\
\hline $\begin{array}{l}\text { Locality } \\
\text { Sample name }\end{array}$ & 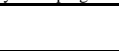 & & $\mathrm{TC}$ & $\begin{array}{l}\text { Pont de Barel } \\
07 \mathrm{C}\end{array}$ & & & \multicolumn{9}{|c|}{${ }_{\text {TGA346A-102 }}^{\text {Ty Lan }}$} \\
\hline & TGA007C-101 & TGA007C-102 & TGA007C-103 & TGA007C-104 & TGA007C-105 & TGA007C-106 & TGA346A-101 & TGA346A-102 & TGA346A-103 & TGA346A-104 & TGA346A-105 & TGA346A-106 & TGA346A-107 & TGA346A-108 & TGA346A-109 \\
\hline $\mathrm{Li}$ & 7.13 & 8.21 & 59.19 & 10.86 & 12.57 & 10.79 & 97.58 & 16.88 & 35.95 & 102.66 & 58.97 & 58.27 & 79.36 & 48.91 & 49.23 \\
\hline B & 13.27 & 24.97 & 85.74 & 48.23 & 58.77 & 41.19 & 11.64 & 18.5 & 21.93 & 17.78 & 22.56 & 22.73 & 4.58 & 5.7 & 12.24 \\
\hline $\mathrm{Ca}$ & 73655.12 & 72163.74 & 49501.99 & 60209.77 & 60296.47 & 64731.04 & 75927.86 & 62959.67 & 60210.96 & 71438.76 & 67833.02 & 58344.09 & 78612.14 & 81659.82 & 73079.06 \\
\hline Sc & 81.35 & 73.65 & 73.74 & 67.8 & & 82.49 & & 55.55 & 84.61 & & & 65.41 & & & \\
\hline Ti & 4309.7 & 4185.7 & 4097.26 & 3789.76 & 3997.34 & 4433.55 & 1014.68 & 462.48 & 828.87 & 860.25 & 866.36 & 809.05 & 932.34 & 1041.33 & 1047.06 \\
\hline $\mathrm{v}$ & 370.63 & 360.95 & 360.45 & 332.95 & 343.24 & 366.52 & 399.75 & 188.52 & 340.8 & 320.42 & 326.03 & 299.3 & 186.13 & 247.99 & 234.56 \\
\hline $\mathrm{Cr}$ & 4630.7 & 4804.16 & 5562.91 & 4175.15 & 4255.08 & 4480.88 & 8942.65 & 4577.58 & 7643.53 & 8812.52 & 870.42 & 8479.46 & 1116.17 & 4245.66 & 1569.55 \\
\hline Co & 40.09 & 38.15 & 52.52 & 54.63 & 52.44 & 46.78 & 47.03 & 40.5 & 35.31 & 42.26 & 47.24 & 55.96 & 34.49 & 31.85 & 36.25 \\
\hline $\mathrm{Ni}$ & 788.44 & 796.14 & 877.66 & 900.14 & 806.33 & 776.7 & 952.05 & 765.94 & 860.42 & 867.07 & 933.24 & 1004.1 & 943.23 & 864.45 & 919.84 \\
\hline $\mathrm{Cu}$ & 4.65 & 2.33 & 3.19 & 3.33 & 3.1 & 3 & 3.3 & 3.67 & 4.54 & 2.62 & 3.66 & 4.04 & 2.19 & 2.69 & 3.32 \\
\hline $\mathrm{Ca}$ & 4.3 & 4.37 & 4.04 & 4.22 & 3.97 & 3.85 & 6.12 & 2.82 & 4.49 & 6.24 & 5.36 & 5.12 & 9.25 & 8.54 & \\
\hline $\mathrm{Rb}$ & 3.13 & $\begin{array}{r}3.38 \\
18932\end{array}$ & 2.66 & 2.66 & 2.92 & 2.91 & 9.71 & 2.78 & 5.78 & 8.17 & 6.68 & 6.76 & 6.35 & 7.84 & 6.91 \\
\hline $\mathrm{Sr}$ & & 188.32 & 133.39 & 152.04 & 151.77 & 160.66 & 433.92 & 162.07 & 323.52 & 388.2 & 344.3 & 303.38 & 400.72 & 383.86 & 365.33 \\
\hline $\mathrm{Y}$ & 24.35 & 21.75 & 23.14 & 19.23 & 20.9 & 21.44 & 12.13 & 6.16 & 11.21 & 14.4 & 12.95 & 11.75 & 16.84 & 17.78 & 16.98 \\
\hline $\mathrm{Zr}$ & 17.5 & 16.2 & 16.82 & 15.09 & 16.07 & 17.98 & 21.17 & 8.89 & 15.97 & 26.07 & 23.58 & 21.19 & 48.38 & 36.32 & 40.86 \\
\hline $\mathrm{Nb}$ & 0.452 & 0.473 & 0.545 & 0.46 & 0.444 & 0.474 & 11.1 & 4.27 & 6.46 & 10.31 & 8.69 & 8.57 & 24.29 & 13.71 & 15.34 \\
\hline Mo & 0.088 & 0.08 & 0.304 & 0.059 & 0.191 & 0.135 & 0.189 & 0.264 & 0.061 & 0.099 & 0.105 & 0.131 & 0.053 & 0.057 & 0.055 \\
\hline Sn & 0.352 & 0.382 & 0.335 & 0.227 & 0.336 & 0.341 & 0.354 & 0.228 & 0.302 & 0.701 & 0.695 & 0.583 & 1.44 & 1.246 & 1.351 \\
\hline $\mathrm{Sb}$ & $<0.046$ & 0.092 & 0.072 & 0.056 & 0.13 & 0.285 & 0.668 & 0.566 & 0.262 & 0.328 & 0.225 & 0.246 & 0.578 & & \\
\hline Cs & 0.364 & 0.384 & 0.423 & 0.547 & 0.595 & 0.558 & 0.0844 & 0.162 & 0.204 & 0.13 & 0.1216 & 0.0949 & 0.0993 & 0.1463 & 1.001 \\
\hline Ba & 258.18 & 270.41 & 196.76 & 214.41 & 219.13 & 222.46 & 702.14 & 134.21 & 294.64 & 373.01 & 355.57 & 296.24 & 345.11 & 366.17 & 340.06 \\
\hline La & 6.06 & 6.37 & 6.3 & 5.34 & 5.51 & 5.49 & 35.5 & 10.56 & 21.05 & 37.11 & 20.07 & 21.45 & 49.83 & 35.57 & 34.6 \\
\hline $\mathrm{Ce}$ & 13.93 & 13.93 & 14.17 & 12.4 & 12.19 & 12.48 & 87.82 & 38.59 & 73.56 & 97.95 & 70.66 & 70.66 & 111.61 & 98.48 & 94.39 \\
\hline $\mathrm{Pr}$ & 1.311 & 1.297 & 1.315 & 1.121 & 1.134 & 1.175 & $\begin{array}{l}9.86 \\
3.309\end{array}$ & 5.37 & 9.93 & 12.04 & 9.6 & 9.41 & 12.94 & 12.5 & 12.04 \\
\hline $\begin{array}{ll}\mathrm{Nd} \\
\mathrm{Sm}\end{array}$ & $\begin{array}{l}4.82 \\
1.656\end{array}$ & $\begin{array}{l}4.66 \\
150\end{array}$ & $\begin{array}{l}4.72 \\
1563\end{array}$ & $\begin{array}{l}4.19 \\
1378\end{array}$ & $\begin{array}{l}4.08 \\
1566\end{array}$ & $\begin{array}{c}4.3 \\
1513\end{array}$ & $\begin{array}{l}33.93 \\
542\end{array}$ & $\begin{array}{l}21.16 \\
348\end{array}$ & $\begin{array}{l}38.28 \\
6.27\end{array}$ & $\begin{array}{l}45.93 \\
772\end{array}$ & $\begin{array}{l}37.44 \\
679\end{array}$ & 37.01 & 48.01 & 49.37 & 47.68 \\
\hline $\begin{array}{l}\begin{array}{l}\mathrm{Sm} \\
\mathrm{Eu}\end{array} \\
\mathrm{E}\end{array}$ & $\begin{array}{l}1.656 \\
0.663\end{array}$ & $\begin{array}{l}1.502 \\
0.669\end{array}$ & $\begin{array}{l}1.563 \\
0.635\end{array}$ & $\begin{array}{l}1.378 \\
0.554\end{array}$ & $\begin{array}{l}1.556 \\
0.579\end{array}$ & $\begin{array}{l}1.513 \\
0.613\end{array}$ & $\begin{array}{l}5.42 \\
1.566\end{array}$ & $\begin{array}{c}3.48 \\
0.852\end{array}$ & $\begin{array}{l}6.27 \\
1.63\end{array}$ & $\begin{array}{l}7.72 \\
208\end{array}$ & $\begin{array}{r}6.79 \\
1816\end{array}$ & $\begin{array}{l}6.61 \\
1.686\end{array}$ & $\begin{array}{l}8.52 \\
23\end{array}$ & $\begin{array}{l}9.37 \\
.36\end{array}$ & 8.93 \\
\hline $\begin{array}{l}\mathrm{Bu} \\
\mathrm{Gd}\end{array}$ & $\begin{array}{l}0.663 \\
2.78\end{array}$ & $\begin{array}{l}0.669 \\
2.59\end{array}$ & $\begin{array}{l}0.635 \\
2.79\end{array}$ & $\begin{array}{l}0.0554 \\
2.337\end{array}$ & $\begin{array}{l}0.579 \\
2.48\end{array}$ & $\begin{array}{l}0.613 \\
2.52\end{array}$ & $\begin{array}{l}1.566 \\
3.69\end{array}$ & $\begin{array}{l}0.852 \\
2.238\end{array}$ & $\begin{array}{l}1.603 \\
3.91\end{array}$ & $\begin{array}{l}2.08 \\
5.02\end{array}$ & $\begin{array}{l}1.816 \\
4.52\end{array}$ & $\begin{array}{l}1.686 \\
4.27\end{array}$ & $\begin{array}{l}2.3 \\
628\end{array}$ & $\begin{array}{l}2.36 \\
6.59\end{array}$ & $\begin{array}{l}2.29 \\
635\end{array}$ \\
\hline $\mathrm{Tb}$ & 0.56 & 0.495 & 0.535 & 0.437 & 0.482 & 0.488 & 0.445 & $\begin{array}{l}.2 .288 \\
0.254\end{array}$ & $\begin{array}{l}3.91 \\
0.466\end{array}$ & $\begin{array}{l}.0 .22 \\
0.593\end{array}$ & $\begin{array}{l}4.52 \\
0.536\end{array}$ & $\begin{array}{l}4.27 \\
0.499\end{array}$ & $\begin{array}{l}\begin{array}{l}6.88 \\
0.739\end{array} \\
0\end{array}$ & $\begin{array}{l}0.59 \\
0.766\end{array}$ & $\begin{array}{l}\begin{array}{l}6.33 \\
0.741\end{array} \\
0\end{array}$ \\
\hline Dy & 3.93 & 3.63 & 3.78 & 3.23 & 3.44 & 3.57 & 2.317 & 1.225 & 2.184 & 2.86 & 2.57 & 2.42 & 3.5 & 3.66 & 3.49 \\
\hline Но & 0.904 & 0.827 & 0.882 & 0.742 & 0.796 & 0.798 & 0.428 & 0.2175 & 0.4 & 0.497 & 0.463 & 0.421 & 0.577 & 0.632 & 0.618 \\
\hline Er & 2.8 & 2.513 & 2.7 & 2.186 & 2.379 & 2.463 & 1.235 & 0.553 & 1.075 & 1.294 & 1.219 & 1.105 & 1.53 & 1.002 & 1.558 \\
\hline $\mathrm{Tm}$ & 0.406 & 0.373 & 0.387 & 0.317 & 0.346 & 0.37 & 0.1827 & 0.0754 & 0.1517 & 0.1877 & 0.1634 & 0.147 & 0.202 & 0.213 & 0.213 \\
\hline $\mathrm{Yb}$ & 2.81 & 2.588 & 2.75 & 2.311 & 2.485 & 2.543 & 1.211 & 0.582 & 1.07 & 1.264 & 1.14 & 1.085 & 1.351 & 1.477 & 1.377 \\
\hline Lu & 0.409 & 0.383 & 0.404 & 0.334 & 0.358 & 0.369 & 0.1877 & 0.0828 & 0.1644 & 0.19 & 0.1785 & 0.1626 & 0.1977 & 0.215 & 0.2012 \\
\hline Hf & 0.818 & 0.786 & 0.788 & 0.712 & 0.777 & 0.869 & 0.446 & 0.238 & 0.419 & 0.89 & 0.892 & 0.796 & 2.88 & 1.91 & 2.35 \\
\hline Та & 0.0251 & 0.0275 & 0.0351 & 0.0251 & 0.023 & 0.0238 & 0.31 & 0.1367 & 0.256 & 0.515 & 0.423 & 0.438 & 1.954 & 0.865 & 1.238 \\
\hline w & 0.0227 & 0.0074 & 0.0212 & 0.0186 & 0.0118 & 0.0077 & 1.852 & 3.67 & 0.212 & 0.0525 & 0.0601 & 0.0924 & 0.0052 & 0.0055 & 0.464 \\
\hline $\mathrm{Tl}$ & 0.0697 & 0.0498 & 0.0452 & 0.1099 & 0.0427 & 0.0435 & 0.285 & 0.0848 & 0.1544 & 0.215 & 0.173 & 0.17 & 0.193 & 0.187 & 0.178 \\
\hline $\mathrm{Pb}$ & $\begin{array}{c}4.64 \\
0.578\end{array}$ & $\begin{array}{l}4.61 \\
0.622\end{array}$ & $\begin{array}{l}4.34 \\
0.357\end{array}$ & $\begin{array}{l}3.76 \\
0.232\end{array}$ & 3.92 & $\begin{array}{l}4.2 \\
0.137\end{array}$ & $\begin{array}{l}18.38 \\
446\end{array}$ & $\begin{array}{l}6.26 \\
0.324\end{array}$ & $\begin{array}{l}10.95 \\
0.982\end{array}$ & $\begin{array}{l}17.3 \\
1701\end{array}$ & $\begin{array}{l}12.43 \\
0554\end{array}$ & 12.47 & 15.32 & $\begin{array}{l}13.8 \\
0.62\end{array}$ & 12.6 \\
\hline $\begin{array}{l}\text { Th } \\
\text { U }\end{array}$ & $\begin{array}{l}0.1578 \\
0.0705\end{array}$ & $\begin{array}{l}0.232 \\
0.1139\end{array}$ & $\begin{array}{l}0.357 \\
0.2001\end{array}$ & $\begin{array}{l}0.322 \\
0.1166\end{array}$ & $\begin{array}{l}0.25 \\
0.1213\end{array}$ & $\begin{array}{l}0.0137 \\
0.0501\end{array}$ & $\begin{array}{l}4.46 \\
1.529\end{array}$ & $\begin{array}{l}0.344 \\
0.0818\end{array}$ & $\begin{array}{l}0.0882 \\
0.1835\end{array}$ & $\begin{array}{l}1.701 \\
0.296\end{array}$ & $\begin{array}{l}0.0584 \\
0.1776\end{array}$ & $\begin{array}{l}1.106 \\
0.261\end{array}$ & $\begin{array}{l}2.98 \\
0.842\end{array}$ & $\begin{array}{l}0.62 \\
0.229\end{array}$ & $\begin{array}{l}10.91 \\
0.404\end{array}$ \\
\hline entrat & $\begin{array}{l}\text { Iculated usin } \\
\text { s. }\end{array}$ & $\begin{array}{l}\text { offilwareTM } \\
\text { oflas }\end{array}$ & 0.2001 & 0.1166 & 0.1215 & & & & 0.1833 & 0.296 & 0.1776 & 0.261 & & & 0.404 \\
\hline
\end{tabular}

